Faculdade de Zootecnia e Engenharia de Al iment os

\title{
EXIGÊNCIAS DE PROTEÍNA E ENERGIA LÍQUIDAS PARA O GANHO DE PESO DE TOURINHOS DAS RAÇAS NELORE E BRANGUS ALIMENTADOS COM DIETAS COM DIFERENTES PROPORÇÕES DE CONCENTRADO
}

\section{SORAIA MARQUES PUTRINO}

Dissertação de Mestrado depositada na Seção de Pós-Graduação da Faculdade de Zootecnia e Engenharia de Alimentos da USP, como parte dos requisitos para a obtenção do Título de Mestre em Zootecnia, na área de Concentração: Qualidade e Produtividade Animal.

Orientador: Prof.Dr. Paulo Roberto Leme 


\section{FICHA CATALOGRÁFICA}

preparada pela

Biblioteca da Faculdade de Zootecnia e Engenharia de Alimentos da Universidade de São Paulo

\section{Putrino, Soraia Marques.}

P988e Exigências de proteína e energia líquidas para o ganho de peso de tourinhos das raças Nelore e Brangus alimentados com dietas com diferentes proporções de concentrado / exemplar revisado e alterado em relação a versão original, sob a exclusiva responsabilidade do autor. Soraia Marques Putrino. Pirassununga, 2002.

$75 \mathrm{p}$.

Dissertação (Mestrado) -- Faculdade de Zootecnia e

Engenharia de Alimentos - Universidade de São Paulo.

Departamento de Zootecnia.

Unitermos: 1. Bovinos, composição corporal

2. Bovinos, raça, Brangus 3. Bovinos, raça, Nelore

4. Nutrição Animal, bovinos I. Título. 
"Vitorioso não é aquele que vence os outros, mas o que vence a si mesmo, dominando seus vícios e superando seus defeitos. A vitória sobre si mesmo é muito mais difícil, e quem consegue isto pode ser classificado como verdadeiro herói."

Autor desconhecido 
Dedico, com muito amor...

Aos meus pais, Orlando e Inez, verdadeiros amigos e a quem tanto amo, que sempre souberam o momento certo de pronunciar palavras de estímulo e nunca mediram esforços para me ajudar.

Aos meus queridos irmãos, Fernando e Sara, pelo companheirismo e disposição para me ajudar em todos os momentos que precisei.

À Tami, Shiva, Fani e Félix, que me alegram todos os dias e em qualquer circunstância. 
Dedico, com amor e carinho...

Ao Carlos Grossklaus, que sempre demonstrou muito amor e me confortou nos momentos difíceis que passei. 


\section{AGRADEÇO}

Aos meus pais, por simplesmente serem os meus pais...

Aos meus irmãos e ao Carlinhos, por sempre estarem presente na minha vida.

Ao Prof. Dr. Paulo Roberto Leme, por ter me estimulado a cursar o mestrado, pela orientação, ensinamentos, amizade o os bons momentos de trabalho em conjunto.

Aos professores César Gonçalves de Lima e Catarina Abdalla Gomide, dispostos a ajudar em todos os momentos que precisei.

Ao pesquisador Guilherme Fernando Alleoni pela ajuda imprescindível na análise das amostras e amizade.

Ao professor Dante Pazzanese Duarte Lanna pelos ensinamentos e amizade. Aos funcionários Adalberto, Fernandinho, Fernando Schalch, Ismael, Paulinho, Ricardo, Tião, e todos os outros que de alguma forma contribuíram para que este projeto fosse realizado.

Aos funcionários de laboratório Cunha, Mozambinho, Rafael, Rose, Rosilda e Silvana, pela enorme ajuda que me deram.

A todos estagiários que trabalharam em alguma atividade deste projeto.

À Faculdade de Zootecnia e Engenharia de Alimentos, pela minha formação.

À FAPESP, pelo apoio financeiro ao projeto.

Aos professores Jacinta e Valdo, sempre com suas presenças amigas.

Aos amigos Juliana, Arlindo, Márcia, Angélica e Saulo pela amizade e ajuda.

À minha avó, tios e primos pela amizade.

A Deus, por tudo... 


\section{ÍNDICE}

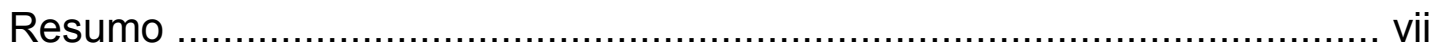

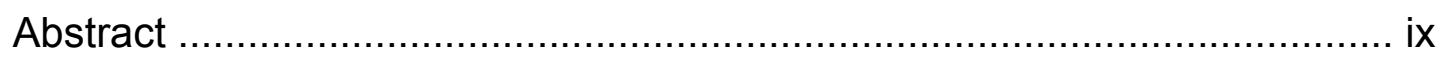

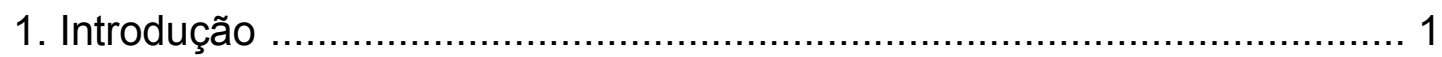

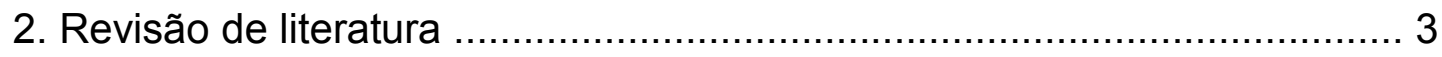

2.1. A raça Nelore .................................................................. 3

2.2. A raça Brangus ................................................................ 5

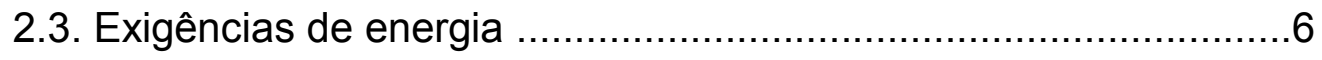

2.4. Exigências de proteína ....................................................... 10

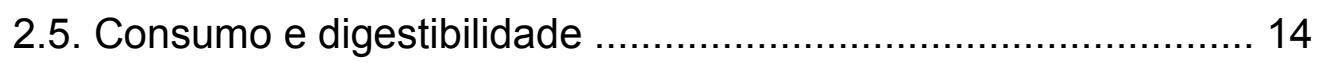

2.6. Composição corporal e ganho de peso …………………......... 17

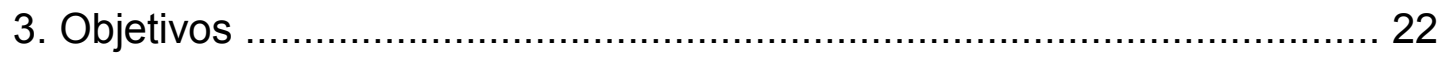

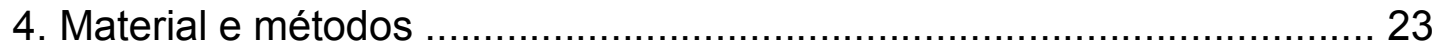

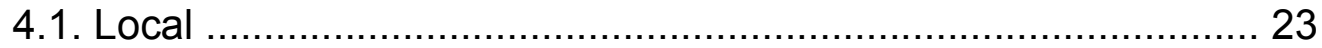

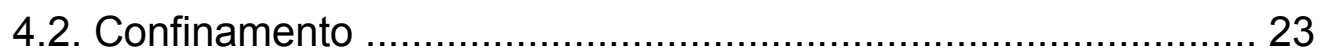

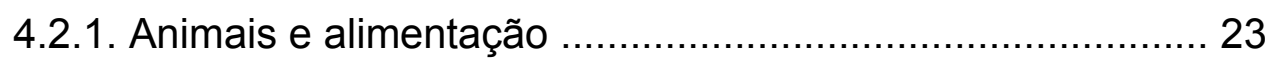

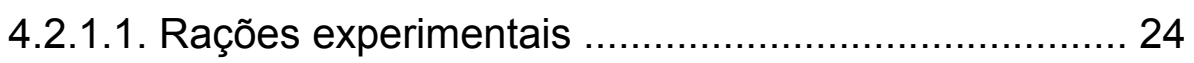

4.2.1.2. Análises bromatológicas das rações ........................ 24

4.2.2. Análises de glicose no plasma sanguíneo ......................... 25

4.2.3. Análises de uréia no soro sanguíneo …………................. 25

4.3. Abate e composição corporal ................................................ 26

4.3.1. Estimativa do peso vazio (PCVz) …………….............. 26

4.3.2. Corte da $9-10-11^{a}$ costelas .............................................. 27

4.3.3. Estimativa da porcentagem de água e gordura no corpo vazio $(\mathrm{CVz})$............................................ 28

4.4. Estimativa da energia líquida depositada ................................ 29

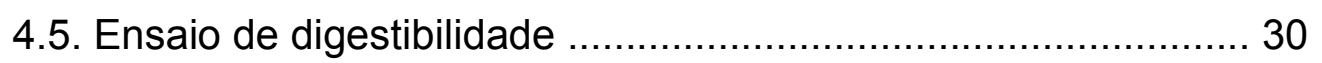

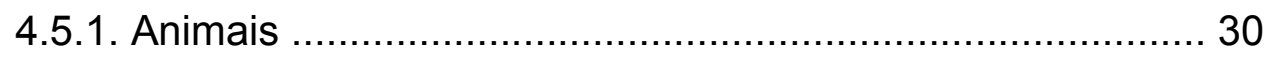

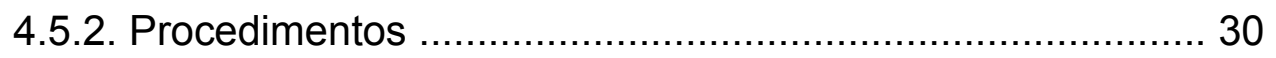

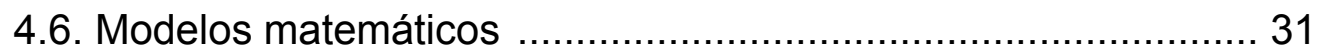

4.6.1. Delineamento experimental do confinamento .................... 31 
4.6.2. Delineamento experimental do ensaio de digestibilidade ................................................... 31

4.6.3. Desempenho animal e características de carcaça ............. 31

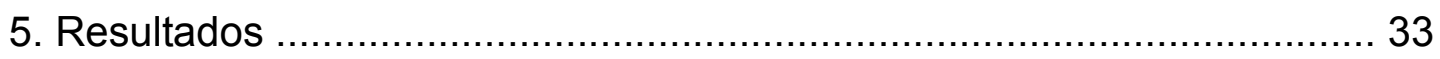

5.1. Ensaio de digestibilidade..................................................... 33

5.2. Análises de glicose no plasma sanguíneo ……......................... 40

5.3. Análises de uréia no soro sanguíneo ..................................... 40

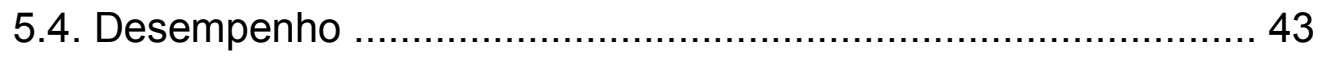

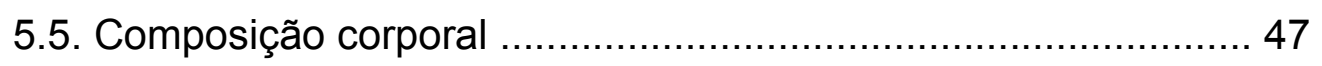

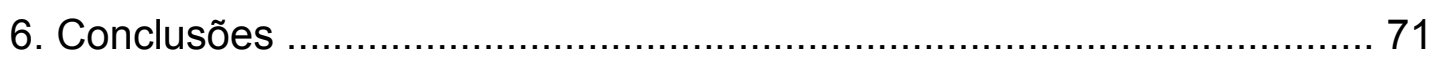

7. Referências bibliográficas .............................................................. 73 


\section{LISTA DE TABELAS}

Tabela 1. Ingredientes das rações experimentais 24

Tabela 2. Análises bromatológicas das rações experimentais 25

Tabela 3. Coeficientes de digestibilidade dos nutrientes, nutrientes digestíveis totais, energia digestível, energia metabolizável e consumo de MS das dietas experimentais para animais Brangus e Nelore. 35

Tabela 4. Equações de regressão dos coeficientes de digestibilidade dos nutrientes e teores de NDT, \% de consumo de MS, ED e EM para as raças Brangus e Nelore em função do nível de concentrado na dieta

Tabela 5. Peso vivo em jejum, peso vazio, peso de carcaça quente, ganhos de peso e composição dos cortes da 9-10-11 a costelas

Tabela 6. Composição química do corpo vazio dos animais no início e no final do experimento 50

Tabela 7. Taxa de deposição dos componentes químicos corporais e composição do ganho do peso vazio

Tabela 8. Equações de regressão dos parâmetros de composição corporal para as raças Brangus e Nelore em função do nível de concentrado na dieta 61

Tabela 9. Correlação entre a composição do corpo vazio (CVz) e a composição do ganho de peso vazio (GPVz)... 62 


\section{LISTA DE GRÁFICOS E FIGURAS}

Gráfico 1. Valores de glicose sanguínea dos animais

Gráfico 2. Valores de nitrogênio originário da uréia sanguínea (NUS) dos animais

Gráfico 3. Ganho de peso em jejum diário dos animais

Gráfico 4. Porcentagem de ingestão de matéria seca diária em função do peso vivo dos animais

Gráfico 5. Eficiência alimentar dos animais

Gráfico 6. Concentração de proteína em gramas por kg de GPVz em função dos níveis de concentrado na dieta

Gráfico 7. Concentração de energia em Mcal por kg de GPVz em

função dos níveis de concentrado na dieta 53

Gráfico 8. Exigências líquidas de proteína $(\mathrm{kg})$ por kg de GPVz, em função do $\mathrm{PCV} z(\mathrm{~kg})$

Gráfico 9. Ganho de gordura (kg) por kg de GPVz, em função do PCVz (kg) 55

Gráfico 10. Exigências líquidas de energia (Mcal) por kg de GPVz em função do $\mathrm{PCV} z(\mathrm{~kg})$ 56

Gráfico 11. GPJ, GPVz, GPCQ dos animais das raças Brangus e Nelore em função dos níveis de concentrado na dieta 58

Gráfico 12. Relações entre o GPJ, GPVz e GPCQ de tourinhos da raça Brangus alimentados com diferentes proporções de concentrado na dieta

Gráfico 13. Relações entre o GPJ, GPVz e GPCQ de tourinhos da raça Nelore alimentados com diferentes proporções de concentrado na dieta. 59

Gráfico 14. GPJ, GPVz e GPCQ em relação ao tratamento de $20 \%$ de concentrado na dieta para animais da raça Brangus

Gráfico 15. GPJ, GPVz e GPCQ em relação ao tratamento de $20 \%$ de concentrado na dieta para animais da raça Nelore 60

Gráfico 16. GPCQ em porcentagem do GPJ nos diferentes tratamentos para animais das raças Brangus e Nelore 60 
Figura 1. Vista da secção da 9-10-11 ${ }^{\text {a }}$ costelas através de um corte perpendicular a coluna dorsal na altura da $12^{\mathrm{a}}$ costela 27 


\section{LISTA DE ABREVIATURAS}

${ }^{\circ} \mathrm{C}$ : graus Celsius

$\mathrm{CH}$ 4: metano

CO2: gás carbônico

CVz: corpo vazio

dl: decilitros

EB: energia bruta

ED: energia digestível

EE: extrato etéreo

EM: energia metabolizável

ENN: extrativo não-nitrogenado

ER: energia retida

F1: primeira geração do cruzamento entre raças

FB: fibra bruta

FDA: fibra em detergente ácido

FDN: fibra em detergente neutro

g: grama

GPCQ: ganho de peso de carcaça quente

GPJ: ganho de peso em jejum

GPVz: ganho de peso vazio

$\mathrm{H} 2 \mathrm{O}$ : água

Kcal: quilocalorias

kg: quilogramas

Mcal: mega calorias

mg: miligrama

$\mathrm{mm}$ : milímetros

MM: matéria mineral

MO: matéria orgânica

MS: matéria seca

$\mathbf{N}$ : nitrogênio, nitrogenado

NDT: nutrientes digestíveis totais

NUS: nitrogênio uréico sanguíneo

NUP: nitrogênio uréico plasmático

PB: proteína bruta

PCQ: peso da carcaça quente

PCVz: peso corporal vazio

PDR: proteína degradável no rúmen

Ph: potencial hidrogeniônico

PJ: peso em jejum

PM: proteína metabolizável

PMIVd: proteína microbiana verdadeira degradável

PNDR: proteína não degradável no rúmen

PNDRd: proteína não degradável no rúmen digestível PV $^{0,75}$ : peso metabólico

®: marca registrada

rpm: rotações por minuto 


\section{RESUMO}

O conhecimento das exigências de proteína e energia para o ganho de peso e para a mantença dos bovinos de corte é importante para se obter produtividade máxima com custo mínimo. A raça Nelore compõe grande parte do rebanho brasileiro, e a raça Brangus vem sendo muito utilizada como produto de cruzamento entre uma raça zebuína e taurina (Nelore e Angus). Porém, para a alimentação destes animais são utilizados dados de exigências nutricionais gerados na Europa e Estados Unidos, obtidos com animais e ambientes diferentes dos encontrados no Brasil. Os objetivos deste trabalho foram estimar as exigências de proteína e energia para o ganho de peso de animais das raças Brangus e Nelore através da técnica de abates comparativos. Para isso estimou-se o ganho e a composição corporal através do corte da $9-10-11^{\text {a }}$ costelas de animais destas raças, alimentados com diferentes proporções de concentrado. A ingestão e a digestibilidade das dietas também foram avaliadas. Utilizou-se 56 bovinos machos inteiros, 28 de cada raça, com idade média de 8 meses e peso médio de $212 \mathrm{~kg}$ no início experimento. Quatro animais de cada raça foram abatidos no início do período experimental para a estimativa da composição corporal inicial. Os outros animais foram confinados em baias coletivas (doze animais por baia, com alimentação individual através de portões eletrônicos Calan) e alimentados com rações experimentais com 20, 40, 60 e $80 \%$ de concentrado na matéria seca. As pesagens foram realizadas em intervalos de 28 dias após jejum completo de 18 horas, e o período de confinamento foi de 145 dias. O peso médio final foi de $400 \mathrm{~kg}$ para a raça Brangus e $361 \mathrm{~kg}$ para a raça Nelore. O delineamento experimental foi inteiramente casualizado em arranjo fatorial $2 \times 4$. $O$ ensaio de digestibilidade foi realizado com quatro animais de cada raça, alojados em gaiolas de metabolismo, com coleta total de fezes. O delineamento foi em quadrado latino. Os ganhos diários de peso vivo em jejum, de peso vazio e de peso de carcaça quente foram diferentes entre as raças com os maiores ganhos para a raça Brangus 
e níveis de concentrado na dieta. As maiores médias para as raças Brangus e Nelore foram obtidas com $40 \%$ e $60 \%$ de concentrado na dieta, respectivamente. Os coeficientes de digestibilidade da proteína bruta e da matéria mineral foram diferentes entre raças $(P<0,01)$, com as maiores médias para a raça Brangus. $O$ teor de nutrientes digestíveis totais foi diferente entre raças $((\mathrm{P}<0,09)$, com as maiores médias para a raça Nelore $)$ e entre níveis de concentrado na dieta. Os coeficientes de digestibilidade da fibra bruta e da fibra em detergente neutro, os teores de energia digestível e metabolizável foram diferentes entre as proporções de concentrado na dieta $(P<0,01)$. Os tratamentos com $20 \%$ e $40 \%$ de concentrado apresentaram maiores médias para a digestibilidade da fibra em detergente neutro e fibra bruta, respectivamente. $\mathrm{O}$ tratamento com $80 \%$ de concentrado apresentou maiores médias para os teores de nutrientes digestíveis totais, energia digestível e metabolizável. As composições do corpo vazio e do ganho de peso vazio foram diferentes entre raças. A raça Brangus apresentou as maiores médias de extrato etéreo e energia e a Nelore as maiores médias de água, proteína e cinzas. As exigências líquidas de proteína e de energia para o ganho de peso vazio foram diferentes entre raças, com valores médios para o Brangus e o Nelore de, respectivamente, 0,160 e 0,188 kg de proteína e 3,02 e 2,66 Mcal por kg de ganho de peso vazio. De acordo com estes resultados foi possível observar que a raça Brangus apresentou maior deposição de gordura do que o Nelore. Não foram observadas diferenças entre os níveis de concentrado na dieta, provavelmente devido à idade jovem dos animais que não alcançaram a fase de maior deposição de gordura da curva de crescimento. 


\begin{abstract}
The determination of energy and protein requirements for maintenance and growth of beef cattle is very important for an efficient animal production. Nellore and crossed breeds like Brangus are very used in Brazil, but the main source of information about nutritional requirements is the NRC, whose data was obtained with different breeds and environments. The objective of this experiment was to determine the energy and protein requirements of Brangus and Nellore bulls through the comparative slaughter technique, with body and gain composition estimated from the 9-10-11a rib cut of these breeds fed diets with different concentrate proportions. The fed intake and digestibility of these diets were also determined. Fifty-six young bulls were utilized, 28 of each breed, with $212 \mathrm{~kg}$ of shrunk body weight and 8 months of age. Four Brangus and four Nellore bulls were slaughtered in the beginning of the experiment to estimate the initial body composition. The other animals were fed diets with increasing levels of concentrate $(20,40,60$ and $80 \%$ of the dry matter). The animals were weighted at 28 days intervals and the daily feed intake individually controlled through Calan Gate equipment. After 145 days of feeding the animals were slaughtered. A completely randomized design with factorial arrangement (2X4) was utilized. Four animals of each breed were utilized in a digestibility trial with total feces collection. The experimental design was the Latin square. The shrunk body gain, empty body gain and hot carcass gain were different for breeds $(P<0,01)$, and for concentrate levels $(P<0,01)$. The Brangus animals were heavier than the Nellore. The Brangus and Nellore breeds showed the best performance with $40 \%$ and $60 \%$ concentrate diets, respectively. The digestibility of the crude protein and mineral matter was different for breeds $(P<0,02)$, and the Brangus bulls were heavier than the Nellore. The total digestible nutrients also was different for breeds $((P<0,09)$ the Nellore bulls showed the greatest means), and for concentrate levels $(P<0,01)$. The digestibility of crude fiber and neutral detergent fiber, digestible and metabolizable energy of the diets was different for concentrate levels
\end{abstract}


$(P<0,01)$. The $20 \%$ and $40 \%$ concentrate diets showed the best crude fiber and neutral detergent fiber digestibility, respectively. The $80 \%$ concentrate diet showed the best total digestible nutrients, digestible and metabolizable energy. Fat and energy values in the empty body weight gain were greatest $(P<0,01)$ for Brangus bulls and water, protein and ashes were greatest $(P<0,01)$ for Nellore bulls. Protein and energy requirements for growth were different $(P<0,01)$ for breeds, with values of 0.160 and $0.188 \mathrm{~kg}$ of protein and 3.02 and $2.66 \mathrm{Mcal}$ of energy per $\mathrm{kg}$ of empty body gain, respectively for Brangus and Nelore bulls. These results showed that Brangus had greater net energy requirement for gain than Nellore. Probably the effect of concentrate levels was not expressive because the animals were young and had not reached the phase of higher fat deposition of the growth curve. 


\section{INTRODUÇÃO}

Para que seja possível obter produtividade máxima com custo mínimo, é necessário que se conheça as exigências de energia para a mantença e para o ganho de peso de bovinos.

A maior parte do rebanho brasileiro é constituída de zebuínos, principalmente da raça Nelore, que apresentam boa adaptação às condições ambientais, porém produtividade inferior a outros genótipos principalmente em função de um manejo nutricional deficiente. Esses índices de produtividade podem ser alterados através de mudanças nas condições ambientais e na composição genética dos animais. Dentre os fatores ambientais, o suprimento das exigências nutricionais específicas de cada raça é de extrema importância, já que nos sistemas de produção de gado de corte brasileiro vêm sendo utilizados dados de tabelas gerados na Europa ou nos Estados Unidos (ARC, NRC), obtidos com animais e ambientes diferentes. Quanto à mudança na composição genética, nos últimos anos, a pecuária de corte no Brasil tem experimentado mudanças profundas, principalmente pela utilização de raças sintéticas ou produtos de cruzamentos de animais de raças zebuínas e européias, as quais, em sistemas intensivos de produção, proporcionam altos índices de produtividade. Dentre essas raças, a Brangus, produto do cruzamento de animais Angus e Nelore, tem sido amplamente utilizada, em regime de confinamento, sem que sejam conhecidas suas exigências nutricionais nas nossas condições.

Muitos trabalhos estudam o desempenho de bovinos confinados, entretanto, apenas alguns se referem à eficiência de utilização de energia e proteína para o ganho de peso e às taxas de deposição dos componentes 
químicos (proteína, extrato etéreo e matéria mineral) para diferentes taxas de ganho de peso. 


\section{REVISÃO DE LITERATURA}

\subsection{A raça Nelore}

O Brasil possui cerca de 161,8 milhões de cabeças de bovinos, incluindo gado de corte, de leite e de dupla aptidão. O rebanho de bovinos para corte é de aproximadamente 117,8 milhões de cabeças (ANUALPEC, 2001). Estima-se que $80 \%$ do rebanho de corte seja de zebuínos ou animais cruzados com zebu.

O primeiro registro de Nelore (Bos taurus indicus) no Brasil data de 1868, quando um casal da raça estava a bordo de um navio com destino à Inglaterra (presente de um príncipe indiano à Rainha Vitória), e por ordem de um representante consular inglês foi desembarcado e vendido em território brasileiro (SANTIAGO, 1983).

A raça Nelore se expandiu aos poucos pelo país, entrando primeiro pelos estados do Rio de Janeiro e Bahia e em seguida no triângulo Mineiro. O Estado de São Paulo foi o último a aderir à criação de zebuínos. A última importação ocorreu em 1962, trazendo touros que contribuíram para a formação da base do rebanho brasileiro (VIACAVA et al., 2000).

A raça Nelore, bastante adaptada às condições tropicais, se expandiu por todo território brasileiro, alcançando uma alta proporção em termos de rebanho. Segundo PINEDA (2000), esta grande expansão se deve às características da raça, em termos de fertilidade, rusticidade, adaptabilidade ao ambiente tropical e adequação a um sistema de produção extensivo.

Quanto à qualidade de carcaça, o novilho Nelore apresenta padronização dos cortes cárneos e espessura mínima de gordura subcutânea necessária, dificilmente encontrada nas raças taurinas continentais e seus cruzamentos. Já as carcaças de novilhos precoces cruzados, têm apresentado grandes diferenças de peso de um lote para 
outro e geralmente apresentando deficiências na gordura de cobertura (FELÍCIO, 1999).

O peso das carcaças dos animais abatidos no Brasil Central tem melhorado substancialmente nos últimos anos (PINEDA, 2000). Segundo PARDI et al. (1996), em 70 anos, o peso médio das carcaças de 7,4 milhões de zebuínos abatidos em um único frigorífico, passou de 234,5 kg para 268,6 $\mathrm{kg}$ (aumento correspondente a 12\%). Neste mesmo período, o rendimento de carcaça em relação ao peso vivo melhorou 4,2\%. Estes autores afirmam que entre 1968 e 1985, as carcaças do gado Gir aumentaram 2,8 kg enquanto que as de gado Nelore aumentaram 6,9 kg. E de 1992 a 1994, a diferença para o gado Nelore foi de 18,6 kg. Assim, a utilização de animais da raça Nelore na produção de gado comercial brasileiro melhorou a produção nacional de carne (PINEDA, 2000).

Segundo BARBOSA (1999), o uso da seleção em gado zebu proporciona resultados comparáveis à estratégia de cruzamentos para produção de novilhos precoces quanto ao peso, idade de abate e espessura de gordura.

Tem sido demonstrado que o Bos taurus indicus tem menores necessidades de mantença que o Bos taurus taurus (FRISCH e VERCOE, 1977; TAYLOR et al., 1986), o que the daria vantagens em momentos de escassez de alimento, por exemplo, durante a estação seca.

No Brasil, SALVADOR et al. (1981) obteve, para novilhos azebuados, exigência de energia para mantença de $56 \mathrm{kcal} / \mathrm{kg}$ 0,75/dia. Trabalhando com animais da raça Nelore PIRES et al. (1993b) e FREITAS (1995) encontraram valores de 59,8; 34,2 e 50,2 kcal $/ \mathrm{kg}$ 0,75/dia, respectivamente.

$\mathrm{Na}$ literatura, são encontrados resultados negativos para zebuínos alimentados com dietas ricas em concentrado. MOORE et al. (1975) observaram maiores coeficientes de digestibilidade da matéria seca para zebuínos em relação aos taurinos, ao utilizarem rações com alta proporção de volumosos, enquanto LEDGER et al. (1970) concluíram que os taurinos, alimentados à vontade com rações ricas em concentrado, eram mais eficientes que os zebuínos. 


\subsection{A raça Brangus}

A busca por uma raça que apresentasse altos índices de produção associados à adaptação às duras condições de clima e meio ambiente de regiões tropicais e subtropicais levaram pesquisadores americanos e brasileiros a iniciarem trabalhos de cruzamento controlados, envolvendo raças européias e zebuínas (MACIEL, 2000).

Especificamente nos EUA, as raças Angus e Brahman começaram a ser cruzadas na Louisiana a partir de 1912, originando o programa Brangus, que finalmente em 1949, com a fundação da associação de criadores, foi reconhecida como raça definida pelo governo americano (MACIEL, 2000).

No Brasil, trabalho similar de cruzamento, utilizando as raças Angus e Nelore, foi desenvolvido por técnicos do Ministério da Agricultura em Bagé, em fase experimental a partir de 1940, recebendo em 1955 a classificação de trabalho preferencial. Em 1989, transforma-se em Associação Brasileira de Brangus Ibagé, com a aceitação do Brangus no registro genealógico (MACIEL, 2000).

O Brangus é considerado um animal de raça sintética, bimestiço formado por $5 / 8$ (ou $62,5 \%$ ) de sangue Angus e $3 / 8$ (ou 37,5\%) de sangue Zebu. Neste cruzamento, procura-se a interação entre a rusticidade, tolerância ao calor, fertilidade, longevidade e resistência a infestações de ectoparasitas (berne e carrapato) do Zebu, com a fertilidade, habilidade materna, precocidade e excelentes qualidades de carcaça e carne dos Angus. Atualmente, o rebanho ativo do Brasil é de aproximadamente 50 mil fêmeas registradas (MACIEL, 2000).

O cruzamento utilizando a raça Brangus, promove encurtamento do ciclo de produção. Na média, em regime extensivo, o criador ganha um ano no início da vida reprodutiva das novilhas (aos $320 \mathrm{~kg}$ ) e na idade de abate dos machos (aos $489 \mathrm{~kg}$ ) em relação ao que se vinha conseguindo com os puros zebuínos (MACIEL, 2000).

O BETTER BEEF BUSINES, citado por MACIEL (2000), comparou o Brangus com as raças Angus, Pardo-Suíço, Charolês, Chianina, Limousin, Red Poll, Santa Gertrudis e Simental. O Brangus apresentou maior eficiência 
em condições mínimas de manejo, maior fertilidade, boa habilidade materna (ficou inferior somente em relação ao Angus). Os bezerros apresentam tamanho médio, o peso ótimo para abate é de $469 \mathrm{~kg}$, e quanto à musculatura apresentou índices pouco inferiores ao do Angus. É uma raça indicada para cruzamento maternal e rotacional.

\subsection{Exigências de energia}

Nas últimas décadas, inúmeros pesquisadores conduziram trabalhos de pesquisa visando à determinação das exigências de energia para bovinos de corte, com o objetivo de diminuir os custos da produção de carne através da utilização de rações de custo mínimo. No entanto, existem inúmeras dificuldades na determinação dessas exigências, devido às diferenças na eficiência de utilização de energia para os diversos processos fisiológicos, como mantença, crescimento e engorda. Além disso, outros fatores como o clima e a concentração de energia bruta no alimento influenciam a eficiência de utilização de energia para a mantença e o ganho de peso. Brody (1945) e, Blaxter e Boyne (1978), apud GEAY (1984), trabalhando com animais em crescimento e engorda, observaram uma relação curvilínea entre a energia bruta ingerida e a retenção de energia metabolizável pelos animais. Incrementos constantes na ingestão diária resultaram em incrementos progressivamente menores na retenção de energia. Segundo o autor, a explicação seria um decréscimo na metabolizabilidade da dieta com o aumento no nível de ingestão de energia devido a uma taxa de passagem mais rápida, a qual reduz a digestão de amido e de carboidratos da parede celular diminuindo a digestibilidade e aumentando as perdas nas fezes. $\mathrm{Na}$ verdade esta é só parte da explicação, pois a depressão da digestibilidade não explica totalmente a curvilinearidade desta relação. Provavelmente há uma menor eficiência metabólica em função do aumento do peso de certos componentes corporais como o fígado.

Segundo COELHO da SILVA e LEÃO (1979), as exigências energéticas dos animais são as mais difíceis de serem determinadas, pois a eficiência de utilização da energia para os vários processos fisiológicos - 
mantença, crescimento, engorda e lactação - é variável, além do fato de existirem muitas outras interferências, como o clima, os exercícios do animal e a concentração de energia metabolizável do alimento.

Um constante incremento na ingestão de energia diária resulta em progressiva diminuição da retenção de energia diária. Segundo TYRREL et al. (1974), o decréscimo pode ser devido a uma aceleração na taxa de passagem. Esta aceleração reduz a digestão do amido e da parede celular dos carboidratos (ØRSKOV et al., 1969), e assim diminui a digestibilidade (VERMOREL e BICKEL, 1980) e aumenta as perdas nas fezes (TYRREL et al., 1974), reduz a produção de $\mathrm{CH}_{4}$ ruminal (BOUVIER e VERMOREL, 1975; THORBEK, 1980) e perdas urinárias (VERMOREL e BICKEL, 1980). Como já foi citado anteriormente, também há uma provável redução na eficiência metabólica em função do aumento de peso de componentes corporais, como o fígado.

LIMA (1986) concluiu que animais da raça Nelore digerem energia com maior eficiência que Holandês e búfalos, não diferindo dos mestiços europeu-zebu. Entretanto, isto é variável, pois zebuínos (algumas vezes) são mais eficientes em dietas com alta proporção de forragem de baixa qualidade, mas são piores em dietas com alta proporção de concentrados.

Dados não publicados obtidos por Robelin e Geay, apud GEAY (1984), mostram uma relação entre energia retida e ingestão de energia, embora essa relação não seja estatisticamente curvilínea. Os autores utilizaram machos inteiros em crescimento das raças Friesian e Charolesa alimentados com dietas com alto teor de concentrado e três níveis de energia (ad libitum, $75 \%$ e $50 \%$ do ad libitum). A comparação foi feita a uma mesma idade fisiológica com base na porcentagem do peso maduro (30 e $55 \%$ ), sendo a retenção de energia e proteína medida pela técnica do abate comparativo. Os animais das duas raças recebendo alimentação ad libitum retiveram quantidades semelhantes de energia à uma mesma ingestão de energia bruta. No entanto, os Charoleses retiveram $42 \%$ mais energia como proteína em relação aos Friesian e apresentaram maior ganho de peso 
indicando que a utilização da energia metabolizável seria diferente entre as duas raças.

LOFGREEN e GARRET (1968) separam os requerimentos energéticos do animal em energia líquida para mantença e energia líquida para ganho. A primeira pode variar com a raça, o sexo e o nível nutricional (KOONG et al., 1985).

De acordo com FERREL e JENKINS (1998) as variações na mantença e eficiência do ganho, freqüentemente, estão associadas com o peso e a atividade metabólica de órgãos viscerais, como intestino e fígado. Os tecidos viscerais consomem cerca de $50 \%$ da energia destinada à mantença, enquanto os músculos, embora apresentem maior massa no corpo vazio dos animais, consomem apenas $23 \%$ do total da energia para mantença (CATTON e DHUYVETTER, 1997). Isso ocorre porque certos tecidos associados com a digestão, como o trato gastrintestinal e o fígado, têm maior "turnover" protéico do que o músculo esquelético (OWENS et al., 1993). Segundo HOOG (1991), os tecidos do trato gastrintestinal podem contribuir com mais de $40 \%$, e o fígado com $18 \%$ da síntese protéica.

Segundo GARRET (1980), o conhecimento da relação entre a deposição de energia e o ganho de peso é necessário para utilizar o sistema de energia líquida na formulação de dietas, para taxas de ganho específicas, ou para determinar a taxa de ganho do animal recebendo quantidade conhecida de um alimento específico ou mistura de alimentos. De qualquer forma, o conteúdo de energia no ganho é influenciado pelo sexo, pela classe, pela raça, e, em menor escala, pelo uso de hormônios adjuvantes.

A eficiência de utilização de EM para produção é influenciada, principalmente, pelas características da dieta: o valor comparativo de volumoso e concentrado, o teor de fibra, o tempo de ingestão e ruminação e as relações de ácidos graxos voláteis no rúmen (VAN SOEST, 1994).

Os trabalhos sobre exigências nutricionais de raças zebuínas e seus cruzamentos são escassos na literatura. O modelo de computador (Cornell Net Carbohydrate and Protein System - CNPCS) desenvolvido por FOX et al. (1992), possibilita estimar as exigências nutricionais para diferentes 
grupos genéticos utilizando dados de FRISCH e VERCOE (1977) e BOIN (1995) para a estimativa das exigências de energia para a mantença e, de KEARL (1982) e LANA et al. (1992) para estimar a concentração de energia líquida do ganho de peso em raças zebuínas. No entanto, esses dados são limitados quando comparados com resultados utilizados para a estimativa das exigências nutricionais com taurinos.

FRISCH e VERCOE (1977), PIRES et al. (1993b) e BOIN (1995) verificaram que animais da raça Nelore apresentavam exigência de energia para a mantença aproximadamente $10 \%$ inferior (69 kcal/kg PV0,75) em relação aos bovinos europeus. No entanto, a utilização desse valor para animais cruzados é controvertida, pois os mesmos apresentam exigências nutricionais para a mantença superior ao Nelore (LANA et al., 1992; PIRES et al., 1993b).

De acordo com GARRET et al. (1959), a composição do ganho de peso determina as diferenças na exigência de energia para ganho em animais de raças diferentes. Raças de maturação tardia apresentam menor teor de gordura no ganho de peso em relação às de maturação precoce para um mesmo peso vivo. BARBER et al. (1981) observaram que a porcentagem de energia da dieta retida no ganho de peso vazio foi maior em novilhos Angus comparados ao Charolês, indicando melhor eficiência energética dos animais Angus, proporcionada pela maior deposição de gordura no corpo vazio, a qual resultou em maior exigência de energia para ganho em relação aos Charolês.

No Brasil, TEIXEIRA et al. (1987), LANA et al. (1992) e PIRES et al. (1993b) estudando os requerimentos de energia de animais da raça Nelore e suas cruzas com Holandês, Limousin, Marchigiana e Chianina observaram que o Nelore apresentou maior exigência de energia líquida para ganho de peso do que os animais dos demais grupos. FONTES (1995) analisando diversos trabalhos de literatura sobre composição corporal e exigências nutricionais de raças zebuínas de corte e cruzados europeu-zebu, inteiros e castrados, verificou que os animais Nelore apresentaram maiores conteúdos corporais e exigências de energia para ganho de peso que os mestiços, o 
mesmo ocorrendo com os animais castrados em relação aos inteiros. BOIN (1995) verificou um aumento das exigências de energia líquida para ganho de peso com o aumento do peso vivo e da taxa de ganho de peso para animais Nelore inteiros e castrados. Os animais inteiros apresentaram maior concentração de proteína e menor concentração de energia por quilo de ganho de peso do corpo vazio em relação aos castrados.

Para a determinação das exigências dietéticas deve-se considerar a eficiência de utilização de energia metabolizável nos animais. E apesar de já terem sido publicados vários trabalhos sobre exigências nutricionais em condições brasileiras, ainda existe carência de fatores para a conversão das exigências líquidas em dietéticas (FERREIRA et al., 1998b).

\subsection{Exigências de proteína}

Uma das principais metas da pesquisa para a produção de carne em bovinos em crescimento é buscar o aumento da deposição de proteína muscular e da eficiência de utilização de aminoácidos da dieta, ao longo do aumento da eficiência de utilização da energia. Um mínimo de deposição de gordura associado com a síntese de proteína é inevitável, e necessário para assegurar um bom sabor à carne (GEAY, 1984). A eficiência de utilização de uma dieta para a deposição de tecidos depende do conhecimento das exigências de nutrientes pelos animais, e entre eles, o requerimento de proteína bruta (PB) é importante.

Segundo o NRC (1996), as exigências de proteína metabolizável consistem na soma da proteína não-degradada no rúmen digestível (PNDRd) e a proteína microbiana verdadeira digestível (PMIVd); os requerimentos de PB são obtidos pelo somatório da proteína degradada no rúmen $(P D R)$ e a proteína não degradada no rúmen (PNDR). Para este sistema, a PDR consiste em $130 \mathrm{~g}$ de $\mathrm{PB} / \mathrm{kg}$ de nutrientes digestíveis totais (NDT) consumidos. Conhecendo-se a síntese de proteína microbiana e assumindo-se que $80 \%$ desta é verdadeira e possui digestibilidade de $80 \%$, chega-se a PMIVd. A PNDRd é obtida pela PNDR com correção de $80 \%$ de digestibilidade. 
A eficiência de utilização de energia metabolizável para síntese de proteína e gordura em ruminantes ainda não foi definida com segurança (SIGNORETTI et al., 1999). GARRET (1980) relatou que a eficiência de utilização da energia metabolizável na síntese de proteína variou de 10 a $42 \%$ e na síntese de gordura, de 60 a $80 \%$.

Segundo GEAY (1984), os requerimentos líquidos de proteína tendem a ser menos importantes em relação aos requerimentos energéticos para novilhos em crescimento com maturação precoce como os das raças Angus e Hereford. Isso ocorre devido a menor retenção de sua energia como proteína (12 a 15\%) e conter somente $12 \%$ de proteína no ganho de peso vivo. Esse tipo de animal preenche suas exigências protéicas utilizando somente os aminoácidos provenientes da fermentação microbiana (GEAY, 1984).

ROHR e DAENICKE (1984) encontraram requerimentos protéicos mais elevados trabalhando com tourinhos em crescimento de raças de maturidade tardia (Simental, Limousin e Charolês), os quais retiveram ao redor de $38 \%$ de energia como proteína. Esse tipo de animal não consegue preencher suas exigências protéicas somente com aminoácidos supridos pelas bactérias do rúmen, independente do seu peso vivo ou do ganho de peso diário.

As exigências protéicas, para ganho de peso, variam com a raça, o sexo e a taxa de ganho de peso, sendo maiores nos animais inteiros, em relação aos animais castrados e, para mesmo sexo, são maiores para animais de maturidade tardia, em relação aos de maturidade precoce (GEAY, 1984). A equação desenvolvida por esse autor mostra que há aumento na deposição de proteína com o aumento do ganho diário de peso, independente do peso vivo e, que essa deposição diminui com o aumento do peso vivo, sendo mais acentuada com altas taxas de ganho.

De maneira geral, a maioria dos trabalhos mostraram queda nos requerimentos líquidos de proteína, à medida que o peso corporal se eleva (LANA et al., 1992; PIRES et al., 1993a; FONTES, 1995; e PAULINO, 1996). 
A exigência de proteína dos ruminantes é atendida pelos aminoácidos absorvidos no intestino delgado, denominada exigência de proteína metabolizável. A proteína que chega ao intestino delgado consiste de fração microbiana, da fração dietética não-degradada no rúmen e da proteína endógena (VALADARES FILHO, 1997).

Para que a eficiência de síntese de proteína pelos microrganismos ruminais seja máxima, a degradabilidade da proteína dietética deve atender exatamente às necessidades microbianas, desde que não haja limitação da fonte energética entre outros fatores. E para que a eficiência de utilização de proteína nos tecidos seja máxima, a soma da proteína microbiana e da proteína dietética não-degradada no rúmen deve atender às exigências dos tecidos, em termos quantitativos e qualitativos (WALDO e GLEN, 1981).

VAN KESSEL e RUSSEL (1996) realizaram cultivos contínuos de bactérias ruminais e encontraram efeito positivo do nitrogênio sobre a eficiência de síntese microbiana somente quando havia quantidade de energia em excesso. E quando havia limitação energética, porém com altos níveis de amônia, a suplementação com peptídeos e aminoácidos não modificaram os ritmos de crescimento da população microbiana cultivada.

BARBER et al. (1981) trabalhando com novilhos Angus e Charolês abatidos em um mesmo estado de maturidade fisiológica observaram que animais Angus apresentaram menor porcentagem de proteína no corpo vazio. Observação semelhante foi feita por ROHR e DAENICKE (1984) trabalhando com animais Friesian e Charolês indicando que as raças de maturidade precoce apresentam mudanças maiores na deposição de proteína em relação às raças de maturidade tardia. Esses autores observaram que um aumento de ingestão de energia de 3 para $13 \%$ decresceu a deposição de proteína no ganho de peso do corpo vazio para os tourinhos Holandeses. No entanto, não foi observada nenhuma mudança na composição química do ganho com os animais Charolês.

ANDERSON et al. (1988a) avaliaram os efeitos de níveis crescentes de proteína (10, 12 e 14\%) sobre a taxa e a composição do ganho de peso de tourinhos cruzados Angus $X$ Hereford utilizando dietas isoenergéticas. $O$ 
ganho de peso vivo foi maior para os níveis mais altos de proteína. Embora não havendo diferença na porcentagem de proteína da carcaça, esta apresentou maior deposição desse componente nos animais que receberam a dieta com $14 \%$ de proteína bruta. Os mesmos autores, trabalhando com tourinhos da raça Simental recebendo a mesma dieta do ensaio anterior encontraram resultados semelhantes indicando que o nível mais baixo de proteína $(10 \%)$ na dieta não seria adequado para ser usado em animais jovens quando o objetivo é obter altas taxas de ganho de peso. ANDERSON et al. (1988b) trabalhando com animais inteiros e castrados da raça Simental, abatidos na mesma faixa de peso vivo, observaram que os primeiros apresentaram maior taxa de deposição de proteína na carcaça, embora a taxa de deposição de gordura fosse semelhante entre os dois grupos. Segundo os autores, a produção de carcaças mais magras pelos animais inteiros ocorre, principalmente, devido ao maior acúmulo de tecido muscular com uma menor deposição de gordura para esse tipo de animal.

No Brasil, diversos trabalhos foram realizados visando estimar as exigências de proteína para ganho de peso, principalmente com raças zebuínas (TEIXEIRA et al., 1987; GONÇALVES et al., 1991b; LANA et al., 1992; PIRES et al., 1993a; BOIN, 1995). Nos trabalhos em que foram comparados animais da raça Nelore com mestiços europeu $\mathrm{X}$ zebu, os primeiros apresentaram maior exigência de proteína para ganho de peso.

De acordo com VÉRAS et al. (2001), compilando dados de animais de dois experimentos, um com Nelore não-castrado e outro com animais F1 Nelore x Simental, não-castrados, observaram que os requisitos de proteína metabolizável (PM) para mantença aumentaram com a elevação do peso vivo. Já os requerimentos de proteína metabolizável para ganho apresentaram o mesmo comportamento verificado para os respectivos requisitos líquidos e, foram de 309, 296, 285, 276 e $268 \mathrm{~g} / \mathrm{kg}$ de ganho do peso corporal vazio, respectivamente para animais com 300, 350, 400, 450 e $500 \mathrm{~kg}$. De um modo geral, os valores encontrados foram próximos aos preconizados pelo NRC (1996) para bovinos com 300, 350, 400 e $450 \mathrm{~kg}$, que são de 303, 298, 272, e 246 g/dia, respectivamente. 


\subsection{Consumo e digestibilidade}

A ingestão voluntária é determinante para o balanceamento de rações e para o estabelecimento de estratégias de alimentação que permitam maior desempenho de bovinos (VAN SOEST, 1994; NATIONAL RESEARCH COUNCIL - NRC, 1996).

A suplementação com energia ou proteína, geralmente leva a uma queda no consumo de forragens, causando o chamado efeito de substituição (LANNA et al., 1998b). Pesquisas comparativas entre Bos taurus taurus e Bos taurus indicus sugerem que há diferenças entre os dois grupos quanto à ingestão alimentar e eficiência de utilização de rações com alta ou baixa densidade de energia (OLIVEIRA et al., 1994).

Por outro lado, segundo DOVE (1996), o consumo pode ser limitado pela deficiência em proteína da ração. Em rações desbalanceadas, com baixa disponibilidade de compostos nitrogenados $(\mathrm{N})$ e ricas em FDN, o suprimento de proteína degradada no rúmen (PDR) é limitante para o crescimento microbiano, a digestão da parede celular fica comprometida e a ingestão de alimentos é reduzida.

O consumo e a digestibilidade de nutrientes podem estar correlacionados entre si, dependendo da qualidade da ração. Para rações de alta digestibilidade (acima de 66\%), ricas em concentrados (acima de 75\%) e com baixo teor de FDN (abaixo de 25\%), o consumo será menor quanto mais digestivo for o alimento e, em rações de baixa qualidade (acima de $75 \%$ de FDN), o consumo será maior quanto melhor for a digestibilidade do alimento (VAN SOEST, 1994; MERTENS, 1994).

Em zebuínos, o efeito de substituição parece ser mais intenso do que em taurinos, à medida que se aumenta a porcentagem de concentrados na dieta. Dados de desempenho de animais Nelore confinados foram incompatíveis com as estimativas de NDT, com silagem de milho (BOIN e MOURA, 1977), e com bagaço de cana hidrolisado a pressão e vapor (MEDEIROS, 1992).

Revisando a literatura, LANNA et al. (1998b) encontraram redução no desempenho esperado de zebuínos quando o nível de concentrado na dieta 
foi superior a $50 \%$ da matéria seca total. Segundo os mesmos autores, os trabalhos sobre digestibilidade com zebuínos publicados no Brasil, indicam que por volta de $67 \%$ de NDT uma maior inclusão de concentrados na dieta parece não aumentar com consistência a digestibilidade ou o valor energético da dieta (a maior parte dos trabalhos indicados na revisão utilizava o milho como fonte de energia).

Em rações com 40 e $60 \%$ de concentrados, foi verificado maior consumo, por unidade de peso vivo, em taurinos do que em zebuínos, e consumo intermediário em mestiços, de acordo com LEDGER et al. (1970). VALADARES FILHO et al. (1985) verificaram maior digestibilidade da matéria seca em zebuínos, em comparação a novilhos holandeses e mestiços holandês-zebu, quando a ração continha menor proporção de concentrado.

Geralmente, depressões na digestibilidade são resultantes da competição entre digestão e passagem. Um aumento significativo no consumo pode levar a uma maior taxa de passagem, reduzindo a digestibilidade (FAHEY JR. E BERGER, 1988; VAN SOEST, 1994). Desta forma, respostas positivas no consumo estão relacionadas a quedas na digestibilidade da dieta (FAHEY JR. E BERGER, 1988).

Resultados contrários foram encontrados por GOMES (1982), que comparando o consumo alimentar de animais zebuínos, holandeses e mestiços alimentados com rações que continham 40 e $60 \%$ de concentrado, não verificou diferença entre grupos ou influência do nível de concentrado da ração sobre o consumo de matéria seca.

Testando níveis de concentrados de 20 e $60 \%$ na dieta de zebuínos, ANDRADE (1992) e GONÇALVES et al. (1991a) verificaram diferença para os consumos de matéria seca e matéria orgânica. Também foram verificadas diferenças para o consumo de proteína bruta e de energia bruta (GONÇALVES et al., 1991a).

HORROCKS e PHILIPS (1961) e HUNTER e SIEBERT (1985) concluíram que não existem diferenças na ingestão de matéria seca entre zebuínos e taurinos. 
CARDOSO et al. (2000), não verificaram alterações nas digestibilidades ruminais e intestinais da matéria seca (MS) e matéria orgânica (MO), de animais F1 Limousin X Nelore, alimentados com 25; 37,5; 50; 62,5; e 75\% de concentrado na dieta. A digestibilidade aparente total da MS, MO, proteína bruta, extrato etéreo e carboidratos totais apresentaram comportamento linear positivo, em função dos níveis crescentes de concentrado nas rações experimentais.

A digestão da celulose, presente no volumoso, é a principal função ruminal. Os microrganismos celulolíticos tendem a diminuir na presença de substratos competitivos como o amido. Algumas espécies ruminais são facultativas quanto ao consumo de celulose e amido. Por isso é difícil associar o número de microrganismos celulolíticos com a digestão da celulose. $\mathrm{E}$, os substratos facilmente degradáveis são mais competitivos (VAN SOEST, 1994). Os organismos celulolíticos, hemicelulolíticos e pectinolíticos são inibidos por pH baixo (Grant and Mertens, 1992; apud VAN SOEST, 1994), que aparece normalmente em dietas de alta proporção de concentrados.

A quantidade e composição da dieta são variáveis que afetam a taxa de digestão, taxa de passagem e, portanto, o "turnover" do conteúdo ruminal. A ingestão pelo animal depende da composição e disponibilidade do alimento. A composição da dieta geralmente determina a distribuição da população microbiana que digere os nutrientes dos alimentos no rúmen. Assim, dietas com alta proporção de proteínas favorecem organismos proteolíticos, e dietas com alta proporção de amido (que são pobres em fibras), estão associadas com uma grande população de microrganismos amilolíticos (VAN SOEST, 1994).

Segundo PATERSON et al. (1994), a digestibilidade da forragem determina o desaparecimento de nutrientes no rúmen. Em rações com taxas de digestão dos nutrientes acima de $66 \%$ de digestibilidade aparente total, há menor resíduo ruminal e rápida renovação de material no rúmen; forragens de melhor qualidade atingem rapidamente os pontos finais de digestão, minimizando a limitação de consumo pelo "enchimento". 


\subsection{Composição corporal e ganho de peso}

A composição corporal de bovinos vem sendo estudada por vários autores. Alguns destes trabalhos foram realizados por LEME et al. (1994) e ALLEONI et al. (1997) com animais castrados da raça Nelore; BOIN (1995) que fez um resumo dos trabalhos sobre Nelore; LANNA et al. (1995) com touros zebu; LANNA et al. (1997b) com vários grupos genéticos; HENRIQUE et al. (1999) com animais Santa Gertrudis; ALLEONI (em andamento) com animais Canchim; BERNDT et al. (2000) com tourinhos Santa Gertrudis; e VÉRAS et al. (2001) com animais Nelore e F1 Simental X Nelore não-castrados.

A determinação da composição corporal dos animais é fundamental para a avaliação do valor nutricional dos alimentos e em estudos do crescimento animal. O crescimento normal de um animal deve ser entendido como um conjunto de modificações físicas, químicas e funcionais de seu organismo (BOIN et al., 1994).

Os principais componentes químicos do corpo de um bovino são água, gordura, proteína e minerais. A maturidade do animal é refletida por aumento na proporção de gordura, enquanto que a proporção de água e de proteína do corpo se mantém relativamente constante. Os animais mais jovens são mais ricos em água e mais pobres em gordura, sendo que as concentrações de proteína, cinzas e água decrescem com a idade e com a engorda (FERREIRA et al., 1998a).

Em relação aos tecidos, os que compõem a carcaça de animais domésticos são principalmente ósseo, muscular e adiposo. $\mathrm{O}$ desenvolvimento de cada um destes tecidos não é sincronizado e isométrico.

A velocidade de crescimento dos diferentes tecidos do corpo é variável em função das fases de crescimento e maturidade fisiológica do animal. Inicialmente o tecido ósseo tem maior taxa de crescimento em relação ao músculo e à gordura, nesta ordem. A proporção de ossos na carcaça diminui lentamente à medida que o peso do animal aumenta, apresentando menor variação percentual. Os músculos representam alta 
porcentagem do peso total ao nascimento, aumentando ligeiramente, passando a decrescer à medida que se inicia a fase de deposição de gordura (LAWRENCE e FOWLER, 1997). Segundo LANNA (1997a), a taxa de maturação talvez seja o parâmetro mais importante nas curvas de crescimento, podendo ser alterada por modificações de manejo e genótipo.

A proporção e a velocidade com que os tecidos se acumulam no corpo influenciam o ganho de peso vivo, a eficiência alimentar e a composição do corpo (SHAHIN et al., 1993) e, consequentemente, as exigências nutricionais. Diferenças na musculatura, composição da gordura ou produção de leite podem mudar a proporção de tecidos metabolicamente ativos a alterar a relação entre requerimentos de mantença e ganho de peso (KOONG et al. 1985; TAYLOR et al., 1986.)

As mudanças nas proporções dos tecidos e em sua composição química são influenciadas por vários fatores, dentre os quais se destacam peso, idade, raça, nível de consumo de energia e o sexo (FERREIRA et al., 1998a). E segundo GARRET (1980), a raça teria uma influência mais acentuada sobre a composição corporal, a um mesmo peso vivo, do que o nível nutricional. Dados obtidos por Millward et al. (1976) e Arnall (1977), apud GARRET (1980), indicam que a quantidade de energia metabolizável para depositar proteína é maior do que a requerida para a deposição de gordura, e que a taxa de "turnover" da proteína dos tecidos é maior em animais jovens com rápido crescimento. Segundo o autor, a degradação e a ressíntese de proteína dos tecidos explicaria o acréscimo nas exigências energéticas de mantença, para um mesmo peso vivo, em raças bovinas que atingem a maturidade com pesos mais elevados, bem como animais inteiros e castrados.

Assim, a composição corporal é influenciada diretamente pela raça do animal. Dentro de espécies, a quantidade de gordura e proteína, para um mesmo peso vivo, varia entre raças, dependendo do tempo que as mesmas levam para atingir o tamanho maduro. Raças de maturação precoce têm mais gordura e menos proteína em relação às raças de maturação tardia (REID et al., 1980). ROBELIN e GEAY (1984) encontraram ganhos de 135, 
190, 190, 193, 108 e 102 gramas de tecido adiposo por quilo de ganho de peso, com animais das raças Holandês, Shorthorn, Hereford, Angus, Charolês e Limousin, respectivamente, confirmando os dados obtidos por REID et al. (1980).

O nível do consumo de energia pode modificar o uso da energia para síntese de proteína ou lipídios, ou em termos de tecidos, o desenvolvimento de músculo e tecido adiposo. JONES et al. (1985) observaram que animais alimentados com dietas à base de concentrado, apresentaram maiores teores de gordura na carcaça que aqueles cujas dietas eram à base de volumoso. A extensão em que a composição da carcaça e, ou, do corpo vazio, são modificados pelo consumo de energia é, também, influenciada pelo tipo de bovino (tamanho, maturidade, idade e sexo), sendo que mudanças mais pronunciadas na composição têm sido verificadas em bovinos de maturidade tardia, que possuem maior tendência a depositar proteína (FERREIRA et al., 1998a). Em animais de maturidade tardia, a redução no consumo de energia tem efeito mais depressivo na retenção de proteína que na gordura (GEAY, 1984).

RATTRAY e JOYCE (1976), indicam que os ganhos de peso associados com altas deposições de gordura foram mais eficientes, energeticamente, mas menos eficientes em relação à conversão de alimentos, em peso vivo, quando comparados a ganhos com pequena deposição de gordura. Isto ocorre porque os tecidos adiposos, onde ocorre grande parte do aumento de peso vivo, contêm teores mais elevados de matéria seca (LANA et al., 1992) que os músculos $(75-80 \%$ e $25-35 \%$, respectivamente).

O ganho de peso vivo entre raças ou sexos diferentes, a um mesmo peso vivo, depende fundamentalmente do nível de ingestão de energia. ROHR e DAENICKE (1984) citaram que com o aumento da ingestão de energia, o ganho de peso é maior em animais com menor peso corporal. Os resultados mostram também que animais de maturação tardia apresentam maior ganho de peso em relação aos de maturação precoce, e que machos inteiros ganham mais peso em relação aos castrados. No entanto, a 
ingestão de energia tem influência sobre o ganho de peso somente quando a dieta está balanceada em outros nutrientes, principalmente a proteína. Segundo os mesmos autores, existe um nível ótimo de concentração protéica, a partir do qual o ganho de peso vivo se estabiliza, independente do aumento do teor de proteína da dieta, e que esses níveis são mais elevados em animais mais leves.

Vários autores (FERREL e JENKINS, 1998; BYERS e ROMPALA, 1980; OWENS et al., 1995), relataram que as taxas de acréscimo de proteína e de energia são maximizadas a uma determinada taxa de ganho de peso corporal vazio, a partir da qual se mantém constante. Este comportamento foi verificado por FERREIRA et al. (1998b) e por VÉRAS et al. (2001), com animais F1 Simental x Nelore e Nelore, respectivamente, alimentados com dietas com níveis crescentes de concentrado.

Segundo BARBER et al. (1981), a composição corporal afeta diretamente a eficiência de utilização de alimentos para ganho de peso vivo e para produção de carne comestível. Sendo assim, o conhecimento das exigências de energia e proteína para a mantença e para o ganho de peso vivo de bovinos é de grande importância para o balanceamento de rações de custo mínimo para os diferentes níveis de desempenho animal.

As diferenças nas exigências de energia e proteína para ganho são atribuídas às diferenças na composição do ganho de peso (GARRET et al., 1959; GEAY, 1984). De acordo com LANA et al. (1992), as diferenças na composição do ganho de peso são responsáveis pela maior exigência de energia de animais em estádios mais avançados de maturidade fisiológica, pelas maiores exigências de animais precoces, em relação aos tardios a um mesmo peso vivo, e pela maior exigência das fêmeas em relação aos machos inteiros.

Animais tardios são considerados ideais em sistemas de nível nutricional elevado, porque estes animais podem ser abatidos com pesos maiores, alcançando o máximo desenvolvimento muscular, sem, contudo, depositar gordura em excesso. Já animais precoces apresentam maiores acúmulos de gordura e menores de proteína, mas o abate mais cedo destes 
animais pode oferecer um produto de melhor qualidade no mercado (BERG e BUTTERFIELD, 1976).

Segundo WEBSTER (1989), novilhos desmamados recebendo alimentos de baixa qualidade e ganhando $250 \mathrm{~g} / \mathrm{dia}$ retiveram apenas $3 \%$ da energia destes alimentos; $46 \%$ foram perdidas nas fezes e $41 \%$ como calor. Entretanto, um tourinho em confinamento, crescendo rapidamente e recebendo uma dieta altamente digestível retém $37 \%$ da energia metabolizável presente nos alimentos, dissipando 55\% como calor.

SIGNORETTI et al. (1999) comparando o desempenho de tourinhos recebendo diferentes níveis de inclusão de volumoso, observaram que a eficiência de utilização da energia metabolizável para ganho de peso foi maior para dietas com menor proporção de volumoso, isto é, maior concentração de energia bruta na dieta, obtendo valores de eficiência da ordem de 40\%. FERREIRA et al. (1998b) trabalhando com tourinhos cruzados Simental X Nelore obtiveram valores médios de 27 a $42 \%$ de eficiência para rações com diferentes proporções de concentrado. 


\section{OBJETIVOS}

O objetivo deste trabalho foi o de aumentar o conhecimento sobre a composição corporal de animais Nelore e Brangus. A raça Nelore compõe grande parte do rebanho brasileiro e os animais Brangus se apresentam como um dos mais importantes cruzamentos (5/8Angus $X$ 3/8Nelore) utilizados pela pecuária nacional, mas existem poucos dados sobre as exigências líquidas de energia e proteína para a raça nas nossas condições.

Assim, os objetivos deste trabalho foram estimar as exigências de proteína e energia para o ganho de peso de animais das raças Brangus e Nelore através da técnica de abate comparativo. Para isso foram estabelecidas as relações entre os componentes químicos (água, proteína, extrato etéreo e matéria mineral) a partir do corte da 9-10-11a costelas; estimadas as taxas de deposição dos tecidos, e avaliadas as diferenças de ingestão e digestibilidade de dietas com diferentes proporções de concentrado para esses animais. 


\section{MATERIAL E MÉTODOS}

\subsection{Local}

O experimento foi realizado na Faculdade de Zootecnia e Engenharia de Alimentos da Universidade de São Paulo (FZEA/USP), em Pirassununga, SP.

\subsection{Confinamento}

\subsubsection{Animais e alimentação}

Foram utilizados cinqüenta e seis bovinos machos inteiros (vinte e oito animais de cada raça) com idade inicial de oito meses e pesos médios iniciais de $210 \mathrm{~kg}$ e $214 \mathrm{~kg}$, respectivamente para as raças Brangus (5/8Angus X 3/8Nelore) e Nelore. Os animais estavam sendo mantidos em pastagem antes do início do confinamento e apresentavam escore corporal ao redor de 4, numa escala de 1 a 9 (onde 1 são animais muito magros e 9 muito gordos).

Quatro animais de cada raça, escolhidos por sorteio, foram abatidos no início do período de alimentação para estimar o peso vazio e a composição corporal inicial do lote. Os demais animais, vinte e quatro Nelore e vinte e quatro Brangus, foram confinados em baias coletivas (doze animais de cada raça por baia, com alimentação individualmente controlada através de portões eletrônicos do tipo Calan). As rações experimentais foram compostas de 20,40, 60 e $80 \%$ de concentrado na matéria seca e o volumoso utilizado foi a silagem de milho, que apresentava grande quantidade de grãos e tamanho de partícula de aproximadamente $2 \mathrm{~cm}$.

Os animais foram confinados por 145 dias, após um período de adaptação de 28 dias às dietas em que o concentrado foi aumentado semanalmente até atingir os níveis de 60 e $80 \%$. Os animais foram 
selecionados por sorteio para cada uma das dietas. Diariamente foram medidas as quantidades oferecidas e as sobras retiradas três vezes por semana. Os animais foram pesados em intervalos de 28 dias após jejum completo de aproximadamente 18 horas. No período final do experimento (últimos 42 dias) as pesagens foram realizadas a cada 14 dias, para acompanhamento mais intenso do desempenho dos animais.

\subsubsection{Rações experimentais}

As dietas foram formuladas no programa RLM e checadas de acordo com o CNCPS (Cornell Net Carbohydrate and Protein System - CNPCS) desenvolvido por FOX et al. (1992), e oferecidas à vontade. Os ingredientes das rações experimentais estão descritos na Tabela 1.

Tabela 1. Ingredientes das rações experimentais (valores expressos em porcentagem da matéria seca)

\begin{tabular}{lcccc}
\hline \multirow{1}{*}{ Ingredientes } & \multicolumn{3}{c}{ Porcentagem de concentrado na dieta (em base seca) } \\
\cline { 2 - 5 } & $\mathbf{2 0 \%}$ (Ração A) & $\mathbf{4 0 \%}$ (Ração B) & $\mathbf{6 0 \%}$ (Ração C) & $\mathbf{8 0 \%}$ (Ração D) \\
\hline Silagem de milho & 80,00 & 60,00 & 40,00 & 20,00 \\
Farelo de soja (49\%) & 10,050 & 8,699 & 7,979 & 7,716 \\
Milho grão seco & 6,952 & 27,910 & 48,101 & 67,977 \\
Uréia & 0,099 & 0,520 & 0,820 & 1,000 \\
Sulfato de amônia & 0,400 & 0,400 & 0,400 & 0,607 \\
Cloreto de potássio & 0,900 & 0,900 & 0,900 & 0,900 \\
Sal mineral & 0,600 & 0,600 & 0,600 & 0,600 \\
Calcáreo & 1,000 & 1,000 & 1,200 & 1,200 \\
Rumensina & 0,027 & 0,027 & 0,027 & 0,027 \\
\hline
\end{tabular}

O grão de milho foi moído em peneira grossa, no tamanho de quirera (8 a 10 pedaços por grão).

\subsubsection{Análises bromatológicas das rações}

Amostras semanais dos alimentos oferecidos foram colhidas para composição de amostras compostas, a cada quatro semanas para análise bromatológica. As análises foram feitas de acordo com a metodologia de Weende (SILVA, 1998). Os resultados médios das análises bromatológicas dos alimentos estão descritos na Tabela 2. 
Tabela 2. Análises bromatológicas das rações experimentais (valores expressos em porcentagem da matéria seca)

\begin{tabular}{lccccccc}
\hline \multicolumn{1}{c}{ Amostra } & $M S$ & $P B$ & $F B$ & $E E$ & $M M$ & $F D N$ & $F D A$ \\
\hline Milho em grão & 89,34 & 11,51 & 3,21 & 5,46 & 2,27 & - & - \\
Farelo de soja & 87,81 & 49,22 & 6,34 & 1,67 & 7,08 & - & - \\
Silagem de milho & 30,86 & 7,83 & 24.89 & 2,40 & 4,37 & 59.12 & 34.36 \\
Ração A & 89,59 & 34.95 & 3,96 & 2,50 & 12,41 & - & - \\
Ração B & 89,04 & 23,15 & 3,55 & 3,44 & 6,23 & - & - \\
Ração C & 89,01 & 19,15 & 3,73 & 3,56 & 4,76 & - & - \\
Ração D & 88,60 & 17,74 & 3,38 & 3,75 & 4,21 & - & - \\
\hline
\end{tabular}

\subsubsection{Análises de glicose no plasma sanguíneo}

Foi realizada uma colheita de amostras de sangue de todos os animais para a determinação do teor de glicose. Os valores normais de glicose sanguínea são de 40 a 80 mg/dl para bovinos adultos e de 80 a 120 mg/dl para bovinos jovens (DUKES, 1996).

O sangue foi colhido em tubos do tipo "vacutainer" com fluoreto de sódio que diminui a atividade de oxiredução. Logo após a colheita, o sangue foi centrifugado a $3000 \mathrm{rpm}$ durante 15 minutos. O soro foi pipetado e armazenado em freezer em tubos "ependorf". As análises foram realizadas através do uso de kits comerciais da marca Laborlab®.

\subsubsection{Análises de uréia no soro sanguíneo}

A análise de uréia indica o balanço protéico da dieta. Valores normais de nitrogênio uréico no sangue (NUS) de bovinos estão entre 10 e 30 mg/dl (DUKES, 1996). Foi realizada uma colheita de sangue de todos os animais para a determinação do teor de uréia.

O sangue foi colhido em tubos do tipo "vacutainer" sem reagentes. Logo após a colheita o sangue foi centrifugado a 3000 rpm durante 15 minutos. O soro foi pipetado e armazenado em freezer em tubos "ependorf".

A determinação do teor de uréia no soro foi obtida através do uso de kits comerciais da marca Laborlab ${ }^{\circledR}$. Os valores de uréia obtidos foram multiplicados por 0,466 , para se obter o nitrogênio no plasma (NUP) em mg/dl (LIMA, 2002). Para a obtenção do valor de nitrogênio originário da uréia sanguínea (NUS), em mg/dl, a partir do NUP, foi utilizada a equação de regressão de BRODERICK e CLAYTON (1997).

$$
\mathrm{NUP}=1,021 \mathrm{NUS}+0,399\left(R^{2}=0,918\right)
$$


As colheitas de sangue para determinação dos teores de glicose e uréia foram realizadas após o fornecimento de alimento para os animais, a fim de se obter amostras de sangue pós-ingestão das dietas.

\subsection{Abate e composição corporal}

O abate dos animais foi realizado no "Matadouro-Escola" da Prefeitura do Campus Administrativo da USP, Pirassununga/SP e em frigorífico comercial (Frigorífico Minerva, Barretos/SP), seguindo os mesmos padrões de abate.

Os oito animais abatidos no início do experimento (quatro Brangus e quatro Nelore) foram denominados "linha base" e foram utilizados para a composição corporal inicial.

\subsubsection{Estimativa do peso vazio (PCVz)}

A partir do peso da carcaça quente obtido pós-abate, foi estimado o PCVz, segundo equações de ALLEONI et al. (2001) para as raças Brangus e Nelore.

a) Brangus

$$
\begin{aligned}
P C V z & =12,47625+1,48221 \times P C Q \\
R^{2} & =0,986 \\
\text { Syx } & =12,569
\end{aligned}
$$

b) Nelore

$$
\begin{aligned}
P C V z & =15,58582+1,45488 \times P C Q \\
R^{2} & =0,976 \\
\text { Syx } & =16,261
\end{aligned}
$$

Onde:

PCVz: Peso vazio

PCQ: Peso da carcaça quente

$\mathrm{R}^{2}$ : Coeficiente de correlação

Syx: Desvio padrão da estimativa 


\subsubsection{Corte da 9-10-11 a costelas}

As meias carcaças foram colocadas em câmara de resfriamento, na temperatura aproximada de $2^{\circ} \mathrm{C}$ por 24 horas. Após o resfriamento, foi retirado o corte da 9-10-11 ${ }^{a}$ costelas da meia carcaça esquerda, de acordo com a metodologia proposta por HANKINS e HOWE (1946).

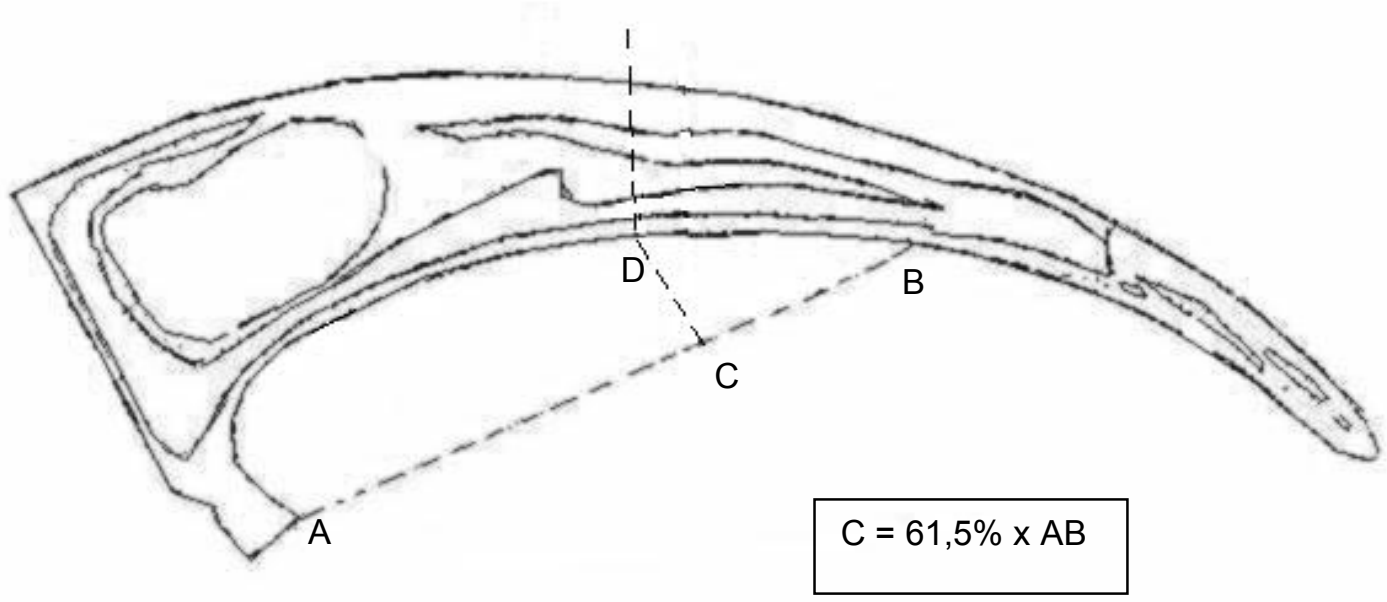

Figura 1. Vista da secção da $9-10-11^{a}$ costelas através de um corte perpendicular a coluna dorsal na altura da $12^{\mathrm{a}}$ costela.

O valor da reta "AB" foi obtido a partir da ponta do osso até o fim da costela. Em seguida foi calculado $61,5 \%$ da reta " $A B$ ", determinando-se o ponto "C". No ponto " $C$ " foi traçada uma reta perpendicular a "AB", obtendose o ponto " $D$ ". O corte foi realizado passando pelo ponto " $D$ " (de acordo com a linha tracejada), e a porção separada para a análise foi a que continha o músculo Longissimus thoracis (lado esquerdo figura).

Em seguida, as amostras foram congeladas e posteriormente cortadas com serra elétrica de fita e moídas em moedor de grande porte (Herman P - 33a - 3 - 789, 15 HP). As amostras foram moídas duas vezes em peneira com furos de $23 \mathrm{~mm}$, duas vezes em peneira com furos de $8 \mathrm{~mm}$ e duas vezes em peneira com furos de $5 \mathrm{~mm}$. Na última moagem foram colhidas amostras de 350 gramas do material homogeneizado, e divididas em quatro placas de Petri. Estas placas foram liofilizadas até atingirem peso constante, obtendo-se, assim, o teor de água do corte da costela. 
As amostras liofilizadas foram moídas em liquidificador com copo de aço inox adicionando-se gelo seco ( $\mathrm{CO} 2$ sólido). Estas amostras foram analisadas.

Foi determinado o teor de MS de cada amostra, em estufa a $105^{\circ} \mathrm{C}$ por 24 horas. A porcentagem de extrato etéreo do corte foi calculada através da perda de peso da amostra após 15 horas de extração em aparelho Soxlet.

\subsubsection{Estimativa da porcentagem de água e gordura no corpo vazio} $(\mathrm{CVz})$

A partir do teor de água do corte da $9-10-11^{a}$ costelas foram estimadas as porcentagens de água e gordura no corpo vazio, utilizando-se equações de ALLEONI et al. (2001), para a raça Brangus.

a) Brangus

\% água $C V z=0,1413+1,0255 \times \%$ água corte

$$
\left(R^{2}=0,946 ; \text { Syx }=0,734\right)
$$

$\%$ gordura $C V z=90,14538-1,21282 \times \%$ água corte

$$
\left(R^{2}=0,853 ; \text { Syx }=1,503\right)
$$

Onde: $C V z$ : corpo vazio

\%água corte: \% água no corte da $9-10-11^{\text {a }}$ costelas

$\mathrm{R}^{2}$ : Coeficiente de correlação

Syx: Desvio padrão da estimativa

Para a raça Nelore a porcentagem de água e gordura no corpo vazio foi estimada a partir da porcentagem de gordura do corte da 9-10-11 a costelas, utilizando-se equações de LANNA (1988).

b) Nelore

$$
\begin{aligned}
& \% \text { água Cvz }=24,1936+0,6574 \times \% \text { água corte } \\
& \qquad\left(R^{2}=0,93 ; \text { Syx }=0,8\right) \\
& \% \text { gordura Cvz }=8,9+0,0161 \times(\% \text { gordura corte })^{2} \\
& \left(R^{2}=0,95 ; \text { Syx }=0,8\right)
\end{aligned}
$$


Onde: $C V z$ : corpo vazio

$\%$ água corte: \% água no corte da $9-10-11^{a}$ costelas

$\%$ gordura corte: $\%$ de gordura no corte da $9-10-11^{\text {a }}$ costelas

$\mathrm{R}^{2}$ : Coeficiente de correlação

Syx: Desvio padrão da estimativa

Para a estimativa dos teores de proteína e cinzas no corpo vazio foram utilizadas as relações proteína:água de 0,2806 e cinzas:água de 0,0649 ,calculadas para tourinhos Brangus por ALLEONI et al. (2001), e as relações proteína:água de 0,3077 e cinzas:água de 0,0739, calculadas para tourinhos Nelore através dos dados de LANNA (1988).

\subsection{Estimativa da energia líquida depositada}

Os ganhos de peso do corpo vazio (PCVz) e dos componentes químicos do corpo vazio foram calculados com os valores estimados para esses parâmetros para cada animal no início do período de alimentação e os valores determinados após o abate de cada animal no final do período de alimentação.

Os valores de energia dos ingredientes da ração foram determinados por ensaio de digestibilidade.

As quantidades de energia e proteína no ganho de peso vazio foram estimadas a partir da composição corporal dos animais estimada no início e no final do confinamento.

O cálculo da energia retida (ER) foi realizado considerando valores médios (dos trabalhos de Reid et al., 1968; e Garret e Hinman, 1969) apresentados pelo ARC (1980). Para o extrato etéreo o valor é de 9,442 $\mathrm{kcal} / \mathrm{g}$, e para proteína é de $5,493 \mathrm{kcal} / \mathrm{g}$. 


\subsection{Ensaio de digestibilidade}

\subsubsection{Animais}

Para estimar a ingestão e o teor de energia metabolizável das dietas foi conduzido um ensaio de digestibilidade com quatro animais Nelore e quatro Brangus.

\subsubsection{Procedimentos}

O teor de energia metabolizável (EM) das rações foi obtido considerando-se que $1 \mathrm{~kg}$ de NDT contém 4,409 Mcal de energia digestível (ED) e o fator 0,82 para a conversão de ED em EM (NRC, 1996).

No ensaio de digestibilidade foi realizada a coleta total de fezes dos animais, que foram alojados em gaiolas metabólicas.

Os animais receberam água e alimento ad libitum durante o período de adaptação de cinco dias, onde foram mensurados o alimento fornecido e as sobras. De acordo com o consumo, o fornecimento foi ajustado de modo a não se obter sobra durante o período de colheita. A colheita de fezes foi realizada durante cinco dias consecutivos. As amostras de fezes foram homogeneizadas, acondicionadas em sacos plásticos e congeladas para análises químicas posteriores. No mesmo período de colheita das fezes, foi feita amostragem do alimento total oferecido e das sobras. As amostras do alimento e da sobra também foram congeladas para análises.

Após o descongelamento, as amostras foram secas em estufa com circulação forçada de ar a $60^{\circ} \mathrm{C}$, durante 48 horas, sendo, posteriormente, moídas em peneira de $2 \mathrm{~mm}$, retirando-se uma subamostra para análise dos nutrientes: matéria seca $(M S)$, proteína bruta $(\mathrm{PB})$, fibra bruta $(\mathrm{FB})$, extrato etéreo $(E E)$, matéria mineral $(M M)$, fibra em detergente neutro (FDN) e fibra em detergente ácido (FDA), conforme SILVA (1998). Na análise da FDN não foram extraídos o nitrogênio e as cinzas.

Os valores do extrativo não nitrogenado (ENN) foram obtidos pela fórmula:

$M S-(P B+F B+E E+M M)$. 
Para o cálculo dos nutrientes digestíveis totais (NDT) foi utilizada a seguinte fórmula:

$$
\text { NDT }(\%)=\% \text { PBd }+\% F B d+\% E N N d+(\% E E d X 2,25)
$$

Onde: $d$ indica porção digestível do nutriente.

A matéria orgânica $(\mathrm{MO})$ foi determinada pela diferença entre a MS e a MM.

\subsection{Modelos matemáticos}

\subsubsection{Delineamento experimental do confinamento}

O delineamento experimental do experimento foi inteiramente casualizado em arranjo fatorial $2 \times 4$ (raças Nelore e Brangus, e quatro porcentagens de concentrado na dieta, 20, 40, 60 e $80 \%$ ), com seis repetições.

\subsubsection{Delineamento experimental do ensaio de digestibilidade}

O delineamento do ensaio de digestibilidade foi composto de dois quadrados latinos $4 \mathrm{X} 4$ (cada quadrado latino composto por uma raça). Dentro de cada quadrado quatro animais receberam dietas com quatro níveis de concentrados $(20,40,60$ e $80 \%)$, por quatro períodos compostos de cinco dias de adaptação e cinco dias de colheita.

\subsubsection{Desempenho animal e características de carcaça}

O estudo da ingestão de alimentos, ganho de peso e das taxas de deposição de tecidos obedeceu ao seguinte modelo matemático:

$Y i j k=\mu+R i+T j+R T i j+e i j k$

Onde:

$$
\begin{aligned}
& \begin{array}{l}
\text { Yijk }= \\
\text { k-ésima observação referente ao j-ésimo tratamento e } \\
\quad \text { i-ésimo grupo genético }
\end{array} \\
& \mu=\text { média geral } \\
& \mathrm{Ri}=\text { efeito do i-ésimo grupo genético (Nelore e Brangus) } \\
& \mathrm{Tj}=\text { efeito do j-ésimo tratamento }(20 \%, 40 \%, 60 \% \text { e } 80 \% \text { de } \\
& \text { concentrados) }
\end{aligned}
$$




$$
\begin{aligned}
& \text { RTij = efeito da interação entre o i-ésimo grupo genético e o j- } \\
& \text { ésimo tratamento } \\
& \text { eijk = erro inerente a cada observação } \sim \operatorname{NID~}\left(0, \delta^{2} e\right) \\
& \text { As análises estatísticas foram feitas com o programa SAS (1989). }
\end{aligned}
$$




\section{RESULTADOS}

\subsection{Ensaio de digestibilidade}

Os coeficientes de digestibilidade da matéria seca (MS), proteína bruta $(\mathrm{PB})$, extrato etéreo $(\mathrm{EE})$, fibra bruta $(\mathrm{FB})$, fibra em detergente neutro (FDN), fibra em detergente ácido (FDA), matéria mineral (MM), extrativonão-nitrogenado (ENN) matéria orgânica $(\mathrm{MO})$, o teor de nutrientes digestíveis totais (NDT), a concentração de energia digestível (ED) e energia metabolizável (EM) na dieta, e a porcentagem de consumo de MS em função do peso vivo estão apresentados na Tabela 3.

Para a análise de regressão foram selecionados os parâmetros que apresentaram diferença significativa a 1 ou $5 \%$ entre as proporções de concentrado ou na interação entre raças e níveis de concentrado na dieta.

O coeficiente de digestibilidade da MS apresentou tendência de diferença entre raças $(P=0,05)$. Para a $P B$ e $M M$ houve diferença $(P<0,02)$ entre raças, com os maiores valores para a raça Brangus. A PB apresentou interação entre raças e proporções de concentrado, e o desmembramento da interação mostrou efeito da dieta apenas para a raça Brangus $(P=0,02)$, com comportamento linear na análise de regressão $(P<0,01)$.

Para a FB houve diferença entre os níveis de concentrado na dieta $(P<0,01)$, e a análise de regressão indicou comportamento cúbico $(P=0,04)$, com as maiores médias alcançadas no tratamento com $40 \%$ de concentrado para ambas as raças.

Para a FDN, ED e EM houve diferença apenas entre níveis de concentrado $(P<0,01)$, com comportamento linear $(P<0,01)$. Os coeficientes de digestibilidade da FDN decresceram e da ED e EM aumentaram com a adição do nível de concentrado na dieta. 
O coeficiente de digestibilidade do ENN tendeu a apresentar interação entre raças e níveis de concentrado $(P=0,05)$, e a separação da interação por raças mostrou tendência de diferenças entre os níveis de concentrado para a raça Brangus $(P=0,08)$, com comportamento linear na análise de regressão $(P=0,02)$, entretanto a equação obtida apresentou um coeficiente de correlação muito baixo $(0,26)$, e portanto não foi considerada.

$O$ teor de NDT foi diferente entre raças $(P=0,09)$ e níveis de concentrado $(P<0,01)$, que apresentaram comportamento linear crescente $(P<0,01)$.

A porcentagem de consumo de MS foi diferente entre raças $(P<0,01)$, com maiores valores para o Brangus, níveis de concentrado na dieta $(P=0,05)$, e apresentou interação entre as duas variáveis $(P<0,01)$. Para a raça Brangus o comportamento foi linear crescente $(P<0,01)$ e para o Nelore foi quadrático $(P<0,01)$, com maior consumo para o tratamento com $40 \%$ de concentrado na dieta.

As equações de regressão obtidas para cada um dos parâmetros do ensaio de digestibilidade estão apresentadas na Tabela 4. 
Tabela 3. Coeficientes de digestibilidade da matéria seca (MS), proteína bruta (PB), extrato etéreo (EE), fibra bruta (FB), fibra em detergente neutro (FDN), fibra em detergente ácido (FDA), matéria mineral (MM), extrativo não-nitrogenado (ENN) e matéria orgânica (MO); nutrientes digestíveis totais (NDT), energia digestível (ED), energia metabolizável (EM) e consumo de MS diário em porcentagem do peso vivo (CMS) das dietas experimentais para animais Brangus e Nelore.

\begin{tabular}{|c|c|c|c|c|c|c|c|c|c|c|c|}
\hline \multirow{3}{*}{ Nutriente } & \multicolumn{8}{|c|}{ Tratamentos (\% de concentrado na dieta) } & \multirow{2}{*}{\multicolumn{2}{|c|}{$\begin{array}{c}\text { Análise Estatística } \\
\text { de } P \text { ) }\end{array}$}} & \multirow[t]{2}{*}{ (valor } \\
\hline & \multicolumn{4}{|c|}{ Brangus } & \multicolumn{4}{|c|}{ Nelore } & & & \\
\hline & 20 & 40 & 60 & 80 & 20 & 40 & 60 & 80 & Raça $^{a}$ & Conc. $^{b}$ & $R X C^{c}$ \\
\hline MS (\%) & 58,41 & 61,89 & 66,58 & 68,53 & 60,59 & 62,69 & 58,44 & 55,53 & 0,051 & & 0,069 \\
\hline PB (\%) & 64,96 & 71,30 & 73,39 & 78,11 & 68,66 & 70,90 & 65,19 & 62,83 & 0,019 & 0,451 & 0,013 \\
\hline EE (\%) & 57,40 & 67,51 & 62,40 & 70,19 & 64,47 & 59,69 & 57,69 & 60,09 & 0,272 & 0,709 & 0,325 \\
\hline FB (\%) & 62,62 & 71,63 & 60,94 & 59,70 & 64,16 & 66,65 & 58,83 & 54,90 & 0,253 & 0,006 & 0,700 \\
\hline FDN (\%) & 52,49 & 53,63 & 47,71 & 43,24 & 56,79 & 53,47 & 47,07 & 41,15 & 0,886 & 0,005 & 0,810 \\
\hline FDA (\%) & 48,31 & 55,44 & 49,50 & 49,63 & 49,75 & 50,84 & 47,54 & 40,56 & 0,158 & 0,170 & 0,490 \\
\hline MM (\%) & 47,34 & 47,28 & 53,57 & 61,20 & 42,08 & 39,15 & 44,45 & 42,49 & 0,003 & 0,211 & 0,462 \\
\hline ENN (\%) & 60,21 & 60,10 & 70,00 & 69,21 & 63,32 & 65,65 & 60,85 & 58,11 & 0,240 & 0,746 & 0,049 \\
\hline MO (\%) & 60,95 & 65,04 & 69,27 & 70,49 & 64,43 & 66,33 & 61,79 & 59,00 & 0,103 & 0,729 & 0,059 \\
\hline NDT (\%) & 59,47 & 62,37 & 68,05 & 71,13 & 63,58 & 65,86 & 66,47 & 74,98 & 0,092 & $<0,001$ & 0,439 \\
\hline CMS (\% /dia) & 1,68 & 1,79 & 1,86 & 1,91 & 1,31 & 1,50 & 1,33 & 1,19 & $<0,001$ & 0,055 & 0,002 \\
\hline ED (Mcal/kg MS) & 2,62 & 2,75 & 2,98 & 3,13 & 2,80 & 2,79 & 2,93 & 3,30 & 0,123 & $<0,001$ & 0,381 \\
\hline EM (Mcal/kg MS) & 2,15 & 2,26 & 2,44 & 2,57 & 2,30 & 2,30 & 2,40 & 2,71 & 0,120 & $<0,001$ & 0,381 \\
\hline
\end{tabular}

a: Diferença estatística entre raças.

b: Diferença estatística entre níveis de concentrado na dieta.

c: Diferença estatística na interação entre raças e níveis de concentrado na dieta. 
CARDOSO et al. (2000) trabalharam com animais F1 Limousin $X$ Nelore alimentados com níveis de concentrado de 25 a $75 \%$, e não observaram diferenças para o consumo em \% PV. Os valores encontrados foram abaixo dos obtidos neste trabalho para a raça Brangus e acima da raça Nelore. CARVALHO et al. (1997) não observaram diferenças no consumo de MS para animais zebuínos alimentados com proporções de concentrado entre 20 e 70\% na dieta. Entretanto, DIAS (1999) e LADEIRA (1998) encontraram aumentos lineares no consumo de MS, comportamento semelhante ao observado para a raça Brangus.

TIBO et al. (2000) trabalharam com animais F1 Simental X Nelore alimentados com 25 a $75 \%$ de concentrado e observaram comportamento linear para o consumo de MS.

GESUALDI JR. (1999), observou comportamento quadrático para o consumo de MS por animais F1 Limousin X Nelore, semelhante ao comportamento observado para a raça Nelore.

OLIVEIRA et al. (1994) analisaram o consumo em \%PV de animais de vários grupos genéticos, e constataram tendência de menor consumo da raça Nelore quando comparada a animais mestiços. Segundo GALVÃO et al. (1991), o menor consumo alimentar de animais Nelore pode indicar menores exigências nutricionais associadas ao menor potencial de ganho de peso diário em relação aos mestiços.

GONÇALVES et al. (1991a) não encontraram diferenças significativas de consumo entre animais Nelore, mestiços Holandês $X$ zebu e búfalos, embora os Nelore e búfalos tenham apresentado consumo $20 \%$ inferior aos mestiços.

Os valores encontrados neste trabalho para a MS e MO (Tabela 3), não estão de acordo com os obtidos por CARDOSO et al. (2000), que observaram acréscimos lineares na digestibilidade da MS, MO, PB, EE e $\mathrm{CHO}$ (carboidratos totais) de novilhos F1 Limousin X Nelore alimentados com $25 ; 37,5 ; 50 ; 62,5$ ou $75 \%$ de concentrado na dieta. Também não observaram influência dos tratamentos sobre a digestibilidade da FDN, 
enquanto neste trabalho constatamos comportamento linear decrescente com o acréscimo de concentrado na dieta.

RESENDE et al. (2001), trabalhando com novilhos mestiços alimentados com dietas com 15, 30, 45, 60 e 75\% de concentrado na dieta observaram efeito quadrático para a digestibilidade da MS, MO, FDN, PB e EB (energia bruta).

VALADARES FILHO et al. (1987) também encontraram resposta quadrática para a digestibilidade da MS e MO. Estes mesmos autores afirmaram que carboidratos não-estruturais possuem coeficiente de digestibilidade aparente total acima de $90 \%$ e carboidratos estruturais próximos de $50 \%$, o que reflete na maior digestão da MS nas rações com menores teores de carboidratos estruturais de maior teor de concentrado.

RODE et al. (1985) apresentaram conclusão semelhante utilizando níveis de concentrado na dieta. Os valores de digestibilidade da MS e MO elevaram-se à medida que aumentou o concentrado na dieta, provavelmente em virtude da redução de carboidratos estruturais e do aumento no teor de carboidratos não-estruturais na dieta. Apesar de não terem sido encontradas diferenças estatísticas entre níveis de concentrado na dieta para a digestibilidade da MS e da MO, resultados semelhantes aos de RODE et al. (1985) foram obtidos para os animais da raça Brangus.

BERCHIELLI (1994) comparou 20 e $60 \%$ de concentrado na dieta e encontrou valores de 50,5 e $61,3 \%$ de digestibilidade da MS e 52 e $62,8 \%$ de digestibilidade da $\mathrm{MO}$, respectivamente. valores abaixo dos encontrados neste trabalho tanto para a raça Brangus quanto para a Nelore.

BURGER et al. (2000) verificaram efeito linear crescente na digestibilidade aparente da MS e MO ao variar níveis de concentrado de 30 a $90 \%$ na dieta.

LANÇANOVA et al. (2001) forneceram dietas com 55\% de concentrado a animais de diferentes grupos genéticos (Gir, Nelore, Guzerá, Santa Gertrudis e Caracu) e avaliaram os coeficientes de digestibilidade dos nutrientes por coleta total de fezes. As digestibilidades de MS, MO, EB e NDT foram semelhantes entre os grupos genéticos. LORENZONI et al. 
(1986) citam que existe uma semelhança entre zebuínos e taurinos em relação a digestibilidade da MS e EB. A semelhança de digestibilidade de nutrientes entre animais zebuínos e mestiços taurinos foi observada neste trabalho com animais Nelore e Brangus, exceto para a PB, MM e NDT.

OLIVEIRA et al. (1994) encontraram valores médios de digestibilidade da MS e MO semelhantes entre rações com 30 e 50\% de concentrado, para animais da raça Nelore e mestiços Nelore $X$ europeu.

Porém, RODRÍGUEZ et al. (1997), constataram maior coeficiente de digestibilidade $(P<0,05)$ da MS e MO para animais Holandês em relação ao Nelore.

Os aumentos verificados nos coeficientes de digestibilidade da MS, MO e EB dos trabalhos citados podem ser explicados pela elevação do conteúdo celular juntamente com a redução da parede celular (FDA), à medida que se elevou a proporção de concentrado na dieta (LIMA, 1986).

Quanto a digestibilidade da FDN, foi observado um decréscimo linear, que de acordo com RESENDE et al. (2001), é explicado pelo efeito depressor do concentrado sobre a digestibilidade da fibra. Os resultados obtidos foram semelhantes aos de ARAÚJO et al. (1998), que forneceram de 10 a $90 \%$ de concentrado na dieta e verificaram decréscimo linear na digestibilidade da FDN com o aumento dos níveis de concentrado.

Porém, BURGER et al. (2000) e BERCHIELLI (1994) não verificaram efeitos dos níveis de concentrado sobre a digestibilidade da FDN.

Para a FDA, ARAÚJO et al. (1998) observaram efeito quadrático dos níveis de concentrado sobre a digestibilidade, sendo o valor máximo obtido quando foi fornecido $29 \%$ de concentrado na dieta. Entretanto RODRIGUEZ et al. (1996) não observaram diferenças na digestibilidade da FDA, com valor médio de 49,5\%. Estes mesmos autores também não encontraram diferenças na digestibilidade da PB ao oferecer dietas com 12,5 a $50 \%$ de concentrado, assim como neste trabalho.

Entretanto, LIMA (1986) encontrou maior digestibilidade da PB para a ração com maior proporção de concentrado. DIAS (1999) encontrou aumentos lineares na digestibilidade de PB e EE com o aumento dos níveis 
de concentrado na dieta, e atribuiu estes valores à menor proporção endógena a ao aumento no consumo destes nutrientes.

GOMES (1982), encontrou maior digestibilidade da proteína em Holandês que em Nelore e mestiços. Resultados diferentes foram verificados por RODRÍGUEZ et al. (1997) que não encontraram diferenças entre animais Bos taurus taurus (Holandês) e Bos taurus indicus (Nelore) para a digestibilidade da PB. Segundo estes autores, a grande controvérsia na literatura quanto a digestibilidade da proteína entre grupos genéticos, pode estar associada a fatores como características das rações utilizadas, níveis de consumo entre outros fatores.

Tabela 4. Equações de regressão dos coeficientes de digestibilidade dos nutrientes e teores de NDT, \% de consumo de MS em função do peso vivo, ED e EM para as raças Brangus e Nelore em função do nível de concentrado na dieta.

\begin{tabular}{llc}
\hline \multicolumn{1}{c}{ Nutriente } & \multicolumn{1}{c}{ Equação de regressão ${ }^{a}$} & $R^{{ }^{b}}$ \\
\hline PB (\%) raça Brangus & $\mathrm{Y}=0,2077 \mathrm{X}+61,555$ & 0,9662 \\
FB (\%) & $\mathrm{Y}=0,0005 \mathrm{X}^{3}-0,073 \mathrm{X}^{2}+3,4015 \mathrm{X}+20,94$ & 1,0000 \\
FDN (\%) & $\mathrm{Y}=-0,2475 \mathrm{X}+62,32$ & 0,9845 \\
NDT (\%) & $\mathrm{Y}=0,1887 \mathrm{X}+57,05$ & 0,9625 \\
CMS raça Brangus (\%/dia) & $\mathrm{Y}=0,0038 \mathrm{X}+1,62$ & 0,9691 \\
CMS raça Nelore (\%/dia) & $\mathrm{Y}=-0,0002 \mathrm{X}^{2}+0,018 \mathrm{X}+1,0525$ & 0,8444 \\
ED para Nelore (Mcal/kg MS) & $\mathrm{Y}=0,084 \mathrm{X}+2,49$ & 0,9333 \\
EM para Nelore (Mcal/kg MS) & $\mathrm{Y}=0,007 \mathrm{X}+2,035$ & 0,9318 \\
\hline
\end{tabular}

a: Os valores de $X$ (níveis de concentrado) para as equações de regressão estão em porcentagem ( $20,40,60$ ou 80$)$.

b: Coeficiente de correlação.

O consumo de MS foi maior para a raça Brangus (variou entre 1,68 e $1,91 \%$ do PV) com comportamento linear na análise de regressão, com maior média para o tratamento com $80 \%$ de concentrado. Os valores para a raça Nelore variaram entre 1,19 e $1,50 \%$ do PV, e apresentaram comportamento quadrático com maior média para o tratamento com $40 \%$ de concentrado. O menor consumo pelo Nelore possivelmente pode ter sido causado pela menor exigência nutricional da raça quando comparada ao Brangus.

Os coeficientes de digestibilidade da MS, EE, FDA, ENN e MO não apresentaram diferenças entre raças ou níveis de concentrado na dieta. $A$ $\mathrm{PB}$ e $\mathrm{MM}$ foram diferentes entre raças. $\mathrm{A} F B$, FDN, ED e EM foram 
diferentes apenas entre os níveis de concentrado na dieta. E o NDT e consumo de MS foram diferentes entre raças e dietas, com interação significativa entre as variáveis no consumo. Vale notar que os animais da raça Nelore apresentaram menor consumo de MS, porém maior porcentagem de NDT em relação aos Brangus.

\subsection{Análises de glicose no plasma sanguíneo}

Os valores de glicose no sangue dos animais (Gráfico 1) não foram significativamente diferentes entre raças, níveis de concentrado na dieta, e não houve interação entre as variáveis.

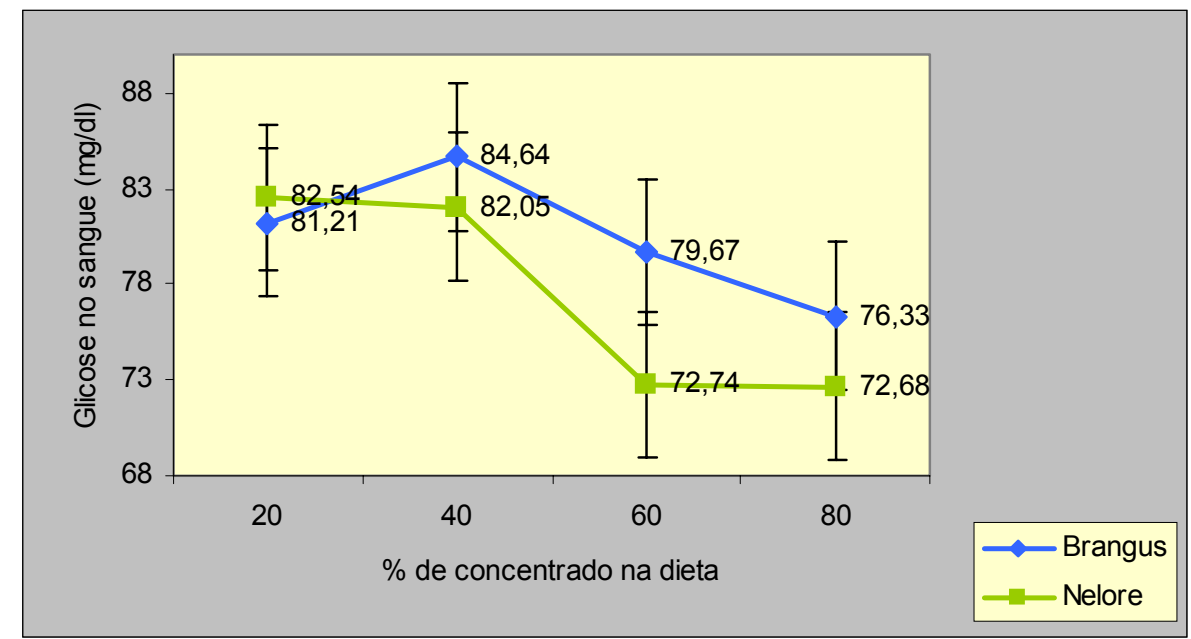

Gráfico 1. Valores de glicose sanguínea dos animais.

Os resultados de glicose encontrados estão dentro dos padrões normais, indicados por DUKES (1996), que cita valores de 40 a $80 \mathrm{mg} / \mathrm{dl} \mathrm{em}$ bovinos adultos e 80 a $120 \mathrm{mg} / \mathrm{dl}$ em bovinos jovens.

\subsection{Análises de uréia no soro sanguíneo}

Os valores de uréia no sangue dos animais estão apresentados no Gráfico 2, e não foram significativamente diferentes entre raças, níveis de concentrado na dieta e não houve interação entre as variáveis. 


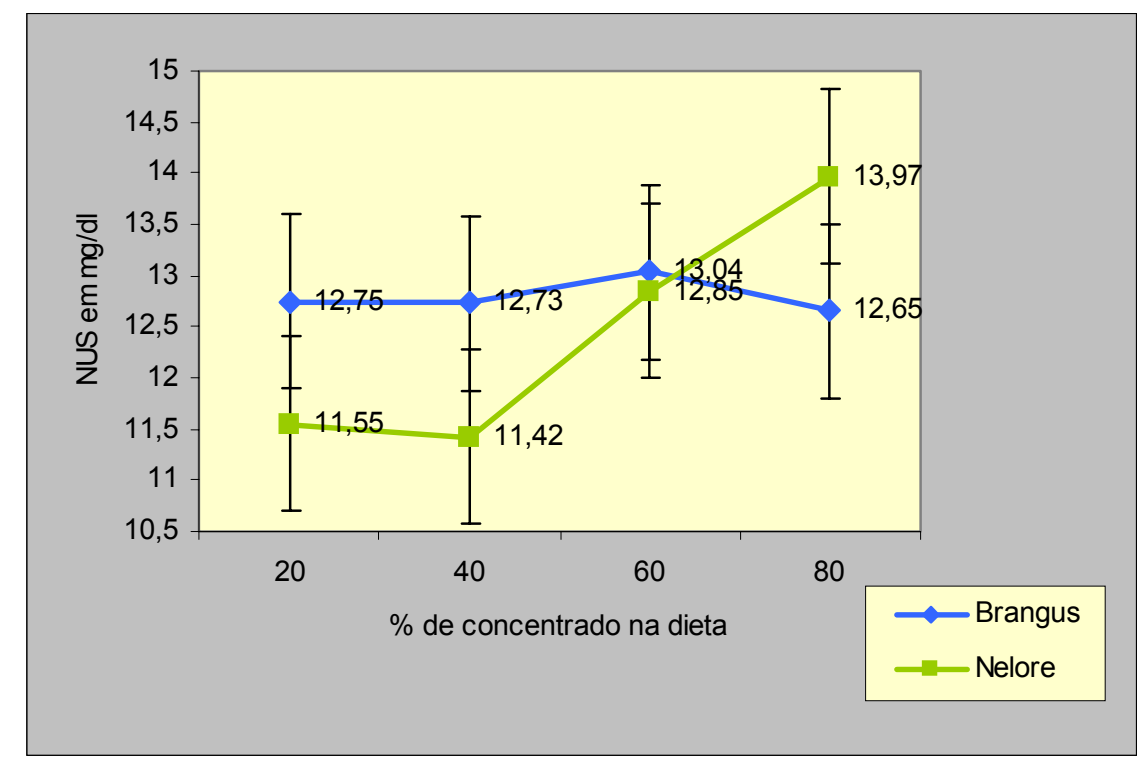

Gráfico 2. Valores de nitrogênio originário da uréia sanguínea (NUS) dos animais.

A uréia é a forma primária de excretar nitrogênio em mamíferos e a concentração de uréia no sangue reflete a utilização de proteína bruta dietética em ruminantes. A concentração de uréia pode ser usada para monitorar a ingestão de proteína bruta, que deve ser o mais próximo possível das necessidades do animal. O excesso de nitrogênio pode prejudicar o desempenho reprodutivo e aumentar as exigências de energia, uma vez que, são necessárias 13,3 kcal de energia digestível para excretar um grama de nitrogênio. Além disso, os suplementos protéicos são caros e uma grande quantidade de nitrogênio excretado gera um impacto ambiental negativo (BRODERICK e CLAYTON, 1997).

A amônia que não é utilizada pelos microrganismos é absorvida pela parede do rúmen (NOLAN, 1993) e vai ao fígado pela circulação sanguínea onde entra no ciclo da uréia (COELHO da SILVA e LEÃO, 1979). No ciclo da uréia, a amônia reage com $\mathrm{CO}_{2}$ mitocondrial para formar carbamilfosfato, na presença de carbamilfosfato-sintetase. Apenas metade do nitrogênio uréico é originário da amônia livre, o restante do nitrogênio é proveniente do aspartato citoplasmático que, por sua vez, atua como doador específico de nitrogênio na conversão da citrulina em arginina (LOBLEY et al., 1995).

Segundo KUNKLE e HOPKINS (1999), apenas uma porção da adição extra de nitrogênio na alimentação é retido como ganho de peso adicional, e 
o restante é metabolizado em uréia, aumentando as concentrações séricas. Desta forma, o NUS é utilizado como indicativo do balanço protéico, sendo que os limites que indicam a adequada ingestão protéica são de 9 a 12 $\mathrm{mg} / \mathrm{dl}$ (HAMOND et al., 1993). No experimento realizado, encontramos valores um pouco acima de $12 \mathrm{mg} / \mathrm{dl}$ para a raça Brangus e para a raça Nelore alimentada com 60 ou $80 \%$ de concentrado. Entretanto, estes valores são considerados normais por DUKES (1996), que cita de 10 a $30 \mathrm{mg} / \mathrm{dl}$ de NUS para bovinos. Assim, de acordo com os resultados observados, é possível imaginar que os animais receberam dietas que atendiam às exigências protéicas. Entretanto, esta afirmação não pode ser comprovada, já que o tipo de análise realizada não nos permite saber se o NUP foi originado do excesso de proteína degradável no rúmen ou do excesso de aminoácidos absorvidos pelo intestino e metabolizados no fígado (LANNA et al., 1998a).

As concentrações de nitrogênio originário da uréia em animais suplementados indicam bom aproveitamento da proteína e da energia. Dietas protéicas com baixa disponibilidade de energia resultam em altas concentrações séricas de nitrogênio originário da uréia, porém ao aumentar a energia na dieta há diminuição nas concentrações sanguíneas de uréia (PITTS et al., 1992). Isso pode explicar o aumento de NUS nos tratamentos com 60 e $80 \%$ de concentrado para os animais da raça Nelore. No Gráfico 1 é possível observar uma queda na concentração de glicose no sangue destes dois grupos, que causaria um aumento do NUS, apesar dos valores de glicose estarem de acordo com DUKES (1996).

VALADARES et al. (1997), encontraram valores semelhantes aos deste experimento de NUS. Trabalhando com novilhos zebus alimentados com rações contendo $45 \%$ de concentrado e teores de proteína bruta variando de 7,0 a 14,5\%, verificaram, por meio de análise de regressão, que a faixa de concentração plasmática de nitrogênio originário da uréia de 13,52 a $15,15 \mathrm{mg} / \mathrm{dl}$ correspondeu à máxima eficiência microbiana e, provavelmente, representaria o limite a partir do qual estaria ocorrendo perda de proteína para esses animais. 


\subsection{Desempenho}

O peso médio final dos animais foi de $400 \mathrm{~kg}$ para a raça Brangus e $361 \mathrm{~kg}$ para a raça Nelore. O ganho de peso em jejum diário (GPJ) foi diferente (Gráfico 3 ) entre raças $(P<0,01)$, com as maiores médias para a raça Brangus. Também houve diferença entre os níveis de concentrado na dieta $(P=0,01)$, com a maior média para a raça Brangus no tratamento com $40 \%$ de concentrado e para a raça Nelore com $60 \%$ de concentrado. $\mathrm{Na}$ análise de regressão, o comportamento dos níveis de concentrado na dieta foi quadrático $(P<0,01)$. Não houve interação entre raças e dietas.

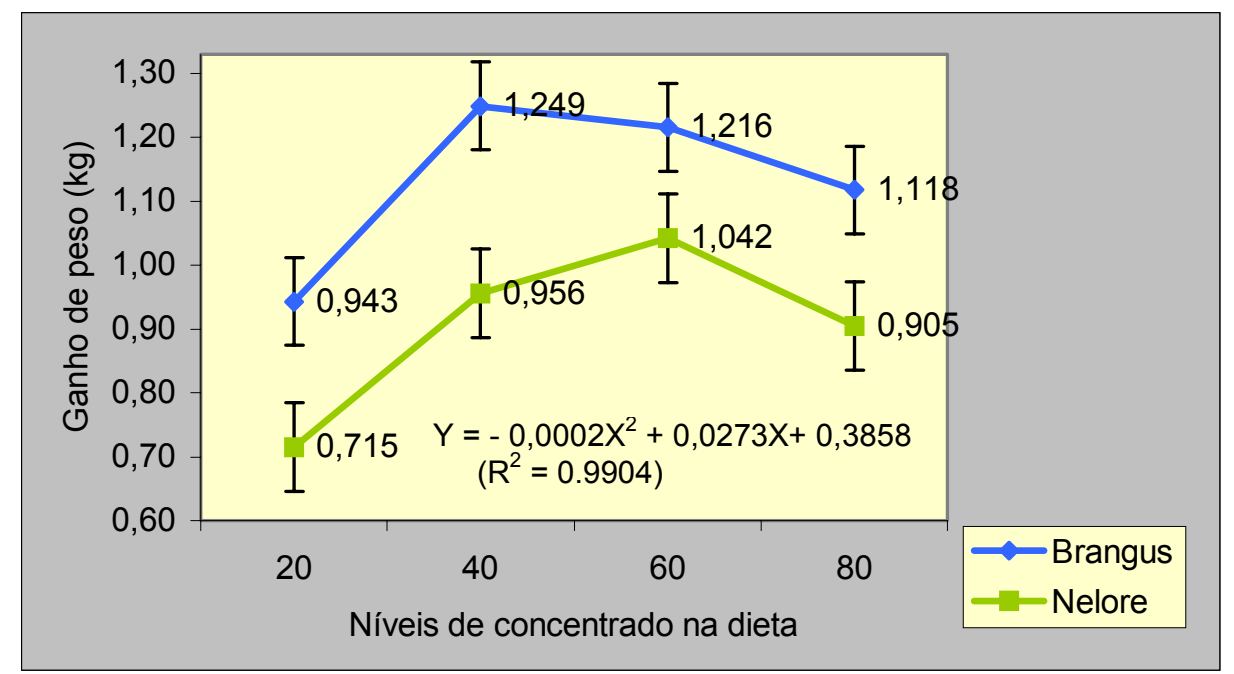

Gráfico 3. Ganho de peso em jejum diário dos animais.

LEME et al. (2001) relataram valores elevados de desempenho para animais da raça Nelore, alimentados com 73,79 e 85\% de concentrado, com um ganho médio diário de 1,461 kg. LEDGER et al. (1970), concluíram que taurinos alimentados à vontade com rações ricas em concentrado foram mais eficazes que zebuínos, resultados semelhantes aos observados neste experimento, em que os animais da raça Brangus apresentaram maiores valores de ganho do que os da raça Nelore.

BULLE et al. (2002a), estudando o desempenho de tourinhos mestiços europeu $X$ zebu (de raça paterna britânica ou continental), alimentados com 70, 85 ou $91 \%$ de concentrado e bagaço de cana-deaçúcar como fonte de volumoso, não encontraram diferenças para as raças quanto ao GPJ. Entretanto, os animais do tratamento com $85 \%$ de 
concentrado foram os que apresentaram maior ganho de peso (1,36 kg/dia). A eficiência alimentar foi semelhante entre os grupos raciais e os tratamentos.

Vários autores constataram um maior ganho médio diário quando utilizaram rações com maior porcentagem de concentrado (BARTLE et al., 1994; FERREIRA, 1997; e OLIVEIRA et al., 1998). Entretanto, a resposta animal à adição de concentrado tende a ser quadrática e não linear (ARAÚJO et al., 1997). Assim, considerando-se o desempenho animal e a eficiência econômica do sistema, o nível ótimo, é variável e tem como fatores determinantes o sexo, a raça e a idade do animal, qualidade do volumoso e concentrado, entre outros (GESUALDI JR et al., 2000).

A ingestão de matéria seca em porcentagem do peso vivo foi diferente para raças $(P=0,05)$ e dietas $(P=0,06)$, apresentando comportamento quadrático na análise de regressão para os níveis de concentrado na dieta (Gráfico 4). Não houve interação entre raças e níveis de concentrado na dieta.

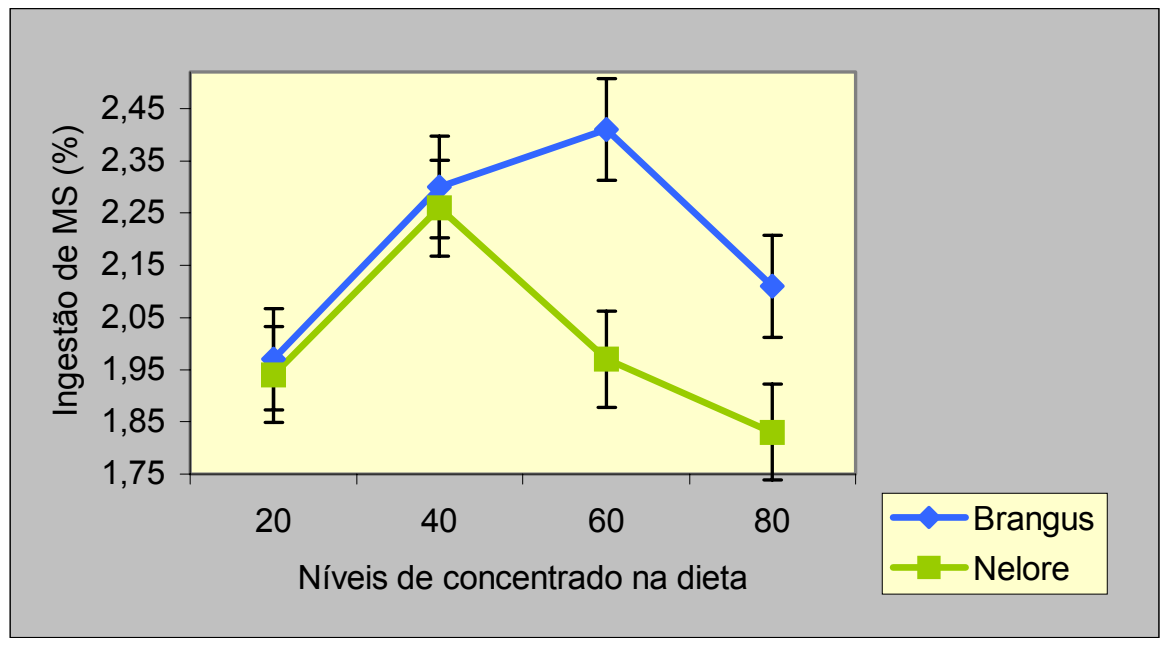

Gráfico 4. Porcentagem de ingestão de matéria seca diária em função do peso vivo dos animais.

Equação de regressão em função dos níveis de concentrado na dieta: $Y=-0,0004 X^{2}+0,0354 X+1,4025\left(R^{2}=0,93\right)$

A curva de ingestão de matéria seca foi crescente para a raça Brangus até o tratamento com $60 \%$ de concentrado, e para a raça Nelore até 
o tratamento com $40 \%$ de concentrado. A partir destes dois pontos, a ingestão começou a declinar.

Para a eficiência alimentar não houve diferença significativa entre raças e proporções de concentrado na dieta (Gráfico 5), porém é possível observar um declínio na eficiência com o aumento da porcentagem de concentrado na dieta para os animais da raça Nelore.

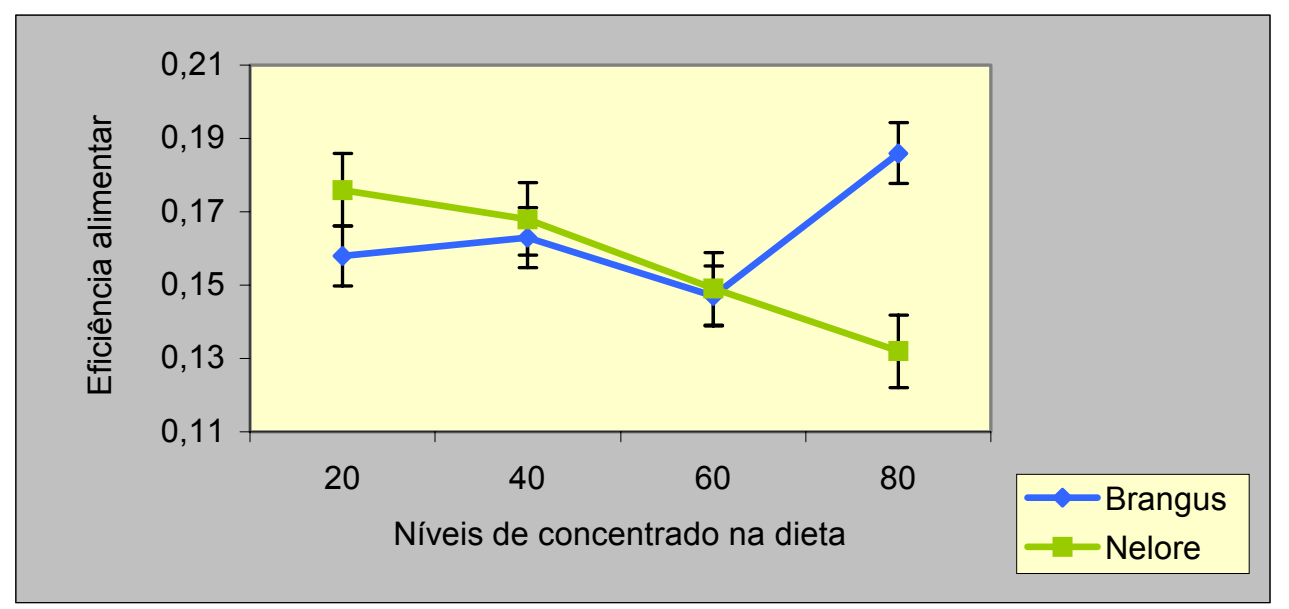

Gráfico 5. Eficiência alimentar dos animais.

A menor ingestão de alimentos pelos animais Nelore tratados com elevadas proporções de concentrado comparados aos Brangus, reafirma resultados obtidos por outros pesquisadores. GONÇALVES et al. (1991a), trabalhando com animais Nelore, Holandês e mestiços, alimentados com 20 e $60 \%$ de concentrados na dieta, observaram que não houve diferença entre os grupos genéticos, embora a raça Nelore tenha apresentado consumo $20 \%$ inferior aos holandeses. OLIVEIRA et al. (1994), observaram menor consumo $(P<0,05)$ por animais Nelore em relação a animais mestiços, quando alimentados com 30 ou $50 \%$ de concentrado. Entretanto, LEME et al. (2001), verificaram tendência de maior ingestão por animais Nelore alimentados com 85 e $79 \%$ de concentrado na matéria seca da dieta quando comparados aos com $73 \%$ de concentrado, mas com dietas em que grande parte do amido foi substituído por pectina.

Resultados semelhantes foram obtidos por BULLE et al. (2002a), que observaram maior consumo de matéria seca $(7,93 \mathrm{~kg} / \mathrm{dia})$ por animais ingerindo $85 \%$ de concentrado quando comparado a animais ingerindo 
dietas com $79 \%$ ou $91 \%$ de concentrado. A menor ingestão foi dos animais que recebiam $91 \%$ de concentrado $(6,85 \mathrm{~kg} / \mathrm{dia})$.

OLIVEIRA et al. (1998), avaliando níveis crescentes de concentrado (25; 37,$5 ; 50 ; 62,5$ e $75 \%$ ) na dieta de bovinos Nelore em confinamento, encontraram resposta quadrática para consumo de matéria seca, sendo o maior alcançado com o nível de $58,47 \%$.

CARVALHO et al. (1996), BURGER et al. (1998) e SIGNORETTI et al. (1998) não verificaram diferenças no consumo de matéria seca ao fornecerem dietas com níveis crescentes de concentrado em substituição ao feno. Por outro lado, FERREIRA (1998b) e LADEIRA et al. (1998) relataram resposta linear para consumo, fornecendo rações com até $75 \%$ de concentrado e feno. Isso mostra que maiores níveis de concentrado na dieta podem não apresentar o resultado esperado. Em alguns casos, ocorreu redução do consumo, como foi observado por EUCLIDES FILHO et al. (1996), que forneceram dietas com 0, 40 e 60\% de concentrado e feno de capim Tanzânia.

Muitas pesquisas têm demonstrado diferenças na taxa de conversão alimentar, a partir de variações no teor energético da ração (EUCLIDES FILHO et al., 1996; FEIJÓ et al., 1996; FERREIRA, 1998b e OLIVEIRA et al., 1998). De acordo com NEUMAN (1977), uma maior densidade energética resulta em maior ingestão de energia, e assim menos alimento é requerido para o ganho.

A ingestão de proteína também pode influenciar no consumo de matéria seca. PETIT et al. (1994) observaram que a suplementação protéica de dietas à base de silagens resultou em aumento no consumo de matéria seca e ganho médio diário de peso vivo, além de redução na conversão alimentar, em comparação à suplementação exclusiva de energia. SALOMONI et al. (1980) não encontraram diferenças no ganho médio diário de peso vivo de novilhos azebuados recebendo níveis crescentes de energia durante a fase de terminação. ALVES et al. (1998) também não verificaram diferenças no consumo de matéria seca, na conversão alimentar e no ganho médio diário de peso vivo, ao fornecerem duas dietas com silagem de milho 
a novilhos zebu e mestiços, mesmo com diferenças de $0,270 \mathrm{~kg}$ de proteína bruta entre as dietas.

Vários estudos realizados no Brasil têm mostrado diferenças no consumo de alimento, no ganho de peso vivo, e na conversão alimentar entre Bos taurus taurus, Bos taurus indicus e seus mestiços (GALVÃO et al., 1991; GONÇALVES et al., 1991a; e EUCLIDES FILHO et al., 1996).

Neste trabalho foi possível observar que a raça Nelore apresentou menores ganhos de peso diários e menor consumo de matéria seca em relação ao Brangus. A queda mais acentuada no consumo pelo Nelore foi pelos animais alimentados com 60 e $80 \%$ de concentrado. Entretanto, as eficiências alimentares das duas raças são semelhantes, mantendo-se muito próximas até o nível de $60 \%$ de concentrado na dieta.

\subsection{Composição corporal}

Não houve interação significativa entre raças e proporções de concentrado na dieta para nenhum dos parâmetros de composição corporal analisados. Os valores dos parâmetros relativos ao início do experimento (peso vazio, peso da carcaça quente, água, extrato etéreo, proteína, cinzas e energia iniciais) foram estimados a partir dos valores obtidos com os animais da linha base.

Para a análise de regressão foram selecionadas as variáveis que apresentaram diferença significativa a 1 ou $5 \%$ entre níveis de concentrado.

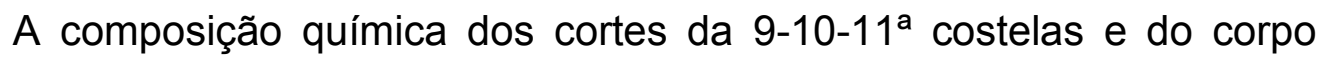
vazio dos animais da linha base e que passaram pelo período experimental estão descritos na Tabela 5. O peso vivo em jejum final, peso vazio final, ganho de peso vazio, peso da carcaça quente final e ganho de peso de carcaça quente foram diferentes entre raças $((P<0,05)$, com as maiores médias para a raça Brangus) e níveis de concentrado, que apresentaram comportamento quadrático na análise de regressão $(P<0,01)$. As porcentagens dos nutrientes no corpo vazio foram diferentes apenas entre raças $\mathrm{P}(<0,01)$, com maiores médias de água, proteína e cinzas para a raça Nelore, de extrato etéreo e energia para a raça Brangus. 
As quantidades de água, de gordura, de proteína e de cinzas do corpo vazio no início e no final do experimento encontram-se na Tabela 6. As quantidades iniciais dos nutrientes foram diferentes apenas entre raças $(P \leq 0,05)$, com maiores médias de água, proteína e cinzas para o Nelore, e de extrato etéreo e energia para o Brangus. As quantidades finais dos nutrientes foram diferentes entra raças (exceto para a água) e níveis de concentrado (com comportamento quadrático $(\mathrm{P}<0,01)$ para todas as variáveis analisadas). As quantidades de extrato etéreo e energia foram maiores para a raça Brangus, e de proteína e cinzas para a Nelore.

$\mathrm{Na}$ Tabela 7 estão os valores das taxas de deposição dos nutrientes. As deposições de extrato etéreo e energia foram diferentes entre raças $((P<0,01)$ com as maiores médias para o Brangus $)$ e entre níveis de concentrado (comportamento quadrático $\mathrm{P}<0,01$ na análise de regressão). As quantidades de água, proteína e cinzas depositadas foram diferentes apenas entre níveis de concentrado, que apresentaram comportamento quadrático $(\mathrm{P}<0,01)$. A composição do ganho de peso vazio foi diferente entre raças, com maiores médias para o Brangus de extrato etéreo e energia no ganho de peso vazio. A raça Nelore apresentou as maiores médias para as porcentagens de água, proteína, cinzas e proteína em kg/kg.

As equações de regressão referentes a cada um dos parâmetros que apresentaram diferenças significativas para dietas em função dos níveis de concentrado estão descritas na Tabela 8.

Na Tabela 9 está apresentada a correlação entre a composição do corpo vazio e composição do ganho de peso vazio. 
Tabela 5. Peso vivo em jejum, peso vazio, peso de carcaça quente, ganhos de peso e composição dos cortes da 9-10-11'a costelas.

\begin{tabular}{|c|c|c|c|c|c|c|c|c|c|c|c|}
\hline \multirow[t]{3}{*}{ Item } & \multicolumn{8}{|c|}{ Tratamentos (\% de concentrado na dieta) } & \multirow{2}{*}{\multicolumn{3}{|c|}{$\begin{array}{c}\text { Análise } \\
\text { Estatística (valor de } P \text { ) }\end{array}$}} \\
\hline & \multicolumn{4}{|c|}{ Brangus } & \multicolumn{4}{|c|}{ Nelore } & & & \\
\hline & $20 \%$ & $40 \%$ & $60 \%$ & $80 \%$ & $20 \%$ & $40 \%$ & $60 \%$ & $80 \%$ & $R^{a}$ & $C^{b}$ & $R X C^{c}$ \\
\hline Período de confinamento (dias) & 145 & 145 & 145 & 145 & 145 & 145 & 145 & 145 & - & - & - \\
\hline Peso vivo jejum inicial (kg) & 230,3 & 243,2 & 254,2 & 224,2 & 237,7 & 230,0 & 222,3 & 232,8 & 0,310 & 0,778 & 0,162 \\
\hline Peso vivo jejum final (kg) & 367,1 & 424,2 & 430,5 & 386,2 & 341,4 & 368,7 & 373,4 & 364,1 & $<0,001$ & 0,008 & 0,474 \\
\hline Ganho peso vivo jejum (kg/dia) & 0,943 & 1,249 & 1,216 & 1,118 & 0,715 & 0,956 & 1,042 & 0,905 & 0,001 & 0,010 & 0,9357 \\
\hline Peso vazio inicial (kg) & 200,8 & 212,0 & 221,6 & 195,4 & 212,4 & 205,6 & 198,7 & 208,1 & 0,848 & 0,788 & 0,162 \\
\hline Peso vazio final (kg) & 309,9 & 363,8 & 372,5 & 328,4 & 301,2 & 328,8 & 331,4 & 324,0 & 0,018 & 0,003 & 0,389 \\
\hline Ganho peso vazio (kg/dia) & 0,753 & 1,047 & 1,041 & 0,917 & 0,612 & 0,849 & 0,915 & 0,799 & 0,016 & 0,003 & 0,961 \\
\hline Peso carcaça quente inicial (kg) & 126,4 & 133,4 & 139,5 & 123,0 & 134,4 & 130,1 & 125,8 & 131,7 & 0,988 & 0,790 & 0,162 \\
\hline Peso carcaça quente final (kg) & 200,7 & 237,0 & 242,9 & 213,2 & 196,3 & 215,3 & 217,1 & 212,0 & 0,037 & 0,003 & 0,403 \\
\hline Ganho peso carcaça quente (kg/dia) & 0,512 & 0,714 & 0,714 & 0,622 & 0,427 & 0,587 & 0,630 & 0,554 & 0,024 & 0,003 & 0,954 \\
\hline \multicolumn{12}{|c|}{ Composição 9-10-11a costelas } \\
\hline$\%$ água & 56,94 & 56,66 & 53,93 & 55,09 & 56,81 & 55,66 & 56,26 & 56,58 & 0,346 & 0,370 & 0,348 \\
\hline$\%$ extrato etéreo & 20,91 & 21,28 & 25,07 & 22,38 & 22,50 & 23,57 & 22,44 & 22,00 & 0,774 & 0,272 & 0,107 \\
\hline \multicolumn{12}{|c|}{ Composição do corpo vazio } \\
\hline \% água & 58,54 & 58,24 & 55,45 & 56,64 & 61,54 & 60,79 & 61,18 & 61,39 & $<0,001$ & 0,233 & 0,220 \\
\hline$\%$ extrato etéreo & 21,08 & 21,43 & 24,74 & 23,33 & 17,11 & 18,01 & 17,05 & 16,73 & $<0,001$ & 0,347 & 0,108 \\
\hline \% proteína & 16,42 & 16,34 & 15,56 & 15,89 & 18,93 & 18,70 & 18,82 & 18,89 & $<0,001$ & 0,260 & 0,241 \\
\hline$\%$ cinzas & 3,80 & 3,78 & 3,60 & 3,67 & 4,55 & 4,49 & 4,52 & 4,54 & $<0,001$ & 0,273 & 0,259 \\
\hline Energia (Mcal/kg) & 2,89 & 2,92 & 3,19 & 3,07 & 2,66 & 2,73 & 2,64 & 2,61 & $<0,001$ & 0,388 & 0,107 \\
\hline
\end{tabular}

a: Diferença estatística entre raças.

b: Diferença estatística entre níveis de concentrado na dieta.

c: Diferença estatística na interação entre raças e níveis de concentrado na dieta. 
Tabela 6. Composição química do corpo vazio dos animais no início e no final do experimento.

\begin{tabular}{|c|c|c|c|c|c|c|c|c|c|c|c|}
\hline \multirow[t]{3}{*}{ Item } & \multicolumn{8}{|c|}{ Tratamentos (\% de concentrado na dieta) } & \multirow{2}{*}{\multicolumn{3}{|c|}{$\begin{array}{c}\text { Análise } \\
\text { Estatística (valor de } P \text { ) }\end{array}$}} \\
\hline & \multicolumn{4}{|c|}{ Brangus } & \multicolumn{4}{|c|}{ Nelore } & & & \\
\hline & $20 \%$ & $40 \%$ & $60 \%$ & $80 \%$ & $20 \%$ & $40 \%$ & $60 \%$ & $80 \%$ & $R^{a}$ & $C^{b}$ & $R \times C^{C}$ \\
\hline \multicolumn{12}{|c|}{ Composição inicial } \\
\hline Água (kg) & 117,71 & 123,16 & 122,96 & 110,38 & 130,80 & 125,09 & 121,72 & 127,77 & 0,050 & 0,753 & 0,285 \\
\hline Extrato etéreo $(\mathrm{kg})$ & 42,11 & 45,77 & 54,69 & 45,92 & 36,39 & 37,00 & 33,82 & 34,87 & $<0,001$ & 0,368 & 0,072 \\
\hline Proteína $(\mathrm{kg})$ & 33,03 & 34,56 & 34,50 & 30,97 & 40,25 & 38,49 & 37,45 & 39,31 & $<0,001$ & 0,771 & 0,289 \\
\hline Cinzas (kg) & 7,64 & 7,99 & 7,98 & 7,16 & 9,67 & 9,24 & 9,00 & 9,44 & $<0,001$ & 0,778 & 0,290 \\
\hline Energia (Mcal) & 579,04 & 622,01 & 705,92 & 603,74 & 564,68 & 560,73 & 525,08 & 545,22 & 0,001 & 0,524 & 0,084 \\
\hline \multicolumn{12}{|c|}{ Composição final } \\
\hline Água (kg) & 181,19 & 211,98 & 206,66 & 185,55 & 185,44 & 199,60 & 202,71 & 198,87 & 0,954 & 0,013 & 0,366 \\
\hline Extrato etéreo $(\mathrm{kg})$ & 65,59 & 77,82 & 92,01 & 77,17 & 51,82 & 59,68 & 56,62 & 54,31 & $<0,001$ & 0,021 & 0,155 \\
\hline Proteína (kg) & 50,84 & 59,48 & 57,99 & 52,06 & 57,06 & 61,42 & 62,37 & 61,19 & 0,001 & 0,014 & 0,412 \\
\hline Cinzas (kg) & 11,76 & 13,76 & 13,41 & 12,04 & 13,70 & 14,75 & 14,98 & 14,70 & $<0,001$ & 0,014 & 0,433 \\
\hline Energia (Mcal) & 898,65 & 1061,48 & 1187,30 & 1014,67 & 802,71 & 900,82 & 877,18 & 848,90 & $<0,001$ & 0,01 & 0,245 \\
\hline
\end{tabular}

a: Diferença estatística entre raças.

b: Diferença estatística entre níveis de concentrado na dieta.

c: Diferença estatística na interação entre raças e níveis de concentrado na dieta. 
Tabela 7. Taxa de deposição dos componentes químicos corporais e composição do ganho de peso vazio.

\begin{tabular}{|c|c|c|c|c|c|c|c|c|c|c|c|}
\hline \multirow[t]{3}{*}{ Item } & \multicolumn{8}{|c|}{ Tratamentos (\% de concentrado na dieta) } & \multirow{2}{*}{\multicolumn{3}{|c|}{$\begin{array}{c}\text { Análise } \\
\text { Estatística (valor de } P \text { ) }\end{array}$}} \\
\hline & \multicolumn{4}{|c|}{ Brangus } & \multicolumn{4}{|c|}{ Nelore } & & & \\
\hline & $20 \%$ & $40 \%$ & $60 \%$ & $80 \%$ & $20 \%$ & $40 \%$ & $60 \%$ & $80 \%$ & $R^{a}$ & $C^{b}$ & $R X C^{C}$ \\
\hline \multicolumn{12}{|c|}{ Taxa de deposição } \\
\hline Água (kg/dia) & 0,438 & 0,612 & 0,577 & 0,518 & 0,377 & 0,514 & 0,558 & 0,490 & 0,142 & 0,006 & 0,843 \\
\hline Extrato etéreo (kg/dia) & 0,162 & 0,221 & 0,258 & 0,215 & 0,106 & 0,156 & 0,157 & 0,134 & $<0,001$ & 0,004 & 0,672 \\
\hline Proteína (kg/dia) & 123 & 0,172 & 0,162 & 0,145 & 0,116 & 0,158 & 0,172 & 51 & 0,894 & 0,007 & 0,837 \\
\hline Cinzas (kg/dia) & 028 & 0,040 & 0,038 & 0,034 & 0,028 & 0,038 & 0,041 & 0,036 & 0,688 & 0,007 & 0,860 \\
\hline Energia (Mcal/dia) & 2,204 & 3,031 & 3,320 & 2,834 & 1,642 & 2,345 & 2,428 & 2,094 & $<0,001$ & 0,003 & 0,931 \\
\hline $\mathrm{kg} / \mathrm{dia})$ & 0,753 & 1,047 & 1,041 & 0,917 & 0,612 & 0,849 & 0,915 & 0,799 & 0,016 & 0,003 & 0,961 \\
\hline \multicolumn{12}{|c|}{ Composição do ganho de peso vazio } \\
\hline \% Á & 58,62 & 58,35 & 55,81 & 56,89 & 60,26 & 59,60 & 60,22 & 60,47 & $<0$, & 0,283 & 0,109 \\
\hline$\%$ Extrato etéreo & 21,13 & 21,48 & 24,91 & 23,45 & 16,74 & 17,66 & 16,80 & 16,46 & $<0,001$ & 0,290 & 0,110 \\
\hline \% Proteína & 16,45 & 16,37 & 15,66 & 15,96 & 18,54 & 18,34 & 18,53 & 18,60 & $<0,001$ & 0,302 & 0,112 \\
\hline$\%$ Cinzas & 3,80 & 3,79 & 3,62 & 3,69 & 4,45 & 4,40 & 4,45 & 4,47 & $<0,001$ & 0,320 & 0,115 \\
\hline Energia (Mcal/kg) & 2,89 & 2,92 & 3,19 & 3,07 & 2,66 & 2,73 & 2,64 & 2,61 & $<0,001$ & 0,388 & 0,107 \\
\hline Proteína $(\mathrm{kg} / \mathrm{kg})$ & 0,164 & 0,163 & 0,155 & 0,159 & 0,189 & 0,187 & 0,188 & 0,189 & $<0,001$ & 0,247 & 0,244 \\
\hline
\end{tabular}

a: Diferença estatística entre raças.

b: Diferença estatística entre níveis de concentrado na dieta.

c: Diferença estatística na interação entre raças e níveis de concentrado na dieta. 
As concentrações de proteína e energia no corpo vazio foram diferentes apenas entre raças, como já foi citado anteriormente. A concentração de proteína ( $\mathrm{g} / \mathrm{kg}$ de peso corporal vazio (PCVz)) foi mais elevada para a raça Nelore do que para a Brangus, talvez porque a média de PCVz do Nelore (321 kg) seja menor do que a do Brangus (344 kg).

FERREIRA et al. (1998a), trabalhando com bovinos F1 Simental X Nelore não-castrados, VÉRAS et al. (2000) com animais Nelore, nãocastrados, e FONTES (1995), em compilação de vários experimentos observaram aumento nas concentrações de gordura e energia e diminuição na concentração de proteína com a elevação do PJ. Estas alterações são devido à desaceleração do crescimento muscular, segundo GRANT e HELFERICH (1991), que pode ser constatada pelo menor ganho de proteína por kg de ganho de peso corporal vazio (GPVz) (Gráfico 8) e aumento na deposição de gordura e do ganho de gordura por kg de GPVz, à medida que o peso corporal aumenta (Gráfico 9).

A concentração de energia (Mcal/kg de GPVz) foi maior para os animais Brangus quando comparados aos das raça Nelore. Os valores de energia e proteína para cada raça, de acordo com o nível de concentrado estão demonstrados a seguir, nos Gráficos 6 e 7.

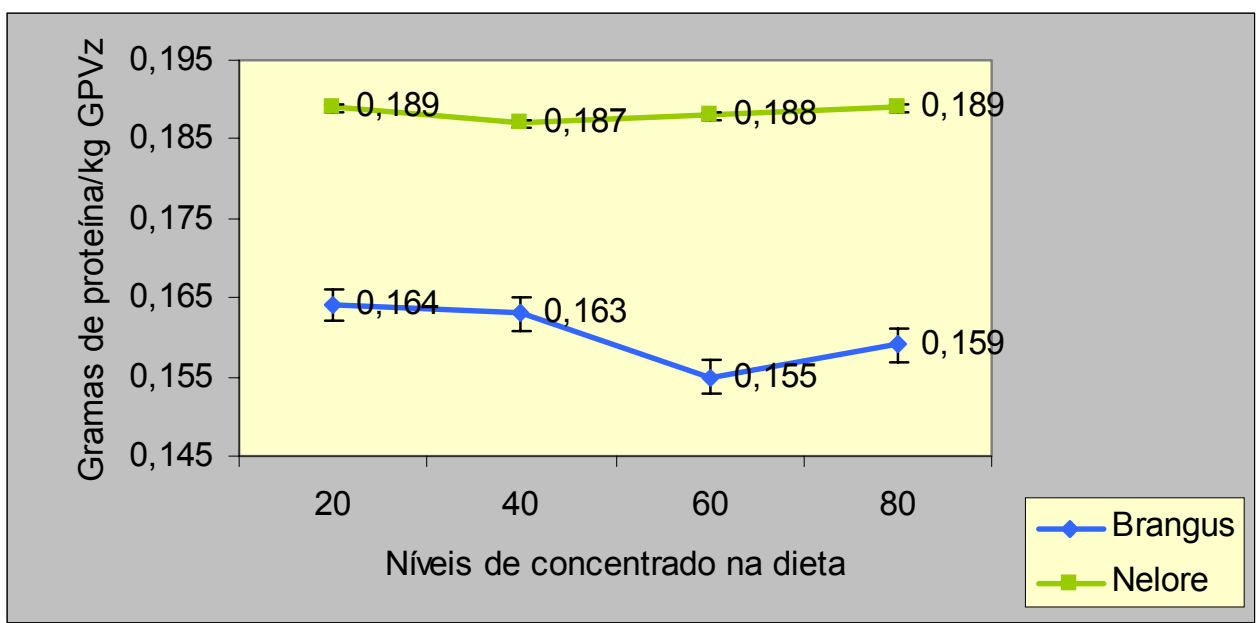

Gráfico 6. Concentração de proteína em gramas por kg de GPVz em função dos níveis de concentrado na dieta.

ALMEIDA et al. (2001) trabalharam com animais mestiços Holandês $X$ Gir alimentados com $26 \%$ de concentrado. O conteúdo de proteína aumentou com a elevação do PCVz, entretanto a concentração em g/kg de 
PCVz diminuiu de 212,58 em animais com $116 \mathrm{~kg}$ para 196,64 em animais de $399 \mathrm{~kg}$ de PCVz. Resultados diferentes foram encontrados neste trabalho para os animais ingerindo $20 \%$ de concentrado na dieta. O conteúdo de proteína aumentou, entretanto, a concentração deste nutriente em $\mathrm{g} / \mathrm{kg}$ de PCVz manteve-se semelhante no início e final do experimento, para a raça Brangus ambas raças (Brangus: $164 \mathrm{~g} / \mathrm{kg}$ de PCVz e Nelore: $189 \mathrm{~g} / \mathrm{kg}$ de PCVz).

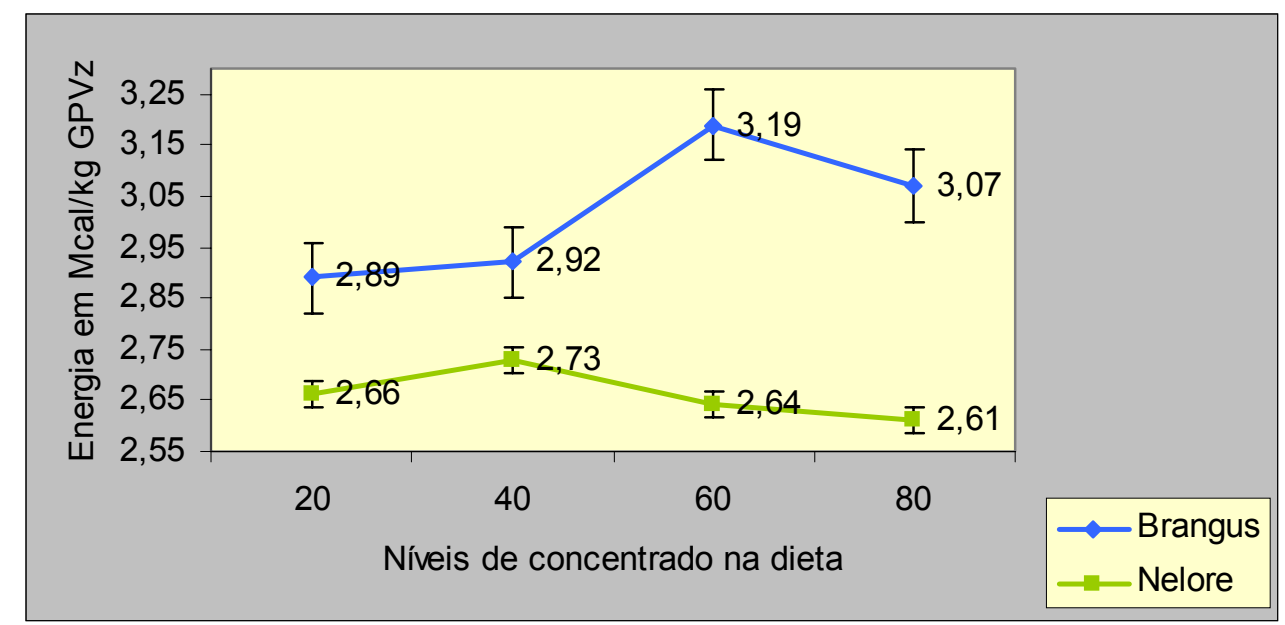

Gráfico 7. Concentração de energia em Mcal por kg de GPVz em função dos níveis de concentrado na dieta.

VÉRAS et al. (2001) trabalharam com animais inteiros, Nelore e F1 Simental X Nelore alimentados com $25 ; 37,5 ; 50 ; 62,5$ e $75 \%$ de concentrado na dieta. As concentrações de proteína em $\mathrm{g} / \mathrm{kg}$ de peso corporal vazio e energia em MCal/kg foram de 184,87 e 2,31; 186,74 e 2,34; 186,52 e 2,42; 184,60 e 2,45; 185,97 e 2,42; 186,49 e 2,46, respectivamente para cada um dos tratamentos, para animais de $400 \mathrm{~kg}$ de peso vivo em jejum (PJ) ou $346,35 \mathrm{~kg} \mathrm{PCV}$. Os valores de proteína foram semelhantes aos obtidos com os animais da raça Nelore deste experimento e superiores aos dos Brangus. Os valores de energia foram mais baixos do que os obtidos com os animais Nelore e os Brangus. 


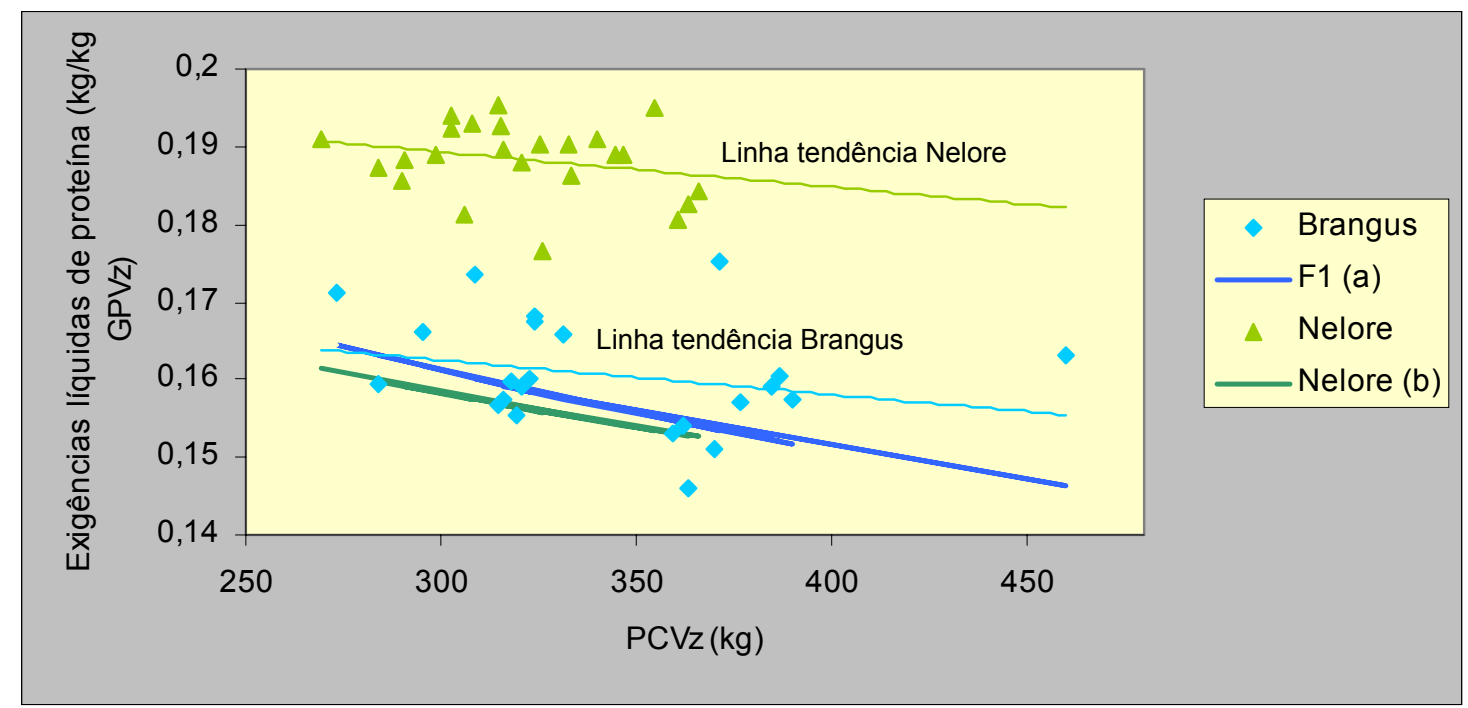

Gráfico 8. Exigências líquidas de proteína (kg) por kg de GPVz, em função do PCVz (kg).

a: Valores estimados a partir da equação de FONTES (1995) para animais F1 Angus $X$ Nelore $\left(Y=0,58819 X^{-0,22697} ; R^{2}=0,95\right)$.

b: Valores estimados a partir da equação de FONTES (1995) para animais Nelore $\left(Y=0,4526 X^{-0,18414} ; R^{2}=0,92\right)$.

As exigências de proteína líquida foram diferentes apenas entre raças, cujas médias foram de 0,160 kg e 0,188 $\mathrm{kg}$ por $\mathrm{kg}$ de ganho de peso vazio para as raças Brangus e Nelore, respectivamente.

Observando os dados do gráfico, é possível notar que as exigências líquidas de proteína são semelhantes entre animais F1 Angus X Nelore, citados por FONTES (1995), e os Brangus deste experimento. Entretanto o mesmo autor encontrou valores mais baixos para animais da raça Nelore em comparação aos Nelore deste experimento. Esta diferença de valores pode ter ocorrido porque os animais utilizados por FONTES (1995) foram abatidos quando os animais atingiam 90, 100 ou $110 \%$ do peso à maturidade das fêmeas do seu grupo racial, ou seja, eram animais de maior peso vivo quando comparados aos que foram utilizados neste trabalho (peso médio de $361,90 \mathrm{~kg}$ ). E, como já foi citado, animais de maior peso corporal tendem a apresentar menores exigências de proteína, já que há desaceleração do crescimento muscular. Os valores obtidos por FONTES (1995) aproximamse das estimativas segundo o ARC (1980), para animais não-castrados de porte médio. 
As exigências líquidas de proteína de animais Holandês X Gir, de acordo com ALMEIDA et al. (2001), foram de 187,4 g para um animal de 304 $\mathrm{kg}$ de PCVz. Estes valores estão próximos dos obtidos com os animais da raça Nelore, porém acima da raça Brangus.

No Gráfico 9, os resultados de FONTES (1995) indicam semelhança, novamente, entre animais F1 Angus X Nelore e Brangus para o ganho de gordura. Para a raça Nelore, os dados do autor são mais elevados, justificados também pelo abate com maior peso vivo, e provavelmente, maior maturidade fisiológica dos animais (com conseqüente maior deposição de gordura). É importante observar que de acordo com as equações de FONTES (1995), o ganho de gordura dos animais da raça Nelore é superior ao dos F1, resultado semelhante aos de GONÇALVES (1991b) e TEIXEIRA (1987).

FERREIRA et al. (1998a), observaram que o conteúdo de gordura no PCVz e no GPVz em animais F1 Simental X Nelore elevou-se até o nível de $50 \%$ de concentrado na ração, a partir do qual os valores tornaram-se relativamente constantes até $75 \%$.

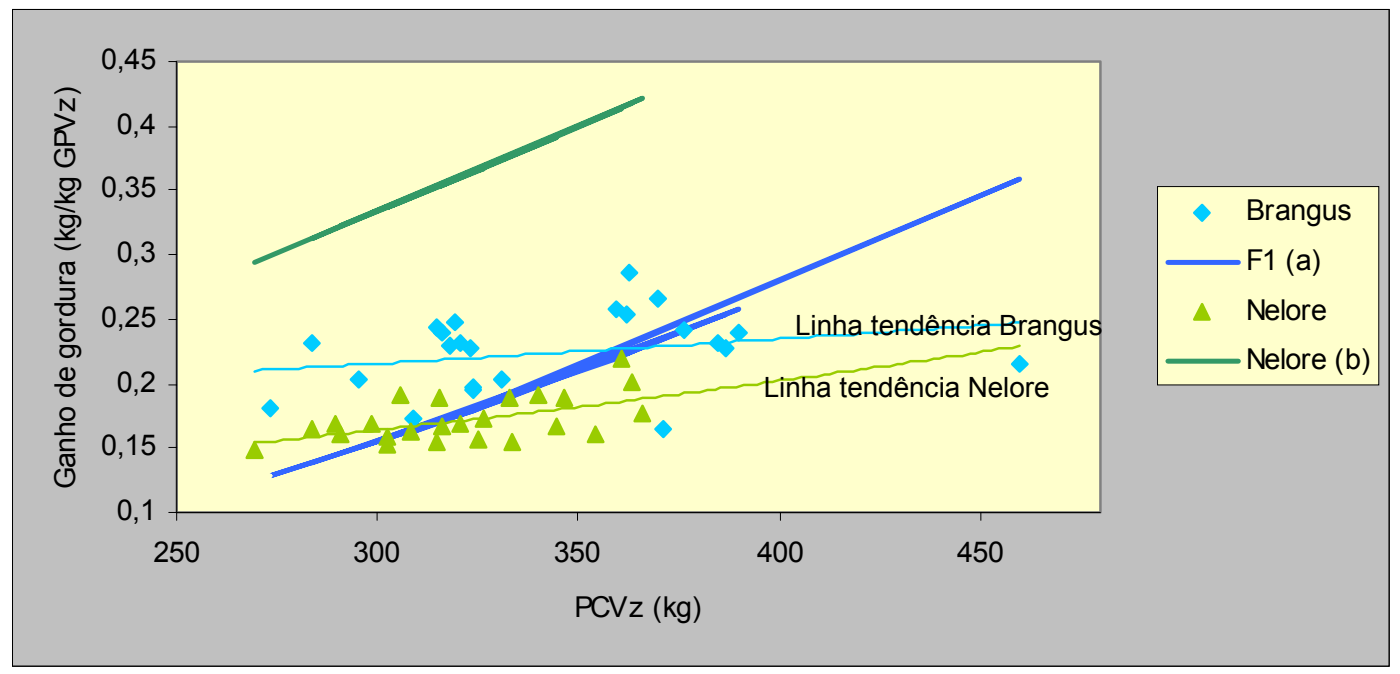

Gráfico 9. Ganho de gordura (kg) por kg de GPVz, em função do PCVz (kg).

a: Valores estimados a partir da equação de FONTES (1995) para animais $F 1$ Angus $X$ Nelore $\left(Y=0,000002 X^{1,97304} ; R^{2}=0,95\right)$

b: Valores estimados a partir da equação de FONTES (1995) para animais Nelore $\left(Y=0,000430 X^{1,16657} ; R^{2}=0,96\right)$ 


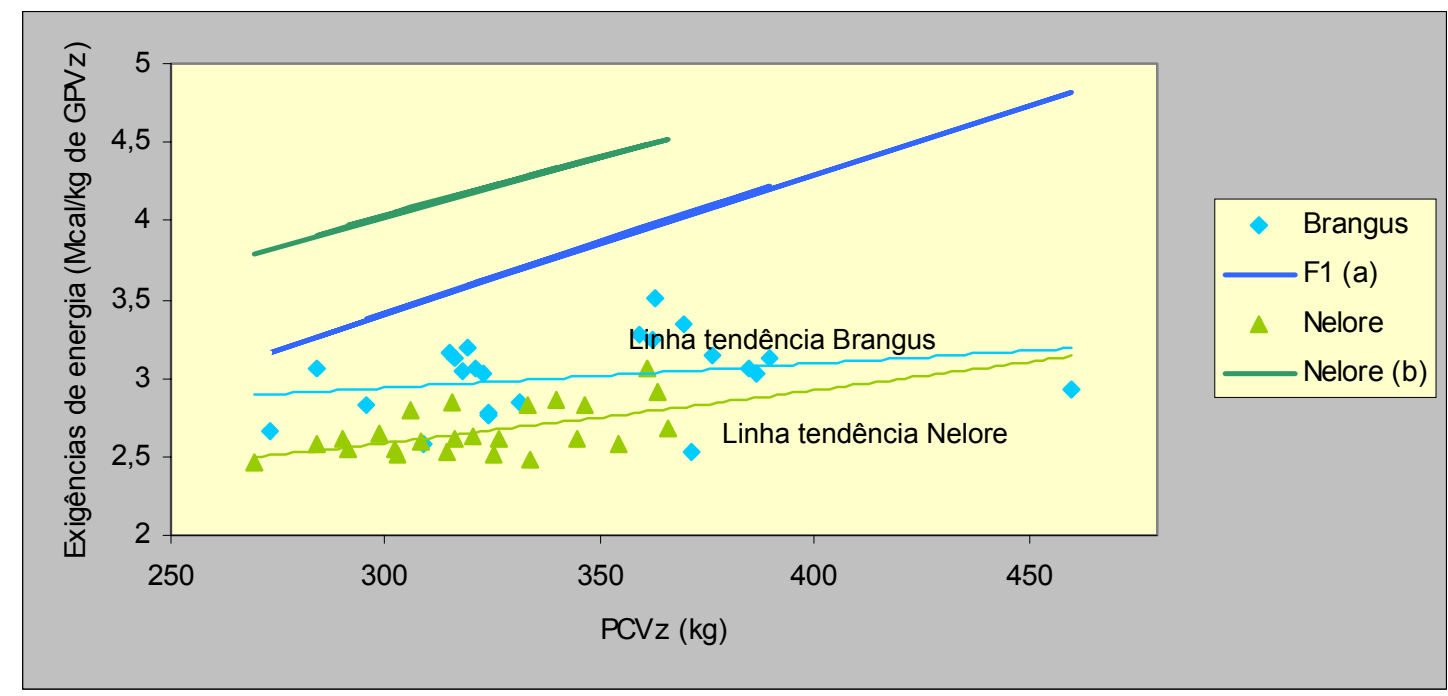

Gráfico 10. Exigências líquidas de energia (Mcal) por kg de GPVz em função do PCVz (kg).

a: Valores estimados a partir da equação de FONTES (1995) para animais mestiços Angus $X$ Nelore $\left(Y=0,1573 X^{-0,54147} ; R^{2}=0,93\right)$

b: Valores estimados a partir da equação de FONTES (1995) para animais Nelore $\left(Y=0,15818 X^{0,56787} ; R^{2}=0,96\right)$

As exigências de energia líquida para ganho de peso foram diferentes apenas entre raças, com médias de 3,02 e 2,66 Mcal por kg de ganho de peso vazio, respectivamente para os animais Brangus e Nelore. De acordo com estes valores é possível notar que a raça Brangus tem maior deposição de gordura do que a Nelore.

As exigências de energia tanto para os animais $F 1$ quanto para 0 Nelore de acordo com FONTES (1995) foram superiores às estimadas neste experimento. Provavelmente, esta diferença de valores tenha ocorrido devido à idade jovem dos animais, que não alcançaram a fase de deposição de gordura na curva de crescimento fisiológico. Isto também impede que sejam observadas diferenças entre os níveis de concentrado na dieta sobre a deposição de energia.

No trabalho de ALMEIDA et al. (2001), as exigências líquidas de energia por kg de GPVz de animais Holandês X Gir foi de 3,46 Mcal para animais de $304 \mathrm{~kg}$ de PCVz. Estes valores estão acima dos encontrados para a raça Nelore e próximos aos dos Brangus (animais mestiços europeu X zebu). 
BULLE et al. (2002b) não encontraram efeito de raça (paterna, britânica ou continental, em tourinhos mestiços europeu $X$ zebu) ou tratamento $(79,85$ ou $91 \%$ de concentrado na dieta) na composição do ganho de peso vazio. Os animais britânicos apresentaram teores de $28,9 \%$ de gordura e 3,67 Mcal $/ \mathrm{kg}$ de GPVz, valores acima dos encontrados para os Brangus deste experimento (22,86\% de gordura e 2,99 Mcal).

Trabalhando com tourinhos Santa Gertrudis, BERNDT et al. (1999) observaram 42\% de lipídios no GPVz para animais de $407 \mathrm{~kg}$. Estes animais foram suplementados no período pré-desmama e passaram por um longo período de confinamento, o que pode ter influenciado esta elevada proporção.

A composição corporal de animais Nelore, Nelore $X$ Marchigiana e mestiços leiteiros com sangue Holandês foi estimada por LANNA et al. (1997b). Os teores de lipídios finais foram de 19, 16 e 18\% no corpo vazio, respectivamente. Os autores justificam os baixos teores de gordura como função dos animais serem machos inteiros, e estarem em crescimento compensatório, apesar de terem sido abatidos com peso elevado (cerca de $500 \mathrm{~kg}$ ).

JORGE et al. (1999) ofereceram alimentação ad libitum e restrita (níveis de proteína e energia $15 \%$ acima da mantença) com $50 \%$ de concentrado para tourinhos Gir, Guzerá, Tabapuã mocho e Nelore. Não foram encontradas diferenças entre as raças para as concentrações corporais de proteína, gordura e energia. Assim como observado em outros trabalhos já citados, os animais abatidos com maiores pesos corporais apresentaram menores porcentagens de proteína e maiores de gordura.

FERREL e JENKINS (1998) forneceram alimento ad libitum ou restrito com $34 \%$ de concentrado a novilhos de diferentes combinações de raças paternas e maternas. Os animais que receberam ração ad libitum foram mais pesados no momento de abate e apresentaram maiores quantidades de água, gordura, proteína, cinzas e energia do que os alimentados com restrição. As taxas de ganho dos componentes do corpo também foram maiores $(P<0,01)$ para os animais que tinham alimento à vontade. 
TEDESCHI et al. (2002) trabalharam com animais Nelore, inteiros e castrados, recebendo $40 \%$ de concentrado na dieta, alimentados ad libitum ou com $65 \%$ do consumo ad libitum. Para os animais inteiros, não foi encontrada diferença entre tratamentos para a porcentagem de água (61,9 e $63,2 \%$ ) e proteína (18,5 e 18,6\%) no PCVz, respectivamente. Para a gordura $(56,5$ e $48,9 \%)$ e proteína (17,5 e 18,3\%) no GPVz também não foram encontradas diferenças para animais alimentados ad libitum ou com restrição. Os valores de proteína são semelhantes aos obtidos neste trabalho, com tourinhos Nelore. Porém os animais eram de peso menor ao abate do que os animais alimentados ad libitum utilizados por TEDESCHI et al. (2002), que apresentavam média de $383 \mathrm{~kg}$ de PVJ no abate.

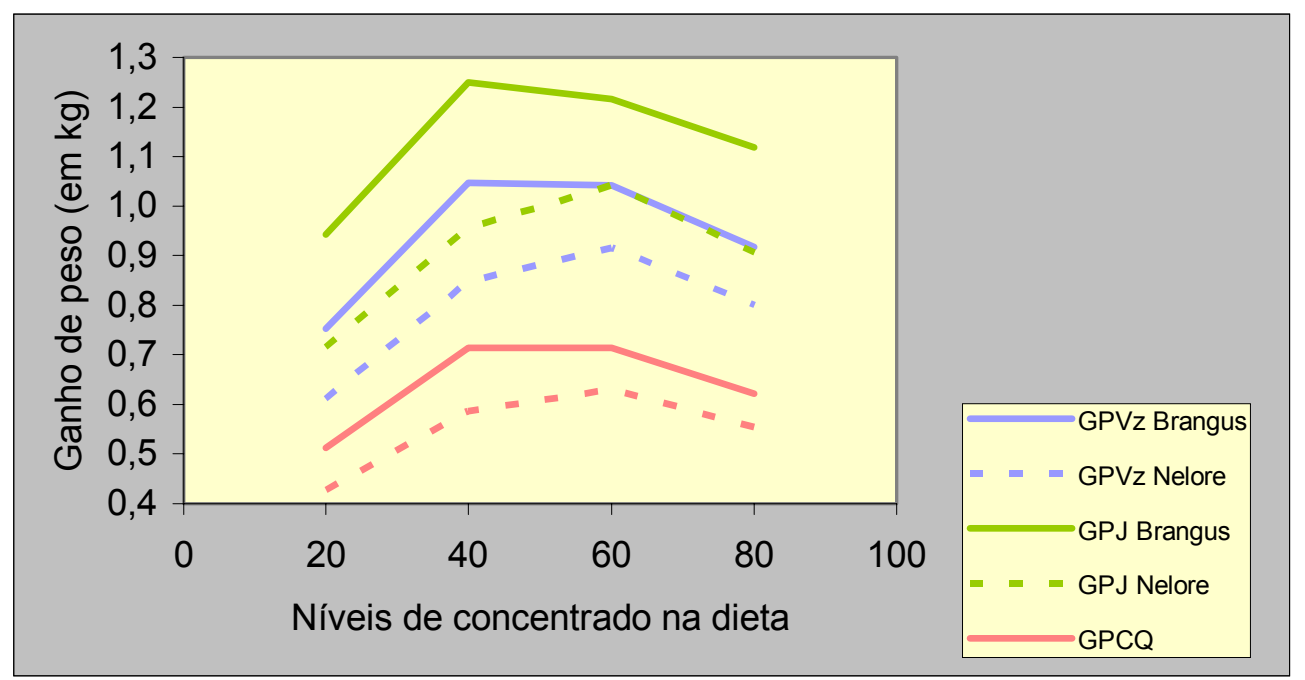

Gráfico 11. Ganho de peso em jejum (GPJ), ganho de peso vazio (GPVz), ganho de peso de carcaça quente (GPCQ) dos animais das raças Brangus e Nelore em função dos níveis de concentrado na dieta. 


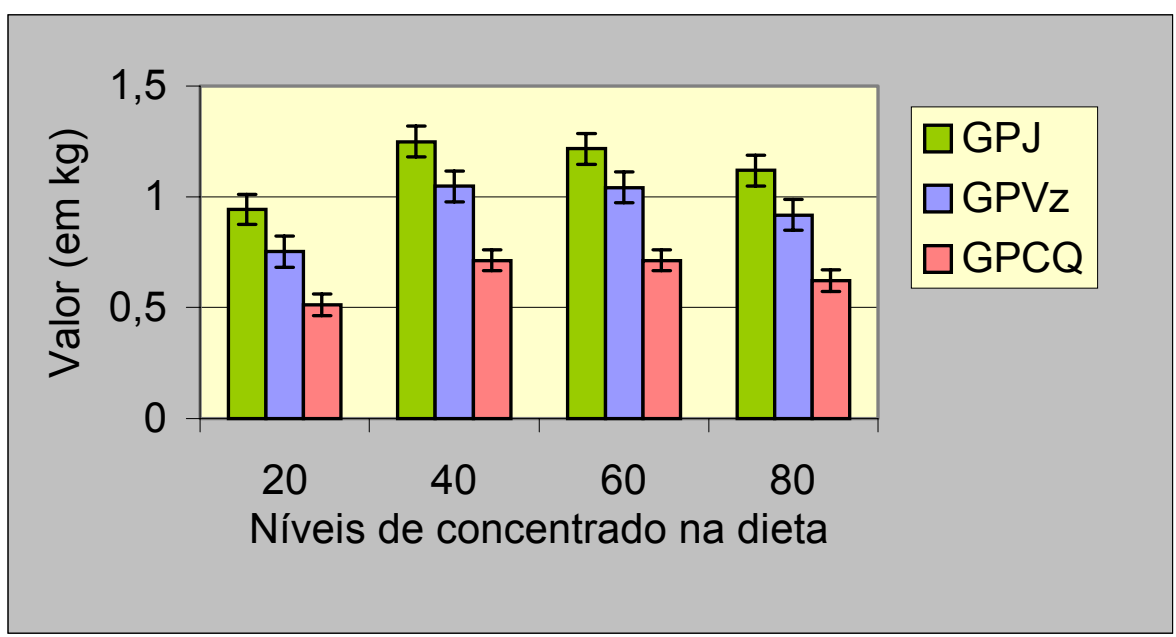

Gráfico 12. Relações entre o GPJ (ganho de peso em jejum), GPVz (ganho de peso vazio) e GPCQ (ganho de peso de carcaça quente) de tourinhos da raça Brangus alimentados com diferentes proporções de concentrado na dieta.

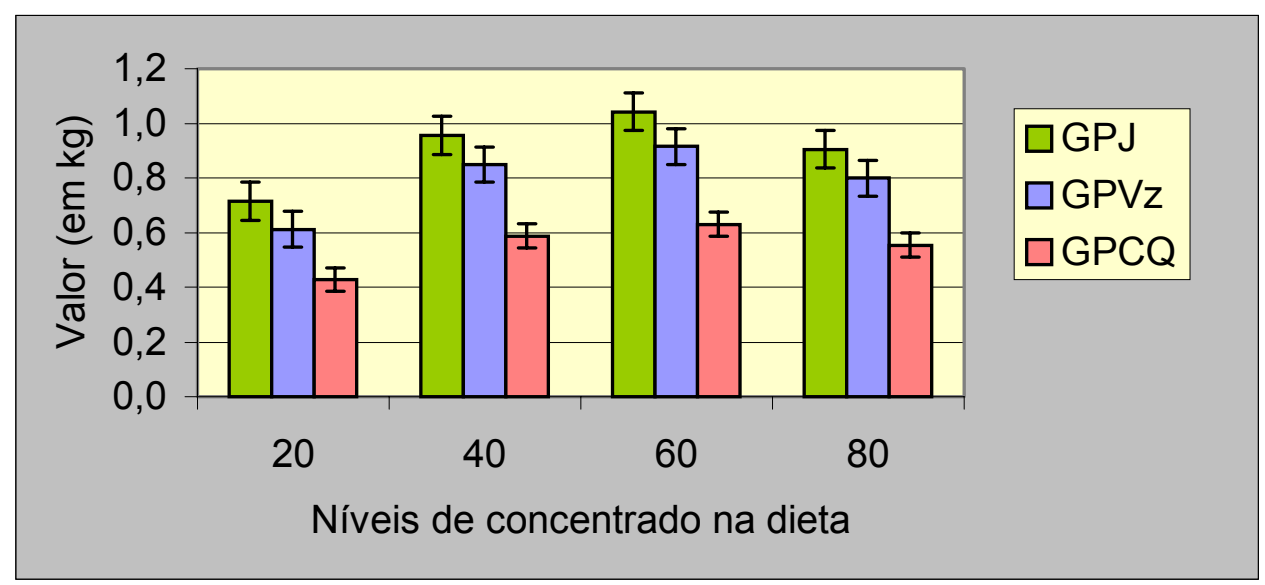

Gráfico 13. Relações entre o GPJ, GPVz e GPCQ de tourinhos da raça Nelore alimentados com diferentes proporções de concentrado na dieta.

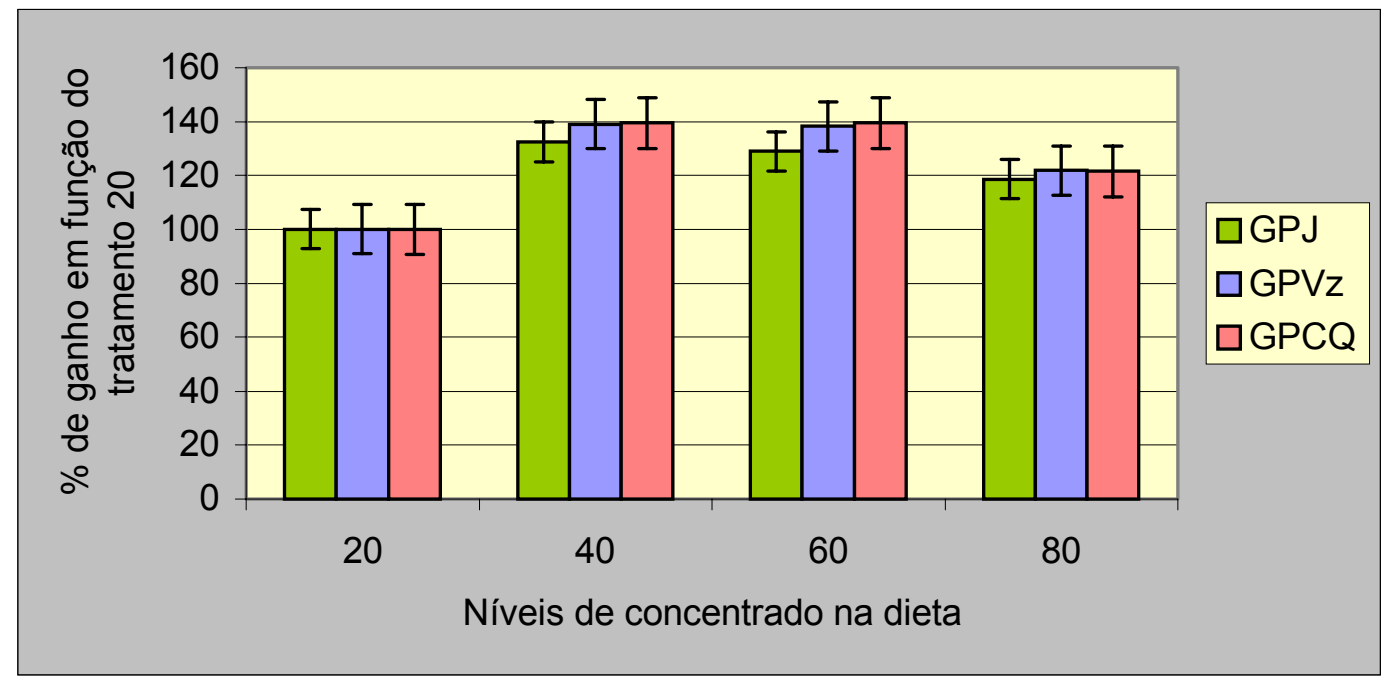

Gráfico 14. GPJ, GPVz e GPCQ em relação ao tratamento de $20 \%$ de concentrado na dieta para animais da raça Brangus. 


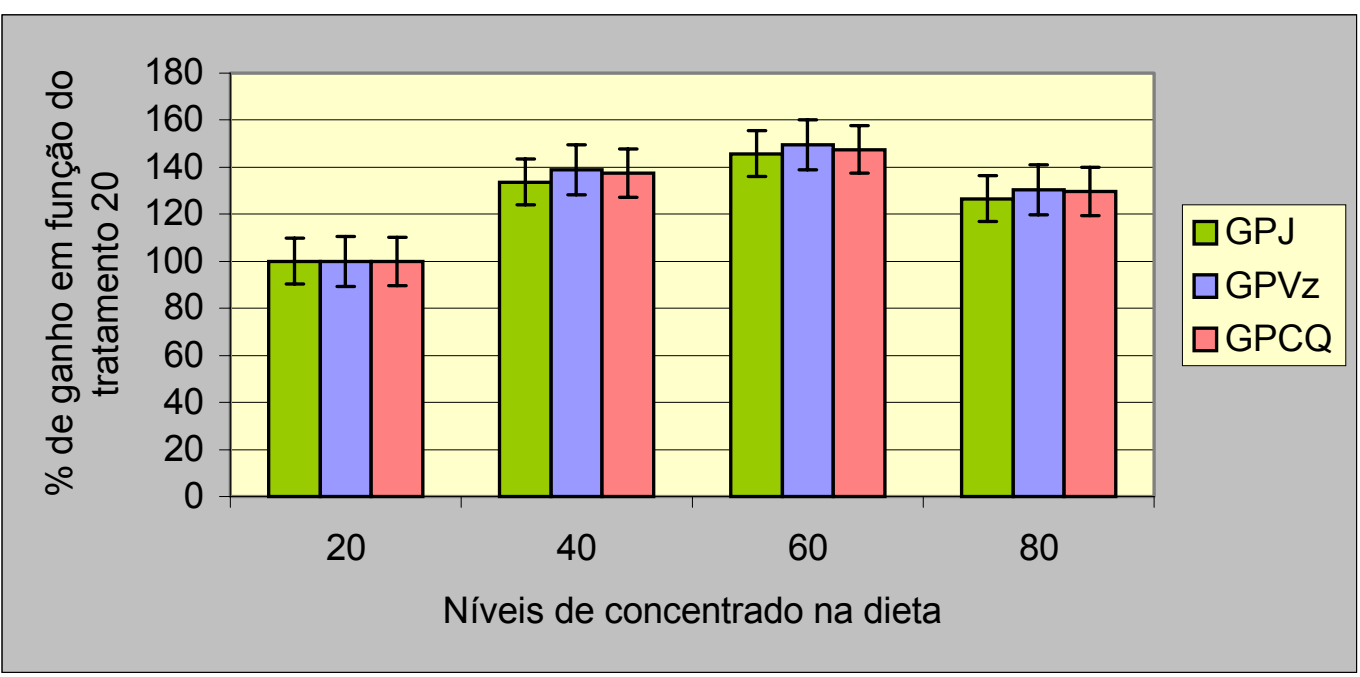

Gráfico 15. GPJ, GPVz e GPCQ em relação ao tratamento de $20 \%$ de concentrado na dieta para animais da raça Nelore.

No Gráfico 14, é possível notar que para a raça Brangus, os maiores ganhos de peso em jejum e vazio ocorreram quando foi fornecida a dieta com $40 \%$ de concentrado, entretanto, os maiores ganhos de carcaça quente foram para os animais que receberam $60 \%$ de concentrado na dieta. Os ganhos foram cerca de $40 \%$ maiores que o tratamento com $20 \%$ de concentrado.

Para os animais da raça Nelore (Gráfico 15), os melhores ganhos de peso em jejum, vazio e de carcaça quente foram para os animais alimentados com $60 \%$ de concentrado, alcançando cerca de $45 \%$ a mais de ganho quando comparados ao tratamento com $20 \%$ de concentrado.

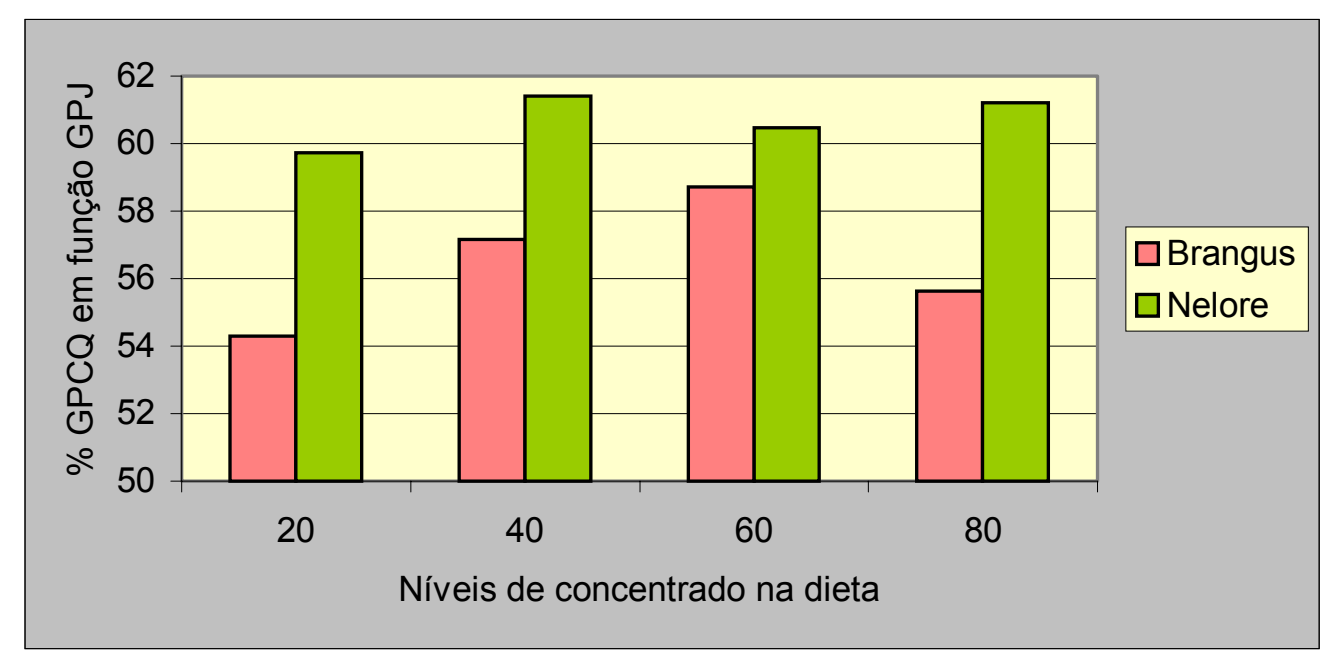

Gráfico 16. GPCQ em porcentagem do GPJ nos diferentes tratamentos para animais das raças Brangus e Nelore. 
No Gráfico 16 estão descritos os GPCQ em função do GPJ, e é possível notar que os animais da raça Nelore apresentaram maior rendimento de carcaça em relação ao Brangus. Para o Brangus o melhor rendimento foi obtido com $60 \%$ de concentrado na dieta. Para a raça Nelore, os rendimentos das dietas com 40 e $80 \%$ de concentrados foram os maiores, com valores muito semelhantes entre eles. LEME et al. (2000), fornecendo 20 ou $80 \%$ de concentrado na dieta, com milho ou polpa cítrica para tourinhos Santa Gertrudis, observaram que o maior GPCQ em \% do GPJ foi para o tratamento com $80 \%$ de concentrado à base de milho.

Tabela 8. Equações de regressão dos parâmetros de composição corporal para as raças Brangus e Nelore em função do nível de concentrado na dieta.

\begin{tabular}{|c|c|c|}
\hline Item & Equação de regressão $^{a}$ & $R^{2^{b}}$ \\
\hline Peso vivo jejum final (kg) & $Y=-0,0431 X^{2}+4,6543 X+278,64$ & 0,9993 \\
\hline Peso vazio final (kg) & $Y=-0,0415 X^{2}+4,4898 X+232,57$ & 0,9995 \\
\hline Ganho peso vazio (kg/dia) & $Y=-0,0002 X^{2}+0,0269 X+0,2445$ & 0,9930 \\
\hline caça quente final $(\mathrm{kg})$ & $Y=-0,0282 X^{2}+3,0453 X+148,99$ & 0,9995 \\
\hline (kg/dia) & $Y=-0,0002 X^{2}+0,0184 X+0,1697$ & 0,9940 \\
\hline \multicolumn{3}{|c|}{ Composição química } \\
\hline Ágı & $Y=-0,0218 X^{2}$ & 0,9784 \\
\hline kg) & $Y=-0,0$ & 0,9634 \\
\hline Prot & $Y=-0,0063 X$ & 0,9790 \\
\hline Cinz & $Y=-0,0015 X^{2}+$ & 0,9787 \\
\hline al) & $Y=-0,1443 X^{2}$ & 0,9855 \\
\hline \multicolumn{3}{|c|}{ Taxas de deposição } \\
\hline & $Y=-0,0001 X^{2}$ & 0,9793 \\
\hline o (kg/dia) & $Y=-0,5469 X^{2}+0$ & 0,9953 \\
\hline & $Y=-0,2014 X^{2}+0,1$ & 0,9971 \\
\hline & $Y=-0,0975 X^{2}+0,1$ & 0,9828 \\
\hline Mcal/dia & $Y=-0,0007 X^{2}+0,0825 X+0,5613$ & 0,9998 \\
\hline
\end{tabular}

a: Os valores de $X$ (níveis de concentrado) para as equações de regressão estão em porcentagem (20, 4060 ou 80), exceto para as equações do extrato etéreo, proteína e cinzas depositados, onde foram utilizados números decimais $(0,20$; 0,$40 ; 0,60$ ou 0,80 ) a fim de elevar os valores dos coeficientes de X.

b: Coeficiente de correlação. 
Tabela 9. Correlação entre a composição do corpo vazio (CVz) e a composição do ganho de peso vazio (GPVz).

\begin{tabular}{|c|c|c|c|c|c|c|c|c|c|c|c|c|}
\hline & $A C V z$ & $E E C V z$ & $P C V z$ & $C C V z$ & $E C V z$ & $G P V z$ & $A G P V z$ & $E E G P V z$ & $P G P V z$ & CGPVz & $E L$ & $P L$ \\
\hline PCVz & & & - & $1,000^{*}$ & $-0,774^{*}$ & $-0,210$ & $0,888^{*}$ & $-0,888^{*}$ & $0,886^{*}$ & $0,883^{*}$ & $-0,774^{*}$ & $0,999^{*}$ \\
\hline ECVz & & & & & - & 0,254 & $-0,978^{*}$ & $0,978^{*}$ & $-0,979^{*}$ & $-0,980^{*}$ & $1,000^{*}$ & $-0,760^{*}$ \\
\hline GPVz & & & & & & - & - 0248 & 0,253 & $-0,262$ & - 0,272 & 0,254 & - 0,192 \\
\hline AGPVz & & & & & & & - & $-1,000^{*}$ & $0,999^{*}$ & $0,998^{*}$ & $-0,978^{*}$ & $0,877^{*}$ \\
\hline EEGPVz & & & & & & & & 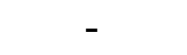 & $-0,999^{*}$ & $-0,999^{*}$ & $0,978^{*}$ & $-0,877^{*}$ \\
\hline CGPVz & & & & & & & & & & - & $-0,980^{*}$ & $0,871^{*}$ \\
\hline & & & & & & & & & & & - & $-0,760^{*}$ \\
\hline PL & & & & & & & & & & & & - \\
\hline
\end{tabular}

* Indica correlação significativa $(\mathrm{P}<0,01)$.

ACVz: água no corpo vazio (\%).

EECVz: extrato etéreo no corpo vazio (\%).

PCVz: proteína no corpo vazio (\%).

CCVz: cinza no corpo vazio (\%).

ECVz: energia no corpo vazio (Mcal $/ \mathrm{kg})$.

GPVz: ganho de peso vazio ( $\mathrm{kg} / \mathrm{dia})$.

AGPVz: porcentagem de água no GPVz.

EEGPVz: porcentagem de extrato etéreo no GPVz.

PGPVz: porcentagem de proteína no GPVz.

CGPVz: porcentagem de cinzas no GPVz.

$\mathrm{EL}$ : energia líquida em Mcal/kg de GPVz.

$P L:$ proteína líquida em $\mathrm{kg} / \mathrm{kg}$ de $\mathrm{GPV}$. 
As quantidades de água, proteína e cinzas no $\mathrm{CVz}$ estão inversamente correlacionadas com a energia no CVZ, enquanto que o extrato etéreo está diretamente correlacionado.

A porcentagem de água no $\mathrm{CVz}$ está altamente correlacionada com a proteína líquida, e apresenta correlação positiva com as porcentagens de água, proteína e cinzas no GPVz. As correlações com o extrato etéreo e energia líquida são negativas.

A porcentagem de extrato etéreo no corpo vazio apresentou correlações positivas com o extrato etéreo e energia líquida do GPVz, e correlação negativa com a água, proteína, cinzas e proteína líquida do GPVz.

Assim, é possível que sejam utilizadas as medidas de água e extrato etéreo do CVz para a estimativa da composição do ganho de peso, o que torna os estudos sobre composição corporal mais baratos e práticos.

Os animais utilizados neste trabalho foram abatidos em idade jovem, o que provavelmente resultou em valores elevados de proteína e baixos de gordura e energia no ganho de peso vazio quando comparados a outros trabalhos de composição corporal.

Entretanto, foi possível notar que a raça Brangus apresentou maiores exigências de energia e maior deposição de gordura no ganho em relação ao Nelore, que por sua vez teve maiores exigências de proteína. Este tipo de resposta pode ter ocorrido porque os animais da raça Brangus depositam mais gordura do que o Nelore, e/ou porque são animais mais precoces, que iniciaram a deposição de gordura antes do Nelore.

É importante que sejam executados novos trabalhos de pesquisa que avaliem a composição corporal de animais das raças Brangus e Nelore, porém abatidos em idade mais avançada do que a utilizada neste experimento (14 meses). 


\section{Conclusões}

$\checkmark$ Os ganhos médios diários de peso vivo em jejum, de peso vazio e de peso de carcaça quente foram diferentes entre as raças com as maiores médias para a raça Brangus. Os ganhos de peso vazio e de carcaça quente também apresentaram diferenças entre os níveis de concentrado na dieta; a dieta com $40 \%$ de concentrado resultou em maiores ganhos para a raça Brangus e a de $60 \%$ de concentrado para a raça Nelore.

$\checkmark$ A digestibilidade das dietas foi diferente entre raças para a proteína bruta, matéria mineral e nutrientes digestíveis totais. Entre níveis de concentrado na dieta houve diferença para os coeficientes de digestibilidade da fibra bruta e fibra em detergente neutro, nutrientes digestíveis totais, energia digestível e metabolizável.

$\checkmark$ As composições do corpo vazio e do ganho de peso vazio foram diferentes apenas entre raças. A raça Brangus apresentou as maiores médias de extrato etéreo e energia e a Nelore as maiores médias de água, proteína e cinzas.

$\checkmark$ As exigências líquidas de proteína e de energia para o ganho de peso vazio foram diferentes entre raças. A raça Nelore apresentou as maiores exigências de proteína, e a Brangus as de energia. De acordo com estes resultados, é possível observar que os animais da raça Brangus apresentam maior deposição de gordura do que o Nelore.

Não foram observadas diferenças entre os níveis de concentrado na dieta para a composição corporal, provavelmente devido à idade jovem dos 
animais que não alcançaram a fase de maior deposição de gordura na curva de crescimento. 


\section{Referências bibliográficas}

AGRICULTURAL RESEARCH COUNCIL - ARC. The nutrient requirements of ruminants livestock. London: Commonwealth Agricultural Bureaux, 351 p., 1980.

ALLEONI, G. F.; LEME, P. R.; BOIN, C.; et al. Determinação da composição do corpo vazio, do ganho de peso, e das exigências de energia e proteína para mantença e ganho de peso em bovinos da raça Nelore, Canchim e Brangus. - Relatório Científico: Processo Fapesp 97/02590-5*, abril - 2001.

ALLEONI, G. F.; LEME, P. R.; BOIN, C.; et al. Avaliação da composição química e física dos cortes da costela para estimar a composição química corporal de novilhos Nelore. - Rev. Bras. Zootec., v. 26, n. 2, p. 382-390, 1997.

ALMEIDA, M. I. V. ; FONTES, C. A. A. ; ALMEIDA, F. Q. ; et al. Conteúdo corporal e exigências líquidas de energia e proteína de novilhos mestiços Holandês-Gir em ganho compensatório. Rev. Bras. Zootec., v. 30, n. 1, p. 205-214, 2001.

ALVES, J. B. ; STAGLIANO, R. L. BASTOS, J. F. P. et al. Desempenho de novilhos zebuínos e mestiços em confinamento com diferentes alimentações. In: REUNIÃO ANUAL DA SOCIEDADE BRASILEIRA DE ZOOTECNIA, 35, 1998. Botucatu. Anais...Botucatu: SBZ, p. $311,1998$.

ANDERSON, P. T.; BERGEN, W. G.; MERKEL, R. A. et al. The Effects of dietary crude protein level on rate, efficiency and composition of gain of growing beef bulls. J. Anim. Sci., Champaign, III, v. 66, n. 8, p. 1990-1996, 1988a.

ANDERSON, P. T.; HAWKINS, D. R.; BERGEN, W. G. et al. A note on dry matter intake and composition of gain of simmental bulls and steers fed to some weight or age. Anim. Prod., Edimburgh, UK, v. 47, n. 3, p. 493-496, aug., 1988b.

ANDRADE, A. T. Digestão total e parcial da matéria seca, matéria orgânica, energia bruta e proteína bruta em diferentes grupos genéticos de bovídeos. Viçosa, MG: UFV, 181p. Dissertação (Doutorado em Zootecnia) Universidade Federal de Viçosa, 1992.

ANUALPEC 2001 Anuário da pecuária brasileira. Coord. by Nehmi, I. M. D. ; Nehmi Filho, V. A.; Ferraz, J. V. FNP Consultoria \& Comércio. Ed. Argos, São Paulo, SP, 359 p., 2001.

ARAÚJO, G. G. L.; COELHO da SILVA, J. F.; VALADARES FILHO, S. C. et al. Consumo e digestibilidade total dos nutrientes de dietas contendo diferentes níveis de volumoso, em bezerros. Rev. Bras. Zootec., v. 27, n. 2, p. 345-354, 1998.

ARAÚJO, G. G. L; COELHO da SILVA, J. F; VALADARES FILHO, S. C. et al. Consumo e digestibilidade total dos nutrientes de dietas contendo diferentes níveis de volumoso, em bezerros. In: REUNIÃO ANUAL DA SOCIEDADE BRASILEIRA DE ZOOTECNIA. 34, 1997. Juiz de Fora. Anais...Juiz de Fora: SBZ, p. 234, 1997. 
ARC. The Nutrient Requirements of Ruminant Livestock. Supplement $n^{\circ} 1$ Report of the protein Group of the ARC Working Party, Commonwealth Agricultural Bureau, Farnham Royal, UK, 1980.

BARBER, K. A.; WILSON, L. L.; ZIEGLER, J. H. et al. Charolais and Angus steers slaughtered at equal percentages of mature cow weight II. Empty body composition, energetic efficiency and comparison of compositionally similar body weights. J. Anim. Sci., Albany, NY, v. 53, n. 4, p. 898-906, oct., 1981.

BARBOSA, P F. Raças e estratégias de cruzamento para produção de novilhos precoces. In: I Simpósio de produção de gado de corte. Viçosa, 1999. Anais... Viçosa-MG. p.1-18. 1999.

BARTLE, S. J.; PRESTON, R. L.; MILLER, M. F. Dietary energy sources and density: effects of roughage equivalent, tallow level, and steers type on feedlot performance and carcass characteristics. J. Anim. Sci., v. 72, n. 8, p. 1943-1953, 1994.

BERCHIELLI, T. T. Efeito da relação volumoso:concentrado sobre a partição da digestão, a síntese de proteína microbiana, produção de ácidos graxos voláteis e o desempenho de novilhos em confinamento. Belo Horizonte: MG: UFMG, 1994. 104 p. Tese (Doutorado em Ciência Animal) - Universidade Federal de Minas Gerais, 1994.

BERG, R. T.; BUTTERFIELD, R. M. New concepts of cattle growth. New York: Sydney University. 240p. 1976.

BERNDT, A.; HENRIQUE, W.; LEME, P. R.; et al. Exigências de energia líquida para mantença e crescimento de tourinhos Santa Gertrudis em dietas de alto concentrado. In: REUNIẤO ANUAL DA SOCIEDADE BRASILEIRA DE ZOOTECNIA, Trabalho 0000, Viçosa, Julho, 2000 / (CD-Rom).

BERNDT, A.; LANNA, D. P. D.; LEME, P. R.; et al. Milho úmido, bagaço de cana e silagem de milho em dietas de alto concentrado. 2. Composição corporal e taxas de deposição dos tecidos. In: REUNIÃO ANUAL SOCIEDADE BRASILEIRA DE ZOOTECNIA, 36., 1999, Porto Alegre. Anais... Porto Alegre: Sociedade Brasileira de Zootecnia, p. 285, 1999.

BOIN, C. Alguns dados sobre exigências de energia e de proteína de zebuínos. In: Simpósio Internacional sobre Exigências Nutricionais de Ruminantes, Viçosa, Anais... Viçosa: UFV, 1995, p. 457-465, 1995.

BOIN, C.; LEME, P. R.; LANNA, D. P. D. et al. Tourinhos Nelore em crescimento e acabamento. 2. Exigências de energia líquida de mantença e eficiência de utilização da energia metabolizável para mantença e crescimento. In: REUNIÃO ANUAL DA SOCIEDADE BRASILEIRA DE ZOOTECNIA, 1994, Maringá, Anais... Maringá, p. 473, 1994.

BOIN, C.; MOURA, M. P. Comparação entre dois níveis de proteína bruta e e entre dois níveis de energia para zebuínos em crescimento. Boletim da Indústria Animal v. 34, n. 2, p. 155163, 1977.

BOUVIER, J. C.; VERMOREL, M. Utilisation énergétique et azotée d'une même ration par le mouton adulte à l'engraissement et l'agneau en croissance. Ann. Zootechnie v. 24 p. 697. 1975.

BRODERICK, A. G.; CLAYTON, M. K. A statistical evaluation of animal and nutrition factors influencing concentrations of milk urea nitrogen. Journal of Dairy Sci., v. 80, n. 11, p.29642971, 1997.

BULLE, M. L. M.; RIBEIRO, F. G.; LEME, P. R.; et al. Desempenho de tourinhos cruzados em dieta de alto teor de concentrado com bagaço de cana-de-açúcar como único volumoso. Rev. Bras. Zootec., v. 31, n. 1, p. 444-450, 2002a. 
BULLE, M. L. M.; RIBEIRO, F. G.; LEME, P. R.; et al. Exigências líquidas de energia e proteína de tourinhos de dois grupos genéticos alimentados com dietas de alto teor de concentrado. Rev. Bras. Zootec., v. 31, n. 1, p. 436-443, 2002b.

BURGER, P. J.; PEREIRA, J. C.; COELHO da SILVA, J. F. et al. Consumo e digestibilidade aparente total e parcial em bezerros holandeses alimentados com dietas contendo diferentes níveis de concentrado. Rev. Bras. Zootec., v. 29, n. 1, p. 206-214, 2000.

BURGER, P. J.; PEREIRA, J. C.; COELHO da SILVA, J. F.; et al. Consumo e digestibilidade em bezerros alimentados comdietas contendo níveis de concentrado. In: REUNIÃO ANUAL DA SOCIEDADE BRASILEIRA DE ZOOTECNIA, 35, Botucatu. Anais...Botucatu: SBZ, p. 599, 1998.

BYERS, F. M.; ROMPALA, R. E. Level of energy effects on patterns and energetic efficiency of tissue deposition in small or large mature size beef cattle. In: MOUNT, L. E. (Ed.) Symposium of energy metabolism, 8, Cambridge, 1980. Proceedings...Butterworths, London: EAAP Publ., n. 28, p. 141-146, 1980.

CARDOSO, R. C.; VALADARES FILHO, S. C.; COELHO da SILVA, J. F. et al. Consumo e digestibilidades aparentes totais e parciais de rações contendo diferente níveis de concentrado, em novilhos f1 Limousin X Nelore. Rev. Bras. Zootec. v. 29, n. 6, p. 1832$1843,2000$.

CARVALHO, A. U.; VALADARES FILHO, S. C.; COLEHO da SILVA, J. F.; et al. Níveis de concentrado em dietas de zebuínos. 1. Consumo e digestibilidade aparente. Rev. Bras. Zootec. v. 26; n. 5; p. 986-995, 1997.

CARVALHO, A. U.; VALADARES FILHO, S. C.; COELHO da SILVA, J. F. et al. Efeito de níveis de concentrado sobre o consumo e digestibilidade aparente em zebuínos. In: REUNIÃO ANUAL DA SOCIEDADE BRASILEIRA DE ZOOTECNIA, 33, 1996. Fortaleza. Anais...Fortaleza: SBZ, p. 61, 1996.

CATTON, J. S.; DHUYVETTER, D. V. Influence of energy supplementation on grazing ruminants: requirements and responses. J. Anim. Sci., v. 75, p. 533-542, 1997.

COELHO da SILVA, J. F.; LEÃO, M. I. Fundamentos de nutrição de ruminantes. Piracicaba, Livroceres, 380p. 1979.

DIAS, H. L. C. Consumo, digestibilidades aparentes totais e parciais de dietas contendo diferentes níveis de concentrado, em novilhos F1 LimousinXNelore. Viçosa, MG: UFV, 1999. 76p. Dissertação (Mestrado em Zootecnia) - Universidade Federal de Viçosa, 1999.

DOVE, $\mathrm{H}$. The ruminant, the rumen and the pasture resource: nutrient interactions in the grazing animal. In: HODGSON, J.; ILLUS, A. W. (Eds.) The ecology and management of grazing systems (eds.) CAB Internacional, p. 219-246, 1996.

DUKES, H. H Dukes Fisiologia dos Animais Domésticos. eds. SWENSON, M. J.; REECE, W. 11 ed. Rio de Janeiro, Guanabara Koogan. 856p. 1996.

EUCLIDES FILHO, K.; FIGUEIREDO, G. R.; EUCLIDES, V. P. B. Et al. Conversão alimentar e ganho de peso de animais Nelore F1 Simental-Nelore e Angus-Nelore. In: REUNIÃO ANUAL DA SOCIEDADE BRASILEIRA DE ZOOTECNIA, 33, 1996, Fortaleza. Anais...Fortaleza: SBZ, p. 67, 1996.

FAHEY JR., G. C.; BERGER, L. L. Carbohydrate nutrition of ruminants. In: $\mathrm{CHURCH,} \mathrm{D.} \mathrm{C.}$ (Ed.) The ruminant animal: digestive physiology and nutrition. New Jersey: Prentice Hall, p. 269-297, 1988. 
FEIJÓ, G. L. G.; SILVA, J. M.; THIAGO, L. R. L. Et al. Efeito de níveis de concentrado na engorda de bovinos confinados. Desempenho de novilhos F1 Pardo Suíço X Nelore. In: REUNIÃO ANUAL DA SOCIEDADE BRASILEIRA DE ZOOTECNIA, 33, 1996, Fortaleza. Anais...Fortaleza: SBZ, p. 70, 1996.

FELÍCIO, P. E de. Programa de novilho precoce da ACNB. In: Simpósio Bahia 2000, 1999, Salvador, BA, Anais..., p.15, 1999.

FERREIRA, M. A.; VALADARES FILHO, S. C.; COELHO da SILVA, J. F. et al. Consumo, conversão, ganho de peso e características da carcaça de bovinos F1 Simental-Nelore alimentados com diferentes níveis de concentrado nas rações. In: REUNIÃO ANUAL DA SOCIEDADE BRASILEIRA DE ZOOTECNIA, 34, 1997, Juiz de Fora. Anais... Juiz de Fora: SBZ, p. 280, 1997.

FERREIRA, M. de A., VALADARES FILHO, S. de C.; COELHO da SILVA, J. F.; et al. Composição corporal e exigências líquidas de proteína e energia para ganho de peso de bovinos F1 Simental X Nelore - Rev. Bras. Zootec., v. 28, n. 2, p. 352-360, 1998a.

FERREIRA, M. de A., VALADARES FILHO, S. de C.; COELHO da SILVA, J. F.; et al. Eficiência de utilização da energia metabolizável para ganho de peso e exigências de energia metabolizável e nutrientes digestíveis totais de bovinos F1 Simental X Nelore - Rev. Bras. Zootec., v. 28, n. 2, p. 368-373, 1998b.

FERREL, C. L.; JENKINS, T. G. Body composition and energy utilization by steers of diverse genotypes fed a high-concentrate diet during the finishing period: I Angus, Belgian Blue, Hereford, and Piedmontese Sires. J. Anim. Sci., v. 76, p. 637-646, 1998.

FONTES, C. A. A. Composição corporal, exigências líquidas de nutrientespara ganho de peso e desempenho produtivo de animais zebuínos e mestiços europeu-zebu. Resultados experimentais. In: Simpósio Internacional sobre Exigências Nutricionais de Ruminantes, 1995, Viçosa, Anais... Viçosa, UFV, 1995, p. 419-455, 1995.

FOX, D. G.; SNIFFEN, C. J.; O'CONNOR, J. D. et al. Search: agriculture. Ithaca, NY: Cornell University Agric. Exp. Sta., n. 34, 128p, 1992.

FREITAS, J. A. Composição corporal e exigência de energia e proteína de bovinos (zebuínos e mestiços) e bubalinos não castrados, em confinamento. Viçosa, MG: UFV, 1995. 132p. Tese (Mestrado em Zootecnia) - Universidade Federal de Viçosa, 1995.

FRISCH, S. E.; VERCOE, J. E. Food intake, eating rate, weight gains, metabolic rate and efficiency of feed utilization in Bos taurus and Bos indicus crossbred cattle. Anim. Prod., Edimburgh, UK, v. 25, n. 3, p. 343-358, dez., 1977.

GALVÃO, J. G.; FONTES, C. A. A.; PIRES, C. C. et al. Ganho de peso, consumo e conversão alimentar em bovinos não-castrados, de três grupos raciais, abatidos em diferentes estádios de maturidade (estudo I). Rev. Soc. Bras. Zootec., v. 20, n. 5, p. 494-501, 1991.

GARRET, W. N. Factor influencing energetic efficiency of beef production. J. Anim. Sci., Albany, NY, v. 51, n. 6 , p. $1434-1440,1980$.

GARRET, W. N.; MEYER, J. H.; LOFGREEN, J. P. The comparative energy requirements of sheep and cattle for maintenance and gain. J. Anim. Sci., v. 18, n. 2, p. 528-547, 1959.

GEAY, Y. Energy and protein utilization in growing cattle. J. Anim. Sci., v. 58, n. 3, p. 766-778, 1984. 
GESUALDY JR., A.; PAULINO, M. F.; VALADARES FILHO, S. C. et al. Níveis de concentrado na dieta de novilhos F1 Limousin X Nelore: desempenho reprodutivo. Rev. Bras. Zootec., v. 29, n. 5, p. 1458-1466, 2000.

GOMES, S. Z. Digestão parcial e total da proteína e energia e consumo voluntário de matéria seca por diferentes grupos genéticos de bovídeos. Viçosa. MG: UFV, 1982. 106p. Dissertação (Mestrado em Zootecnia) - Universidade Federal de Viçosa, 1982.

GONÇALVES, L. C.; COELHO da SILVA, J. F; ESTEVÃO, M. M.; TORRES, R. A. Consumo e digestibilidade da matéria seca e da energia em zebuínos e taurinos, seus mestiços e bubalinos. Rev. Soc. Bras. Zoot., Viçosa, MG, v. 20, n. 4, p. 385-395, 1991a.

GONÇALVES, L. C.; COELHO da SILVA, J. F.; CASTRO, A. C. G. et al.Exigências de proteína para novilhos de cinco grupos genéticos. Rev. Soc. Bras. Zoot., Viçosa, MG, v. 20, n. 5, p. 430-437, set/out., 1991b.

GRANT, A. L.; HELFERICH, W. G. An overview of growth. In: PEARSON, A. M.; DUTSON, T. R. (Ed). Growth regulation in farm animals. London: Elsevier Applied Science. p. 1-15, 1991.

HAMMOND, A. C.; KUNKLE, W. E.; BATES, D. B.; SOLLENBERGER, L. Use of blood urea nitrogen concentration to predict response to protein or energy supplementation in grazing cattle. In: PROCCEDINGS OF XVII INTERNATIONAL GRASSLAND CONGRESS, New Zealand Grassland Association, p. 189, 1993.

HANKINS, O. G.; HOWE, P. E. Estimation of the composition of beef carcasses and cuts. Washington, USDA, 1946. (Tech. Bulletin 926).

HENRIQUE, W.; LEME, P. R.; LANNA D. P. D.; et al. Equações para estimativa da composição química corporal de tourinhos Santa Gertrudis a partir do corte das 9-10-11 ${ }^{a}$ costelas. In: REUNIÃO ANUAL DA SOCIEDADE BRASIELIRA DE ZOOTECNIA, 36, 1999. Anais..., Porto Alegre, p. 352, 1999.

HOOG, B. W. Compensatory growth in ruminants. In: PEARSON, A. M.; DUTSON, T. R. (Ed). Growth regulation in farm animals. London: Elsevier Applied Science. p. 103-134, 1991.

HORROCKS, D.; PHILLIPS, G. D. Factors affecting the water and food intakes of European and zebu-type cattle. J. Agric. Sci., London, v. 56, n. 3, p. 379-381, Jun., 1961.

HUNTER, R. A.; SIEBERT, B. D. Utilization of low-quality roughage by Bos taurus and Bos indicus cattle. 1- Rumen digestion. Br. J. Nutr., cambridge, v. 53, n. 3, p. 637-648, 1985.

JONES, S. D. M.; ROMPALA, R.E.; JEREMIAH, L. E. Growth and composition of the empty body in steers of different maturity types fed concentrate or forage diets. J. Anim. Sci., v. 60, n. 2, p. $427-433,1985$.

JORGE, A. M.; FONTES, C. A. A.; PAULINO, M. F. Composição corporal de bovinos de quatro raças zebuínas, abatidos em diferentes estádios de maturidade. Rev. Bras. Zootec., v. 28, n. 2, p. 388-394, 1999.

KEARL, L. C. Nutrient Requirements of Ruminants in Developing Countries. International Feedstuffs Institute, Utah Agricultural Exp. Sta., Utah University, Logan, 271p, 1982.

KOONG, L. J.; FERREL, C. L.; NIENABER, J. A. Assessment of interrelationships among levels of intake and production, organ size and fasting heat production in growing animals. J. Nutr., Baltimore, v. 115, n. 10, p. 1383-1390, oct., 1985. 
KUNKLE, W. E.; HOPKINS, D. I. Is methionine the first limiting amino acid for growing cattle fed forages? In: Proccedings of $\mathbf{1 0}^{\mathrm{TH}}$ Annual Florida Nutrition Symposium, p. 19-29, University of Florida, Gainsville, 1999.

LADEIRA, M. M.; VALADARES FILHO, S. C.; COELHO da SILVA, J. F. Et al. Dietas contendo diferentes níveis de concentrado em novilhos Nelore: consumo e digestibilidade aparente total. In: REUNIÃO ANUAL DA SOCIEDADE BRASILEIRA DE ZOOTECNIA, 35, 1998, Botucatu. Anais...Botucatu: SBZ, p. 576, 1998.

LANA, R. P.; FONTES, C. A. A.; PERON, A. J. et al. Composição corporal e do ganho de peso e exigências de energia, proteína e macro elementos minerais ( $\mathrm{Ca}, \mathrm{P}, \mathrm{Mg}, \mathrm{Na}$ e $\mathrm{K}$ ), de novilhos de cinco grupos raciais. 2. Exigências de energia e proteína. Rev. Soc. Bras. Zoot., Viçosa, MG, v. 21, n. 3, p. 528-537, maio/junho, 1992.

LANÇANOVA, J. A. C. OLIVEIRA, M. D. S.; PACOLA, L. J.; et al. Digestibilidade aparente da matéria seca, matéria orgânica, e energia bruta e nutrientes digestíveis totais de uma ração completa para bovinos de diferentes grupos genéticos. Rev. Bras. Zootec., v. 30, n. 3, p. 897-903, 2001.

LANNA, D. P. D.; MORAIS, J. P.; BOIN, C.; et al. Desempenho e composição corporal de novilhas alimentadas com dois níveis de concentrado e bagaço de cana submetidos a diferentes processos de hidrólise. Rev. Bras. Zootec., v. 28, n. 2, p. 412-420, 1998a.

LANNA, D. P. D.; FOX, D. G.; TEDESCHI, L. O. Exigências nutricionais de gado de corte: O sistema NRC. Anais do Simpósio sobre Produção Intensiva Gado Corte - CBNA. p.138167, Campinas, Abril, 1998b.

LANNA, D. P. D. Fatores condicionantes e predisponentes da puberdade e da idade de abate. In: Simpósio sobre Pecuária de Corte, 4, Anais. FEALQ, Piracicaba. p.41-78, 1997a.

LANNA, D. P. D.; LEME, P. R.; BOIN, C.; et al Ganho compensatório de bovinos de diferentes grupos genéticos: composição química e física corporal. In: REUNIÃO DA SOCIEDADE BRASILEIRA DE ZOOTECNIA, 34, Juiz de Fora, Anais... ,Juiz de Fora, MG, p. 352 - 354, 1997b.

LANNA, D. P. D., BOIN, C., ALLEONI, G.F., LEME, P.R. Estimation of carcass and empty body composition of zebu bulls using the composition of rib cuts. Scientia Agricola, v. 52, n. 1, p. 189-197, 1995.

LANNA, D. P. D. Estimativa da composição química do corpo vazio de tourinhos Nelore através da gravidade específica da carcaça e da composição química de cortes das costelas. Piracicaba - SP, 131p., Dissertação. (Mestrado em Agronomia) - Escola Superior de Agricultura "Luiz de Queiróz", USP, 1988.

LAWRENCE, T. L. J.; FOWLER, V. R. Growth of farm animals. New York: CAB International. 330p. 1997.

LEDGER, H. P.; ROGERSON, A.; FREEMAN, G. H. Further studies on the voluntary food intake of Bos indicus, Bos taurus and crossbred cattle. Anim. Prod., Harlow, v. 12, n. 3, p. 425431, Aug., 1970.

LEME, P. R.; SILVA, S. L.; PEREIRA, A. S. C.; et al. Níveis de bagaço de cana-de-açúcar in natura em dietas com elevada proporção de concentrados para novilhos Nelore em confinamento. In: Reunion Latinoamericana de Producción Animal, 17, 2001. Anais: Habana/Cuba, 2001 (CD-Rom). 
LEME, P. R.; LANNA, D. P. D.; HENRIQUE, W.; et al. Substituição do grão de milho por polpa de citros em dietas com diferentes níveis de concentrado. 2. Taxas de deposição e composição química corporal. Rev. Bras. Zootec., v. 29, n. 3, p. 834-839, 2000.

LEME, P. R.; BOIN, C.; ALLEONI, G. F.; et al. Estimativa da composição química corporal de novilhos Nelore através do espaço de deutério. Rev. Soc. Bras. Zootec., v. 23, n. 3, p. 441452, 1994.

LIMA, F. C. Digestão total e parcial de energia e proteína em taurinos, zebuínos, seus mestiços e em bubalinos. Viçosa, MG: UFV, Imp. Univ., 120p. Tese. (Doutorado em Zootecnia) - Universidade Federal de Viçosa, 1986.

LIMA, M. L. P. Produção de leite de vacas mestiças em pastagens de capim elefante cv. Guaçu (Pennisetum purpureum Schum. cv. Guaçu) e capim tanzânia (Panicum maximum Jacq. Cv. Tanzânia). Tese de doutorado, Jaboticabal, 102 p., 02/2002.

LOBLEY, G. E.; CONNELL, A.; LOMAX, M. A. et al. The effect of nitrogen and protein supplementation on feed intake, growth, and digestive function of steers with different Bos Taurus genotypes when fed a low quality grass hay. Aust. J. Agric. Res., v. 46, n. 6, p. 1121, 1995.

LOFGREEN, G. P.; GARRET, W. N. A system for expressing net energy requeriments and feed values for growing and finishing beef cattle. J. Anim. Sci., Albany, NY, v. 27, n. 3, p. 793806, may, 1968.

LORENZONI, W. R.; CAMPOS, J.; GARCIA, J. A.; et al. Ganho de peso, eficiência alimentar e qualidade da carcaça de novillos búfalos, nelores, holandeses e mestiços holandês-zebu. Rev. Bras. Zootec, v. 15, n. 6, p. 486-497, 1986.

MACIEL, R. A. Introdução à raça Brangus e seu uso no Brasil Central. Pecuária de Corte, ano XII, n.105, 12/2000; 01/2001.

MEDEIROS, S. R. Efeito da substituição do bagaço de cana de açúcar autohidrolisado por sorgo na fermentação ruminal em bovinos, digestibilidade in vivo em ovinos e desempenho animal em bovinos em acabamento. Tese de mestrado, ESALQ/USP. Piracicaba, SP. 104p, 1992.

MERTENS, D. R. Regulation of forage intake. In: FAHEY JR., G. C. (Ed.) Forage quality, evaluation and utilization. Madison: American Society of Agronomy. p. 450-493, 1994.

MOORE, R. L.; ESSIG, H. N.; SMITHSON, L. F. Influence of breeds of cattle on ration utilization. J. Anim. Sci., v. 41, n. 1, p. 202-207, 1975.

NATIONAL RESEARCH COUNCIL - NRC. Nutrients requirements of beef cattle. 7 ed. Washington, D.C., 242 p. 1996.

NEUMAN, A. L. Beef cattle. University of Illinois. 883 p., 1977.

NOLAN, J. V. Nitrogen metabolism by ruminal microorganisms: current understanding and future perspectives. Aust. J. Agric. Res., v. 47, n. 2, p. 227-246, 1993.

OLIVEIRA, S. R.; COELHO da SILVA, J. F.; VALADARES FILHO, S. C. Et al. Desempenho de novilhos Nelore, não castrados, recebendo rações com vários níveis de concentrado. In REUNIÃO ANUAL DA SOCIEDADE BRASILEIRA DE ZOOTECNIA, 35, 1998, Botucatu. Anais...Botucatu: SBZ, p. 155, 1998. 
OLIVEIRA, M. A. T.; FONTES, C. A. A.; LANA, R. P.; et al. Consumo alimentar e digestibilidade de rações com dois níveis de concentrado em bovinos de cinco grupos genéticos. Rev. Soc. Bras. Zoot. v. 23, n. 4, p. 667-677, 1994.

ØRSKOV, E. R.; FRASER, C.; KAY, R. N. B. Dietary factors influencing the digestion of starch in the rumen and small and large intestine of early weaned lambs. Brit. J. Nutr. v. 23 p. 217, 1969.

OWENS, F. N.; GILL, D. R.; SECRIST, D. S. et al. Review of some aspects of growth and development of feedlot cattle. J. Anim. Sci., v. 73, p. 3152-3172, 1995.

OWENS, F. N.; DUBESKI, P.; HANSON, C. F. Factors that alter the growth and development of ruminants. J. Anim. Sci., v. 71, p. 3138-3150, 1993

PARDI, M. C.; SANTOS, L. F.; SOUZA, E. R.; SANTOS, J. C. A epopéia do zebu: um estudo zootécnico-econômico 1944/1994. Editora UFG, Goiânia, p. 126. 1996.

PATERSON, J. A.; BELYEA, R. L.; BOWMAN, J. P. et al. The impact of forage quality and supplementation regime on ruminant animal intake and performance. In: FAHEY JR., G. C. (Ed.). Forage quality, evaluation and utilization. Madison: American Society of Agronomy, p. 59-114, 1994.

PAULINO, M. F. Composição corporal e exigências de energia, proteína e macroelementos minerais ( $\mathrm{Ca}, \mathrm{P}, \mathrm{Mg}, \mathrm{Na}$ e $\mathrm{K}$ ) de bovinos de quatro raças zebuínas em confinamento. Viçosa, MG: UFV, 1996. 80p. Tese (Doutorado em Zootecnia) - Universidade Federal de Viçosa, 1996.

PETIT, H. V.; VEIRA, D. M.; YU, Y. Growth and carcass characteristics of beef steers fed silage and different levels of energy wth or without protein supplementation. J. Anim. Sci., v. 72, n. 6, p. 3221-3229, 1994.

PINEDA, N. R. Influência do Nelore na produção de carne no Brasil. In: Simpósio Nelore 2000. Anais... Ribeirão Preto-SP. p. 3-13. 2000.

PIRES, C. C.; FONTES, C. A. A.; GALVÃO, J. G. et al. Exigências nutricionais de bovinos de corte em acabamento. I. Composição corporal e exigências de proteínas para ganho de peso. Rev. Soc. Bras. Zoot., Viçosa, MG, v. 22, n. 1, p. 110-120, jan/fev., 1993a.

PIRES, C. C.; FONTES, C. A. A.; GALVÃO, J. G. et al. Exigências nutricionais de bovinos de corte em acabamento. II. Exigências de energia para mantença e ganho de peso. Rev. Soc. Bras. Zoot., Viçosa, MG, v. 22, n. 1, p. 121-132, jan/fev., 1993b.

PITTS, J. S.; MCCOLLUM, F. T.; BRITTON, C. M. Protein supplementation steers grazing tobosa-grass in spring and summer. Journal Of Range Management, v. 45, p. 226-231, 1992.

RATTRAY, P. V.; JOYCE, J. P. Utilization of metabolisable energy for fat and protein deposition in sheep. N. Z. Journal of Agricultural Research, Wellington, NZ, v. 19, n. 3, p. 299-305, aug., 1976.

REID, J. I.; WHITE, D.; ANRIQUE, R. et al. Nutritional energetics of livestock; some present boundaries of knowledge and future research needs. J. Anim. Sci., Albany, NY, v. 51, n. 6, p. 1393-1415, dec., 1980.

RESENDE, F. D.; QUEIROZ, A. C.; OLIVEIRA, J. V.; et al. Bovinos mestiços alimentados com diferentes proporções de volumoso:concentrado. 1. Digestibilidade aparente dos nutrientes, ganho de peso e conversão alimentar. Rev. Bras. Zootec, v. 30, n. 1, p. 261-269, 2001. 
ROBELIN, J.; GEAY, Y. Body composition of cattle as affected by physiological status, breed, sex and diet. Herbivore nutrition in the subtropics and tropics. p. 525-547, 1984.

RODE, L. M.; WEAKLEY, D. C.; SATTER, L. D. Effect of forage amount and particle size in diets of lactating dairy cows on site of digestion and microbial synthesis. Can. J. Anim. Sci., v. 65, n. 1, p. 101-111, 1985.

RODRÍGUEZ, L. R. R.; FONTES, C. A. A.; JORGE, A. M. et al. Digestibilidade de rações contendo quatro níveis de concentrado, em bovinos (taurinos e zebuínos) e bubalinos. Rev Bras. Zoot., v. 26, n. 4, p. 844-851, 1997.

RODRÍGUEZ, L. R. R.; FONTES, C. A. A.; JORGE, A. M,; et al. Consumo de rações contendo quatro níveis de concentrado por bovinos holandeses e nelore e por bubalinos. Rev. Soc. Bras. Zootec., v. 25, n. 3, p. 568-581, 1996.

ROHR, K.; DAENICKE, R. Nutritional effects on the distribuition of live weight as gastrointestinal tract fill and tissue components in growing cattle. J. Anim. Sci., Albany, NY, v. 58, n. 3, p.753-765, mar., 1984.

SALOMONI, E.; TIESENHAUSEN, I. M. E. V.; PEREIRA, E. A. Níveis de energia na terminação de novilhos "azebuados" em confinamento. In: REUNIÃO ANUAL DA SOCIEDADE BRASIELEIRA DE ZOOTECNIA, 17, 1980, Fortaleza. Anais... Fortaleza: SBZ, p. 43, 1980.

SALVADOR, M.; COELHO da SILVA, J. F.; GARCIA, J. A.; et al. Composição do corpo, composição do ganho de peso e exigências de proteína e energia para engorda de novilhos azebuados. III. Exigências de proteína e energia para engorda de novilhos azebuados. Rev. Soc. Bras. Zoot., Viçosa, MG, v. 10, n. 2, p. 195-211, 1981.

SANTIAGO, A. A. O Nelore. Ed. dos Criadores. p. 39, 1983.

SAS / Start User's Guide Version 6. 4ed, v.2, Cary, North Carolina. SAS Institute Inc., 1989.

SHAHIN, K. A.; BERG, R. T.; PRICE, M. A. The effect of breed-type and castration on tissue growth patterns and carcass composition in cattle. Livest. Prod. Sci., Amsterdam, v. 35, n. 3/4, p.251-264, jun. 1993.

SIGNORETTI, R. D.; COELHO DA SILVA, J. F.; VALADARES FILHO, S. C.; et al. Consumo e digestibilidade aparente, em bezerros holandeses alimentados com dietas contendo diferentes níveis de volumoso. In: REUNIÃO ANUAL DA SOCIEDADE BRASILEIRA DE ZOOTECNIA, 35, 1998, Botucatu, SP, Anais... Botucatu: SBZ, p. 422-424, 1998.

SIGNORETTI, R. D.; COELHO DA SILVA, J. F.; VALADARES FILHO, S. C.; et al. Composição corporal e exigências líquidas de energia e proteína de bezerros da raça holandesa alimentados com dietas contendo diferentes níveis de volumoso. Rev. Bras. Zootec., v. 28, n. 1, p. 195-204, 1999.

SILVA, D. J. Análise de alimentos (Métodos químicos e biológicos). Ed. UFV. Viçosa: Universidade Federal de Viçosa, 1998. 166p.

TAYLOR, St. C. S.; THIESSEN, R. B.; MURRAY, J. Interbred relationship of maintenance efficiency to milk yield in cattle. Anim. Prod., Harlow, v. 43, n. 1, p.37-61, Aug. 1986.

TEDESCHI, L. O.; BOIN, C.; FOX, D. G.; et al. Energy requirement for maintenance and growth of Nelore bulls and steers fed high-forage diets. J. Anim. Sci., v. 80, p. 1671-1682, 2002.

TEIXEIRA, J. C.; COELHO da SILVA, J. F.; GARCIA, J. A. et al. Exigências de energia e proteína, composição e área corporal e principais cortes da carcaça em seis grupos genéticos de bovídeos. II. Exigências de energia e proteína. Rev. Soc. Bras. Zoot., Viçosa, MG, v. 16, n. 2, p. 182-192, mar./abr., 1987. 
THORBEK, G. Studies on protein and energy metabolism in growing calves. Beretn. ForØgslab. No 498. 1980

TIBO, G. C.; VALADARES FILHO, S. C.; VALADARES, R. F. D.; et al. Níveis de concentrado em dietas de novilhos mestiços F1 Simental X Nelore. 1. Consumo e digestibilidades. Rev. Bras. Zootec., v. 29, n. 3, p. 910-920, 2000.

TYRREL, H. F.; MOE, P. W.; OLTJEN, R. R. Energetics of growth and fattening compared to lactation in cattle. Proc. $6^{\text {th }}$ Symp. On Energy Metab. European Assoc. Anim. Prod. Pub. 14. p205-208. Stuttgart, F. R. Germany. 1974

VALADARES, R. F. D.; VALADARES FILHO, S. C.; GONÇALVES, L. C.; et al. Níveis de proteína em dietas de bovinos. 4. Concentrações de amônia ruminal e uréia plasmática e excreções de uréia e creatinina. R. Bras. Zootec., v. 26, n. 6, p. 1270-1278, 1997.

VALADARES FILHO, S. C. Digestão pós-ruminal de proteínas e exigências de aminoácidos para ruminantes. In: TEIXEIRA, J. C. (Ed). Simpósio Internacional de Digestibilidade em Ruminantes, 1997, Lavras, MG. Anais... Lavras: FAEPE. p. 87 - 113, 1997.

VALADARES FILHO, S. C.; COELHO da SILVA, J. F.; LEÃO, M. I. Estudo comparativo da digestão de matéria seca e carboidratos em bovinos e bubalinos alimentados com diferentes rações. Rev. Soc. Bras. Zootec, v. 16, n. 2, p. 120-130, 1987.

VALADARES FILHO, S. C; COELHO da SILVA, J. F.; LEÃO, M. I. et al. Digestão total e parcial da matéria seca e carboidratos em bovídeos alimentados com duas proporções de volumoso:concentrado (60:40 e 40:60\%). 2- Silagem de sorgo. Rev. Soc. Bras. Zoot., Viçosa, v. 14, n. 5, p. 587-598, set., 1985.

VAN KESSEL, J. S.; RUSSEL, J. B. The effect of amino nitrogen on the energetics of ruminal bacteria and its impact on energy spilling. Journal Dairy Science, v. 79, p. 1237-1243, 1996.

VAN SOEST, P. J. Nutritional ecology of the ruminants. 2 ed. London:Constock Publishing Associates, USA. 476p. 1994.

VÉRAS, A. S. C.; VALADARES FILHO, S. C.; COELHO da SILVA, J. F. et al. Predição da composição corporal e dos requisitos de energia e proteína para ganho de peso de bovinos, não castrados, alimentados com rações contendo diferentes níveis de concentrado. Rev. Bras. Zootec., v. 30, n. 3. p. 1127-1134, (Supl.1), 2001.

VÉRAS, A. S.C. ; VALADARES FILHO, S. C. ; COELHO da SILVA, J. F. et al. Composição corporal e requisitos energéticos e protéicos de bovinos Nelore, não-castrados, alimentados com rações contendo diferentes níveis de concentrado. Rev. Bras. Zootec., v. 29, n. 6, p. 2379-2389, 2000.

VERMOREL, M.; BICKEL, H. Utilisation of feed energy by growing ruminants. In: C. Béranger (Ed.) Energy and Protein Feeding Standards Applied to the Rearing and Finishing of Beef Cattle p.127-144. Ann. Zootechnie 29, No.h.s. 1980

VIACAVA, C.; CASTANHO FILHO, E. P.; PIRES, G.; et al. Nelore - O boi ecológico que está conquistando o mundo. Ed. Peirópolis, SP. p. 39-44. 2000.

WALDO, D. R.; GLEN, B. P. Foreign systems for meeting the protein requirements of ruminants. II. Meeting protein requirements of cattle. In: OWENS, F. N. (Ed). Proc. Protein requirements for cattle: Symposium, 109, p.269-309, 1981.

WEBSTER, A. J. F. Bioenergetics, bioengineering and growth. Animal Production. V.48, p.249269, 1989. 